\title{
Primary Prevention of Colorectal Cancer
}

\author{
Andrew T. Chan, MD, MPH and Edward L. Giovannucci, MD, ScD \\ Gastrointestinal Unit, Massachusetts General Hospital and Harvard Medical School (ATC); \\ Channing Laboratory, Brigham and Women's Hospital and Harvard Medical School (ATC and ELG); \\ Departments of Nutrition and Epidemiology, Harvard School of Public Health (ELG)
}

\section{Abstract}

Colorectal cancer has been strongly associated with a Western lifestyle. In the past several decades, much has been learned about the dietary, lifestyle, and medication risk factors for this malignancy. Although there is controversy about the role of specific nutritional factors, consideration of the dietary pattern as a whole appears useful for formulating recommendations. For example, several studies have shown that high intake of red and processed meats, highly refined grains and starches, and sugars is related to increased risk of colorectal cancer. Replacing these factors with poultry, fish, and plant sources as the primary source of protein; unsaturated fats as the primary source of fat; and unrefined grains, legumes and fruits as the primary source of carbohydrates is likely to lower risk of colorectal cancer. Although a role for supplements, including vitamin D, folate, and vitamin B6, remains uncertain, calcium supplementation is likely to be at least modestly beneficial. With respect to lifestyle, compelling evidence indicates that avoidance of smoking and heavy alcohol use, prevention of weight gain, and the maintenance of a reasonable level of physical activity are associated with markedly lower risks of colorectal cancer. Medications such as aspirin and nonsteroidal anti-inflammatory drugs and post-menopausal hormones for women are associated with significant reductions in colorectal cancer risk, though their utility is affected by associated risks. Taken together, modifications in diet and lifestyle should substantially reduce the risk of colorectal cancer and could complement screening in reducing colorectal cancer incidence.

\section{Introduction}

In the United States, colorectal cancer is the third leading cause of cancer death in each sex and second overall in men and women combined. In 2009, an estimated 146,970 men and women will be newly diagnosed with colorectal cancer; 49,920 deaths will be attributable to the disease. At current rates, approximately $5 \%-6 \%$ of individuals will develop a cancer of the colon or rectum within their lifetime. ${ }^{1}$ Before the 1900 s, colorectal cancer was relatively uncommon in the U.S., but its incidence rose dramatically over the last century in parallel with economic development. Worldwide, the majority of colorectal cancers continue to occur in industrialized countries, although incidence rates are rapidly rising in less-developed nations

(C) 2010 The American Gastroenterological Association. Published by Elsevier Inc.

Correspondence to: Andrew T. Chan, M.D., M.P.H., Gastrointestinal Unit, Massachusetts General Hospital, 55 Fruit Street, GRJ-722, Boston, MA 02114, Tel: 617726 3212, Fax: 617726 3673, achan@partners.org .

Publisher's Disclaimer: This is a PDF file of an unedited manuscript that has been accepted for publication. As a service to our customers we are providing this early version of the manuscript. The manuscript will undergo copyediting, typesetting, and review of the resulting proof before it is published in its final citable form. Please note that during the production process errors may be discovered which could affect the content, and all legal disclaimers that apply to the journal pertain.

Financial Disclosures: No conflicts of interest exist.

Author Contributions: Each author was directly involved with drafting of the manuscript; critical revision of the manuscript for important intellectual content; obtaining funding. 
as they increasingly adopt features of a Western lifestyle. ${ }^{2}$ Migration studies also demonstrate a higher lifetime incidence of colorectal cancer among immigrants to high-incidence, industrialized countries compared to residents remaining in their native, low-incidence countries. Taken together, these data highlight the importance of environmental influences on colorectal carcinogenesis. ${ }^{3}$

In this review, we provide an overview of the epidemiological evidence supporting the roles of diet, lifestyle, and medication use in colorectal cancer risk. Moreover, we focus on those risk factors that are potentially modifiable, including overall dietary patterns, avoidance of smoking, excessive alcohol, weight gain, maintenance of a reasonable level of physical activity, and use of aspirin. The cornerstones of colorectal cancer prevention are screening and detection of adenomatous polyps. However, improving our understanding of the modifiable risk factors might inform additional primary prevention strategies that can further reduce risk. ${ }^{4}$ In addition, because many of the diet and lifestyle characteristics that are related to colorectal carcinogenesis appear to be important for other major chronic diseases, adopting the appropriate changes to these risk factors are likely to improve overall health.

\section{DIET}

\section{Fruit, Vegetables, and Fiber}

The concept that a diet that is high in fiber, especially from fruits and vegetables, lowers risk of colorectal cancer has been in existence for more than 4 decades, following the observation of the relative rarity of colorectal cancers in African populations that consume a high-fiber diet. $^{5}$ Fiber has been proposed to dilute or adsorb fecal carcinogens, modulate colonic transit time, alter bile acid metabolism, reduce colonic $\mathrm{pH}$, or increase the production of short-chain fatty acids. ${ }^{6}$ Subsequently, the relation between colorectal cancer and fiber, as well as fruits and vegetables more generally, has been evaluated in case-control and cohort studies. The majority of case-control studies have shown an association between higher intake of fiber, vegetables, and possibly fruits, and lower risk of colon cancer. ${ }^{7}$ A meta-analysis of 6 such casecontrol studies found that a high intake of vegetables or fiber was associated with an approximate $40 \%$ to $50 \%$ reduction in risk for colon cancer. ${ }^{8}$ Similarly, a pooled analysis of 13 case-control studies reported an approximately $50 \%$ lower risk of colon cancer associated with higher intake of fiber. ${ }^{9}$

However, as case-control evidence for the fiber hypothesis appeared to be consolidating, results from large prospective cohort studies emerged that showed a nonexistent or weak association between dietary fiber intake and colon cancer.4 ${ }^{1} 10^{-} 12$ In data from a prospective study conducted among the female U.S. nurses enrolled in the Nurses' Health Study (NHS), we found that a high-fiber diet, measured by a semi-quantitative validated food frequency questionnaire, did not protect against colorectal cancer or adenoma. Furthermore, no associations were observed with specific subtypes of fiber, including cereal, fruit, or vegetable fiber or subtypes of cancer by location or stage. $13 \mathrm{We}$ also found null results in a detailed analysis of fruit and vegetable intake and colorectal cancer risk in this cohort.14 Similarly, in a Finnish population with a wider range of fiber intakes ( 16.0 to $34.1 \mathrm{~g} /$ day between the lowest and highest quartiles), an inverse association between colorectal cancer and total fiber intake was not seen.15 Recently, a pooled analysis of 13 prospective cohorts including over 700,000 participants did show a modest, inverse association between fiber intake and colorectal cancer. However, after accounting for other dietary risk factors, this association was no longer significant, suggesting that high fiber intake might simply have been correlated with other protective lifestyle or dietary factors.16 A pooled analysis of fruit and vegetable intake also failed to detect an association with overall colorectal cancer risk.17 
The reasons for the apparent inconsistencies between the encouraging results from case-control studies and the largely null findings of cohort studies are not entirely clear. However, casecontrol studies may be more prone to bias because dietary information was collected after the diagnosis of cancer and individuals with cancer are more likely to recall perceived unhealthy dietary behaviors. Of note, a recent prospective study of over 500,000 individuals from 10 European populations (the EPIC study) did show an approximately $40 \%$ reduced risk of colorectal cancer among individuals with the highest intake of fiber.18 Similarly, in this population, high intake of fruit and vegetables was associated with a modest reduction in colorectal cancer risk.19 The reason for the discordance between the inverse association found between fiber and colorectal cancer in the European studies and the lack of association in other cohort studies that were primarily conducted in the U.S. might be related to differences in intake of other nutrients such as folate; folate could have anti-cancer effects (see section on B vitamins). In the U.S., the high prevalence of use of folate-containing multivitamins and the folate fortification of flour and breakfast cereals, (at least since 1998 when fortification became mandatory), might attenuate any additional effects of high-fiber fruits and vegetables, the primary source of these folate in the European populations. So, whereas fruits, vegetables, and fiber might influence colorectal cancer risk, these effects, if present, are likely to be much weaker than previously believed or may only be evident among individuals with extremely low baseline levels of intake

To specifically address the role of fiber and vegetables in cancer prevention, several randomized, placebo-controlled intervention trials of fiber supplementation on risk of recurrent adenomas among individuals with a prior history of adenoma have been conducted. Diets with large amounts of fruits and vegetables, ${ }^{20}$ wheat bran fiber supplements, ${ }^{21}$ or ispaghula fiber supplements, ${ }^{22}$ were each found to have no effect on the risk of recurrent adenoma. In fact, ispaghula husk was associated with an unexpected increased risk of adenoma. Although it has been proposed that these trials were null due to an inadequate dose of fiber, it is unlikely that larger amounts would be well tolerated. For example, in the wheat bran supplement trial, only $74 \%$ of the high-fiber group consumed more than $75 \%$ of their supplement compared to $84 \%$ of the low-fiber group. Thus, daily, long-term consumption of higher levels of fiber probably would be impractical in the general population. ${ }^{21}$ These data, when viewed in the context of most prospective epidemiologic studies, raise questions about not only the ability of fiber supplements to reduce risk of colorectal cancer but the feasibility of such an approach.

Finally, resistant starch has been hypothesized to have specific anti-cancer properties since this form of fiber is preferentially fermented into potentially beneficial short-chain fatty acids in the colon. In preclinical models, animals fed resistant starch have a lower incidence of intestinal tumors. ${ }^{23}$, 24 In humans, resistant starch reduces cell proliferation in the upper part of the colonic crypts, 25 and some epidemiological studies have supported an inverse association between resistant starch intake and colorectal neoplasia.26 However, a recent multi-center randomized control trial of resistant starch at a dose of $30 \mathrm{~g} /$ day conducted among European individuals with Lynch syndrome failed to observe a significant reduction in risk of neoplasia after 4 years of follow-up. ${ }^{27}$ Although higher amounts of resistant starch could conceivably be required to observe a protective effect, this dose of resistant starch was already more than three times higher than typical intake. Moreover, the overall compliance rate for this level of intake was already limited (77\%), again suggesting that higher dosing may not be feasible. Longer term follow-up and further studies of resistant starch among patients without Lynch syndrome are needed.

In summary, increasing intake of fruits, vegetables, or fiber is unlikely to prevent a large proportion of colorectal cancers, particularly among a U.S. population, which has a food supply already fortified with folate and other dietary factors that might protect against colorectal neoplasia. There is also little evidence that concentrated sources of one type of fiber are 
efficacious, though fiber-rich diets have health benefits for other gastrointestinal conditions such as diverticular disease and constipation and possibly other chronic diseases.

\section{Red Meat, Fat, and Carbohydrates}

The effects of red meat (e.g. beef, pork, or lamb) have been examined in many epidemiologic studies; most, though not all, associate an increase in colon cancer or adenoma risk with greater intake of red meat.10-12, $28^{-} 44$ In a prospective study of a cohort of U.S. male health professionals, the Health Professionals Follow-up Study (HPFS), we found that men who ate beef, pork, or lamb as a main dish more than 5 times a week had a 3-fold increase in risk of colon cancer, compared with men who ate these meats less than once a month. ${ }^{4}$ Additional studies have also associated processed meats with risk.40, 45-47 In the EPIC study population, the absolute risk of developing colorectal cancer within 10 years for a 50 year old participant was $1.71 \%$ for the highest category of red and processed meat intake compared with $1.28 \%$ for the lowest category of intake. ${ }^{40}$ The specific mechanisms that underlie the association between red meat and colorectal cancer are unclear. Red meat might stimulate secretion of endogenous insulin, which is a mitogen (see section on body mass index) (Figure 1). Other relevant hypotheses include red meat as a major source of total or saturated fat, heme iron, or carcinogenic heterocyclic amines. In general, neither case-control or prospective studies have supported a specific association between fat and colorectal cancer. ${ }^{4,}{ }^{10-12}$ Although some early studies had indicated an association between heme iron and colorectal cancer, ${ }^{48-51}$ other studies have not produced consistent results. ${ }^{5-54}$ In the NHS, prospective assessments of dietary iron intake as well as several biochemical measures of iron status indicated that iron levels were not associated with colorectal adenoma. ${ }^{55}$

Evidence indicates that the association between red meat and colorectal cancer might be related to the cooking process. Several studies have found that risk of colon cancer is specifically increased among meat eaters who consume meat with a heavily browned surface or meat that has been prepared at high temperatures at prolonged durations. ${ }^{34,38,56,57}$ When meat undergoes prolonged frying, grilling, or broiling at high temperatures, mutagenic heterocyclic amines are formed from creatinine, and these interact with amino acids. ${ }^{58-60}$ Specific analyses focused on intake of heterocyclic amines, estimated using dietary indices of meat-associated mutagens, have associated the heterocyclic amines with colorectal adenoma or cancer. ${ }^{38,61-}$ ${ }^{69}$ In the HPFS, higher consumption of these mutagens was associated with adenoma of the distal colon, independent of total overall meat intake. ${ }^{70}$ Similarly, heterocyclic amines, measured using urine or leukocyte assays, have been associated with adenoma in other populations. ${ }^{71,72}$ Finally, studies examining interactions between meat intake, cooking methods, and genetic polymorphisms that modulate metabolism of heterocyclic amines also provide indirect, yet compelling support for an association between these carcinogens and colorectal neoplasia. $64^{-} 66,73^{-80}$ For example, in the NHS, women with genotypes associated with rapid acetylation of meat-associated carcinogens had a particularly high risk of colorectal cancer that was associated with red meat intake (multivariate hazard ratio [HR], 3.01; 95\% confidence interval [CI], 1.10-8.18). In contrast, women with genotypes associated with slow acetylation did not have a significantly higher risk of cancer with increased red meat intake (multivariate HR, 0.87; 95\% CI, 0.35-2.17). ${ }^{81}$ Alternative sources of animal protein, including low-fat dairy products, fish, and poultry, have been associated with reduced risk of colon cancer or adenoma, compared with that of red meat, in most, but not all studies.4, $10^{-} 12,29,30,39$, 82, 83 These results do not support an overall adverse effect of protein intake on cancer risk, and even suggest a reduction in risk. The mechanism that underlies this reduction is unknown, but these foods are good sources of methionine, which could improve the regulation of DNA methylation. In addition, some, but not all, studies have associated sources of animal protein, especially fish, that are high in $n-3$ fatty acids with reduced risk of colorectal cancer. ${ }^{40,}$, $4-$

${ }^{88}$ Recent data from a large prospective U.S. cohort suggested either a weak or non-existent 
association, with a possible differential effect according to sex. Intake of marine $n$-3 fatty acids was not associated with colorectal cancer risk among men, but was modestly associated with lower risk among women. However, even this benefit was attenuated after adjustment for other risk factors. ${ }^{89} \mathrm{~A}$ similar potential sex difference was also suggested in a meta-analysis of studies examining fish intake and risk of colorectal cancer ${ }^{84}$ Multiple animals and in vitro studies have shown that $n-3$ fatty acids reduce inflammation, 90 disrupt activity of the nuclear factor$\kappa \mathrm{B}(\mathrm{NF}-\kappa \mathrm{B})$ and cyclooxygenase-2 (COX-2), competitively inhibit arachidonic acid metabolism, and induce 15-prostaglandin dehydrogenase (15-PGDH), a physiological COX-2 antagonist.87, 91, 92 Each of these mechanisms could retard carcinogenesis (see section on aspirin and NSAIDs) (Figure 2). In summary, limiting intake of processed meat and red meat, especially after high-temperature cooking, and replacing these foods with poultry or fish as alternative protein sources could be a reasonable approach to reducing risk of colorectal cancer.

Beyond fats and proteins, there is some evidence associating intake of highly refined carbohydrates with colorectal cancer.12, 93, 94 Intake of highly refined carbohydrates stimulates short-term surges of insulin secretion, which might stimulate colonic carcinogenesis (see section on body mass index) (Figure 1). Some studies have associated diets with a high glycemic load or glycemic index with risk of colorectal adenoma or cancer. ${ }^{95-99}$ However, many other studies have failed to confirm these associations. ${ }^{100-107}$

\section{Calcium and Vitamin D}

Calcium has been proposed to reduce risk of colorectal cancer by binding to toxic secondary bile acids and ionized fatty acids to form insoluble soaps in the lumen of the colon, ${ }^{108,109}$ or by directly reducing proliferation, stimulating differentiation, and inducing apoptosis in the colonic mucosa. ${ }^{10-112}$ Large prospective studies have consistently shown a modest and significant inverse association between calcium intake and colorectal cancer risk. ${ }^{113}$ In an analysis of cases from the NHS and HPFS, total, dietary and supplemental calcium reduced the risk of distal colon cancer but not of proximal colon cancer. ${ }^{114}$ Notably, most of the risk reduction was achieved by attaining intakes of 700 to $800 \mathrm{mg} / \mathrm{day}$, which suggests a threshold level above which further calcium would not be beneficial. In a recent analysis that pooled the results of 10 large, prospective cohort studies, those in the highest quintile of calcium intake had a $22 \%$ reduction in risk of colorectal cancer, compared to those in the lowest quintile. ${ }^{115}$

The findings from observational studies have been confirmed in randomized, placebocontrolled trials conducted among patients with a history of adenoma. Results of an intervention trial of calcium supplementation (1200 mg of elemental calcium vs. placebo) among 913 participants found a moderate but statistically significant reduction in risk of recurrent adenoma at 4 years; the rate of new adenomas was 31\% among those assigned calcium and 38\% among those assigned placebo.116 In subsequent analyses, the benefit was most pronounced for advanced adenoma, with a risk ratio of 0.65 (95\% CI, 0.46-0.93) compared to placebo, 117 and the effect of calcium persisted for at least 5 years after cessation of treatment.118 Moreover, the protective effect of calcium appeared entirely limited to those with higher 25-hydroxy-[25$(\mathrm{OH})]$ vitamin D levels.119 Similar results were observed for $2 \mathrm{~g}$ elemental calcium daily versus placebo in a European trial, although the result was not statistically significant in this relatively small study. 22

In 1980, Garland and Garland proposed that lower levels of vitamin D, resulting from reduced solar ultraviolet-B radiation exposure, could account for the increase in mortality from colon cancer among populations at higher latitudes. ${ }^{120}$ Vitamin D could reduce risk of colorectal cancer through various mechanisms, including reducing cell proliferation, inhibiting angiogenesis, promoting cell differentiation, and stimulating apoptosis. ${ }^{110,111,121}$ Increasing data also indicate an anti-inflammatory mechanism (Figure 2). In animal models of colitis, deficiency of the vitamin D receptor resulted in severe inflammation, ${ }^{122,}{ }^{123}$ whereas vitamin 
D supplements inhibited colitis and COX-2 expression. ${ }^{124-126}$ In humans, polymorphisms in the vitamin D receptor and vitamin D deficiency have been associated with inflammatory bowel disease, $127^{-} 131$ gingival inflammation, 132 and periodontal disease, a marker for chronic inflammation. ${ }^{133}$ Vitamin D supplements were also associated with a dose-dependent decrease in the inflammatory marker C-reactive protein (CRP) in an intervention study.134 It is not clear whether the actions of vitamin D require calcium; calcium-dependent and calcium-independent mechanisms have been proposed.110,111, 119 Several prospective studies have examined circulating levels of 25(OH)-D and found an inverse association with rectal cancer,135 colorectal cancer, or adenoma. 119, 136-143 In a meta-analysis of these studies, based on 535 colorectal cancer cases, individuals with serum levels of $25(\mathrm{OH}) \geq 33 \mathrm{ng} / \mathrm{mL}(82 \mathrm{nmol} / \mathrm{L})$ had $50 \%$ lower incidence of colorectal cancer $(\mathrm{p}<0.01)$ than individuals with levels less than 12 $\mathrm{ng} / \mathrm{mL}(30 \mathrm{nmol} / \mathrm{L}) .144$ The 2 largest studies included in the meta-analysis were from the NHS and the Women's Health Initiative (WHI), a randomized placebo-controlled trial of $400 \mathrm{IU}$ vitamin D plus $1000 \mathrm{mg} /$ day of calcium in 36,282 post-menopausal women. The NHS study showed, based on 193 incident cases of colorectal cancer, that the relative risk of colorectal cancer decreased linearly across quintiles of plasma $25-(\mathrm{OH})$ vitamin D concentration, with a $47 \%$ risk reduction for the highest compared to the lowest quintile.137 Similarly, in the WHI study, an inverse association was observed between baseline levels of $25-(\mathrm{OH})$ vitamin D and colorectal cancer risk.143

However, the results of the WHI study did not support a protective role of the calcium and vitamin D intervention on colorectal cancer risk over a follow-up period of 7 years.

Nonetheless, this trial had some important limitations. First, the vitamin D dose of $400 \mathrm{IU} / \mathrm{day}$ was probably inadequate to yield a substantial contrast between the group given vitamin $\mathrm{D}$ and the group given placebo. Specifically, the expected increase in serum levels of $25-(\mathrm{OH})$ vitamin D following an increment of $400 \mathrm{IU} /$ day would be approximately $3 \mathrm{ng} / \mathrm{ml}$. In comparison, in the epidemiologic studies of $25-(\mathrm{OH})$ vitamin $\mathrm{D}$, the difference between the highest and lowest quintiles was at least $20 \mathrm{ng} / \mathrm{mL}$. Second, for the calcium intervention, most of the women also had baseline calcium intakes of more than $1000 \mathrm{mg} /$ day, exceeding the threshold for a benefit based on the observational studies. Third, 7 years of follow-up might have been insufficient to show an effect on cancer incidence. The epidemiologic data on duration, although limited, indicate that any influence of calcium and vitamin D intake on colorectal cancer risk could require at least 10 years to emerge. ${ }^{145}$ Finally, the WHI study had a factorial design and also examined a hormone replacement intervention. In a post-hoc analysis, we found that women that were randomly assigned to the group that was given hormones did not have a lower risk of colorectal cancer from vitamin D and calcium, whereas women who did not take hormones did benefit. 146

In summary, data support a significant, yet modest ability of calcium intake to prevent colorectal cancer. The precise mechanism by which vitamin D prevents colorectal cancer is not clear, but future randomized control trials of higher doses of vitamin D might provide more information. Although an association between colorectal cancer and vitamin $\mathrm{D}$ has not been definitively proven, it is important to achieve a level of at least $30 \mathrm{ng} / \mathrm{mL}$, since this dose has been shown to be optimal for other health conditions.

\section{B Vitamins}

B vitamins are integral components of one-carbon metabolism, which affects processes that influence cancer risk such as DNA synthesis, repair, and methylation. Based on this premise, B vitamins, particularly folate and vitamin B6, have been studied in relation to risk of colorectal cancer. Folate has received most attention. Studies that have examined folate intake in relation to risk of colorectal cancer or adenoma have largely shown that higher intakes are typically associated with reduced risk.147 Specifically, one meta-analysis found an association with 
dietary folate but not with folate from supplements. 148 This finding suggests either that correlated factors other than, or in combination with folate are the truly protective factors, or that the form of folate administration could influence its effectiveness. Consistent with experimental data that folate deficiency may induce p53 mutations, low dietary folate has also been specifically associated with increased risk of colorectal cancers with p53 mutations but not wild-type tumors. ${ }^{149}$ Also relevant to the folate hypothesis is the role of methylenetetrahydrofolate reductase (MTHFR), an enzyme at a critical metabolic branch point that directs the folate pool towards remethylation of homocysteine to methionine at the expense of thymidylate synthesis. A functionally variant form of MTHFR has been consistently associated with risk of colorectal cancer, especially when considered in conjunction with intakes of folate or alcohol. ${ }^{147}, 150$ The finding with MTHFR tends to add further credence of a biologic role for folate in colorectal carcinogenesis (Figure 3).

This observational data and the supporting mechanistic evidence provided the impetus to conduct several randomized controlled trials of folic acid (the synthetic form of folate) in relation to risk of subsequent adenomas in individuals with a history of adenoma. In contrast with the observational studies, these trials tended not to support a benefit of folic acid given at $0.5 \mathrm{mg}$ or $1 \mathrm{mg}$ daily. $151,152 \mathrm{In}$ fact, one trial suggested a possible increased risk of recurrent advanced adenoma or multiple adenomas related to excessive folate. 153 These studies indicate that an additional supplement of folic acid is unlikely to be beneficial, and even harmful, for those who already have had a colonic neoplasm. However, the effect of folic acid may differ among individuals with baseline folate deficiency. In our recent randomized trial, although folic acid supplementation was not associated with overall reduction in risk of recurrent adenoma, participants with low plasma folate concentrations at baseline did experience a significant decrease in adenoma recurrence (RR, $0.61 ; 95 \%$ CI: $0.42,0.90) .152$ It is also possible that future studies may suggest a role for measuring baseline plasma folate levels prior to use of folate supplementation. The timing of supplementation may also be a key determinant of its effect on neoplasia. Studies from animal models have shown that adequate dietary folate can suppress initial tumor formation, but excess folate during later stages of carcinogenesis could promote carcinogenesis. 154 Taken together with observations that methylation patterns can be altered even in the apparently normal mucosa of patients with tumors, there could be a preexisting "field defect" in the colonic mucosa of patients with prior adenoma that folic acid is unable to reverse. 155 Finally, there is evidence that more than a decade would be required to observe any preventative effects of folate on colorectal carcinogenesis-this time period exceeds that of short-term randomized trials to monitor development of adenoma. In summary, most individuals should receive the recommended $400 \mu \mathrm{g} / \mathrm{day}$ of folate, but it is not clear whether higher doses are beneficial or harmful with respect to colorectal cancer prevention. Due to food fortification in the U.S., few in the U.S. are folate deficient; however, folatedeficient populations, particularly those without a prior history of neoplasia, could benefit from supplements to prevent colorectal cancer.

Only in the past several years has the association between vitamin B6 and risk of colorectal cancer received adequate study. Vitamin B6 is involved in many cellular functions, so it could have anti-cancer mechanisms beyond its role in one-carbon metabolism. Remarkably, most studies have associated higher intake of vitamin B6 or higher levels of pyridoxal 5'-phosphate (PLP), the main circulating form of B6, with a 30\%-40\% decrease in risk of colorectal cancer. ${ }^{156-} 162$ In many of the studies, the inverse association between vitamin B6 and colorectal cancer was even stronger than that observed for folate; the decrease in risk might be greatest among individuals with heavy intake of alcohol. Dietary B6 intake may also be preferentially associated with risk of colorectal cancers with p53 mutations. 149 Of note, there is some data which suggest that vitamin B6 increases risk for rectal cancer.163 Clearly, interventional studies are required to clarify whether vitamin B6 does reduce the incidence of colorectal 
cancer. In summary, based on current evidence, it is not recommended that intake of vitamin B6 be increased to prevent colorectal cancer.

\section{Antioxidants and Other Micronutrients}

Several other dietary micronutrients, including selenium, beta carotene, and vitamins A, C, and $\mathrm{E}$ are believed to have anti-carcinogenic effects, based on their anti-oxidant or antiinflammatory properties and findings from observational studies. ${ }^{82,}$ 94, 164-168 Perhaps the strongest relationships have been observed with selenium. With a few exceptions, ${ }^{169,}{ }^{170}$ most studies have demonstrated an inverse association between colorectal adenoma and selenium levels, measured from toenail or plasma samples.171-177 Moreover, a remarkable, statistically significant, $50 \%$ reduction in colorectal cancer incidence and a non-significant reduction in adenoma incidence were observed in study participants given selenium in the form of brewer's yeast; skin cancer incidence was reduced in another study of selenium.176, 178 However, randomized trials specifically designed to examine antioxidant supplements have not supported these observational results. A recent randomized, placebo-controlled trial of oral selenium (200 microgram/d) and vitamin E (400 IU/d), given alone or in combination to men, did not find any reduction in risk prespecified cancer endpoints, including colorectal cancer. ${ }^{179} \mathrm{~A}$ randomized, placebo-controlled trial of vitamin $\mathrm{E}(50 \mathrm{mg} / \mathrm{d})$, beta carotene $(20 \mathrm{mg} / \mathrm{day})$, or the combination in male smokers in Finland did not find that these micronutrients reduced colorectal cancer incidence, yet raised concerns about increased risk for lung cancer and ischemic heart disease related to beta carotene intake.180 Randomized, placebo controlledtrials of patients with prior adenoma did not demonstrate reduced risk of recurrent adenoma in patients given beta carotene supplements, 181 a combination of vitamin $\mathrm{C}$, vitamin $\mathrm{E}$, and beta carotene supplements, 182 or a diet high in anti-oxidant rich fruits and vegetables.20 A metaanalysis of randomized trials of antioxidant supplements, including beta-carotene and vitamins $\mathrm{A}, \mathrm{C}$, and E, did not find that these nutrients reduced incidence of gastrointestinal cancers.

${ }^{171}$ In summary, antioxidant vitamin supplements do not appear to prevent colorectal cancer.

\section{Dietary Patterns}

Recognizing the potential for interactive and synergistic effects between various dietary components, researchers have examined the relationship between colorectal cancer and dietary patterns, rather than specific macronutrients or micronutrients. The NHS associated a "Western diet", consisting of large amounts of red meat and highly refined carbohydrates, with increased risk of colorectal cancer, compared to a "prudent diet" that includes only small amounts of red meat and refined carbohydrates. ${ }^{183}$ These results have been largely supported by analyses of dietary patterns in other populations. ${ }^{184-186}$ Mechanistically, the potential anti-cancer benefit of such dietary patterns might be related to hyperinsulinemia (Figure 1) or inflammation (Figure 2). In summary, although the relative importance of and mechanisms associated with specific macronutrient components or micronutrients are uncertain, consideration of the overall dietary pattern might be more important in modifying colorectal cancer risk.

\section{LIFESTYLE}

\section{Alcohol}

The relationship between alcohol and cancer has been controversial, but most evidence indicates that high intake of alcohol increases risk of colorectal cancer. ${ }^{187}$ The association between alcohol intake and colon adenoma and cancer risk has been observed in most, ${ }^{165}$, 166, 188-208 but not all, prospective cohort and case-control studies.209-212 The HPFS indicated that men who drink more than 2 drinks of alcohol per day had a 2-fold higher risk of colon cancer compared to men who drank less than 0.25 drinks per day. 213 In NHS and HPFS, we have also demonstrated an increased risk of colorectal adenoma with heavy alcohol use. 214 A pooled analysis of 8 prospective cohort studies (including the NHS and HPFS), which 
included nearly 500,000 participants, yielded a multivariate risk of colorectal cancer of 1.24 (95\% CI 1.07-1.42) for consumption of $\geq 30 \mathrm{~g} /$ day of alcohol compared to low intake. 215 Similar associations were observed in the EPIC cohort that also included nearly 500,000 participants.216 This association is not confounded by other risk factors for colorectal cancer and is generally observed for both rectal and colon cancers, as well as for specific types of beverage (beer vs. wine). A meta-analysis corroborated these findings. 217 Of note, a recent study did suggest that alcohol was particularly associated with rectal cancers compared with colon cancers as well as with microsatellite instability low (MSI-L) compared with microsatellite instability high (MSI-H) tumors.218 Because most studies have associated colorectal cancer risk with the highest levels of intake, it is not clear whether intake of less than $30 \mathrm{~g} / \mathrm{day}$ (about 2 drinks/day) alcohol affects risk. The mechanisms by which alcohol promote cancer are unknown, but the ability of alcohol to reduce folate levels is of interest (see section on folate) (Figure 3). ${ }^{219}$ In addition, alcohol might antagonize metabolism of methyl groups, contributing to abnormal DNA methylation. ${ }^{220}$ Finally, alcohol could suppress tumor immune surveillance, delay DNA repair, alter composition of bile acids, or induce cytochrome p450 enzymes to activate hepatic carcinogens. ${ }^{221}$ In summary, it appears prudent to recommend minimizing alcohol intake as a means of preventing colorectal cancer, especially among individuals with high levels of intake.

\section{Tobacco}

The classic studies that linked smoking to cancer incidence and mortality did not associate cigarette smoking with an increased risk of colorectal cancer; ${ }^{222-225}$ most likely because of the long time lag between exposure and colorectal tumor formation, which is approximately 30 to 40 years. ${ }^{226,} 227$ Tobacco releases a range of carcinogenic compounds, including polynuclear aromatic hydrocarbons, heterocyclic amines, nitrosamines, and aromatic amines, 228 that can reach the colorectal mucosa through the circulatory system or direct ingestion.

${ }^{229}$ Tobacco use has been consistently associated with an increased risk of colorectal adenoma; the time required for this association is shorter than for colorectal cancer. ${ }^{230}$

Many of the findings on tobacco and colorectal neoplasia risk were summarized in 1 recent meta-analysis of adenoma studies, 231 and 3 meta-analyses of cancer studies, which generally reached similar conclusions. $232^{-234}$ One of the meta-analyses examined 4 dose-response variables, each of which yielded statistically significant results: daily cigarette consumption (38\% risk increase for an increment of 40 cigarettes/day), duration (20\% risk increase for an increment of 40 years of duration), pack-years (51\% risk increase for an increment of 60 packyears), and age of initiation ( $4 \%$ decrease in risk for a delay of 10 years in smoking initiation). ${ }^{233}$ Interestingly, the incidence of colorectal cancer also appeared to be stronger in past smokers than in current smokers, consistent with the initiation of an irreversible early event, such as genetic damage. However, a more recent prospective study suggests that past smokers who quit for at least 31 years no longer had an increased risk.235 The association appeared to be stronger for rectal cancer than for colon cancer, and possibly for the proximal colon compared to the distal colon,232, 236 as well as for MSI-H compared with MSI-L tumors. ${ }^{218}$ Studies of population-attributable risks in the U.S. have estimated that approximately $15 \%-20 \%$ of colorectal cancers can be attributed to smoking; the proportion might be higher for rectal than for colon cancers. ${ }^{227}, 237-239$ In summary, because cessation of smoking late in life does not necessarily eliminate the increased risk for colorectal cancer, it is critical to prevent smoking in adolescents and young adults and to convince smokers to quit as early in life as possible. Although not presently recommended, more intensive screening of smokers for colorectal neoplasia may be justified given the approximately 2 -fold increase in risk of being diagnosed with an adenoma and a higher risk of colorectal cancer mortality associated with current smoking. ${ }^{240}$ 


\section{Body Mass and Fat Distribution}

Case-control and prospective studies have consistently associated excess body weight (or body mass index [BMI]; $\mathrm{kg} / \mathrm{m} 2$ ) with an increased risk of colon cancer. ${ }^{12}, 168,241^{-} 244$ The HPFS showed that BMI is directly associated with risk, with men in the highest quintile of BMI having nearly a 2 -fold higher risk of colon cancer compared with men in the lowest quintile. ${ }^{242}$ In NHS, women with a BMI $>29 \mathrm{~kg} / \mathrm{m}^{2}$ had a 1.5 -fold increased risk of colon cancer ${ }^{243}$ and 2-fold increased risk of large $(\geq 1 \mathrm{~cm})$ adenoma. ${ }^{245} \mathrm{We}$ recently completed a meta-analysis of 56 case-control and cohort studies, conducted among 7,213,335 individuals including 93 812 cases of colorectal cancer. 246 In that analysis, compared with those with a BMI $<23.0$ $\mathrm{kg} / \mathrm{m}^{2}$, the increased risk of colorectal cancer were $14 \%$ for individuals with a BMI of 23.0$24.9 ; 19 \%$ for a BMI of $25.0-27.4 ; 24 \%$ for BMI of $27.5-29.9$; and $41 \%$ for BMI of $\geq 30.0 \mathrm{~kg} /$ $\mathrm{m}^{2}$. The association was stronger for men than for women, and for the colon than for the rectum. For rectal cancer, a weak association was observed only for men but not for women. In a separate meta-analysis of prospective studies, colon cancer risk increased with increasing waist circumference (33\% increased risk in men and $16 \%$ increase in women per 10-cm increment in waist circumference). Increasing waist-hip-ratio (WHR) was also associated with an increased risk in both men and women. ${ }^{247}$ Controls for various other lifestyle factors did not appreciably alter the findings for BMI or body circumference measures.

The mechanisms whereby obesity increases risk for colon cancer are not well established. However, the mitogenic properties of insulin, obesity-related insulin resistance, and associated hyperinsulinemia might be involved in colon cancer pathogenesis (Figure 1).248 Insulin could also promote colorectal carcinogenesis by increasing levels of bioactive insulin-like growth factor (IGF)-1, either directly or through decreasing levels of IGF binding proteins levels, which leads to increased free IGF-1. In the Physicians' Health Study (PHS) of male physicians, 249 there was 2.5 -fold increased risk of colorectal cancer with increasing levels of plasma Cpeptide (a marker of insulin secretion) when extreme quintiles (highest vs. lowest) were compared. With a few notable exceptions, 250 most other studies have supported this association. $251^{-} 255$ The largest prospective study, which included 1078 cases of colorectal cancer, found that increased levels of C-peptide were associated with a 37\% increase in colorectal cancer risk among men and women.251 Levels of adiponectin, an insulin-sensitizing adipokine, have been inversely associated with the risk of colorectal cancer; men in the HPFS in the highest quintile of adiponectin had a relative risk (RR) of 0.40 (95\% CI, $0.22-0.74$ ) for colorectal cancer compared with men in the lowest quintile. ${ }^{256}$ Another study has also associated adiponectin with adenoma.257

Individuals with diabetes mellitus have also been shown to have an increased risk of colorectal cancer. $258^{-262}$ This may be related not only the previously reviewed metabolic consequences of obesity, physical inactivity, and insulin resistance, but also hyperglycemia associated with the disease. However, the evidence supporting a link between hyperglycemia and colorectal cancer data is inconsistent. Glycosylated hemoglobin (HbA1c), a widely used measure of blood glucose control in patients with diabetes, has been shown to be a more stable indictor of glycemia over a prior 6 to 8 week period than direct measures of plasma glucose. In a large, prospective case-control study nested in the EPIC cohort, increasing HbAlc was associated with a modestly increased risk of colorectal cancer in women, but not men. ${ }^{263}$ HbAic was also associated with risk of colorectal cancer in three other small studies.47, 254, 264 However, several other studies have suggested no association of HbA1c with risk of colorectal cancer or adenoma. ${ }^{265-267}$

Based on these findings, obesity, particularly central adiposity, appears to affect risk of colorectal cancer. As shown in Figure 1, factors that increase insulin resistance, such as abdominal obesity and a sedentary lifestyle, combined with dietary factors (see section on red meat and carbohydrates) that stimulate insulin secretion, might induce hyperinsulinemia, 
which increases risk for colorectal cancer., Obesitymay also be a pro-inflammatory state, whichhas also beenlinked to cancer. (Figure 2). 268-271 For example, a recent study demonstrated an increase in expression of the pro-inflammatory enzyme cyclooxygenase- 2 (COX-2) in normal mucosa adjacent to colorectal tumors patients that were overweight, compared to patients with a healthy body mass index (BMI) ${ }^{272}$ In addition, in a placebocontrolled trial, patients with higher BMIs that were given an aspirin daily $(325-\mathrm{mg}) \mathrm{had}$ a greater reduction in risk of recurrent adenoma $(R R=0.44)$ than those with normal weight $(\mathrm{RR}=1.23$ ) (see section on aspirin and NSAIDs). 273

\section{Physical Activity}

An association between greater levels of physical activity and decreased risk of colon cancer has been one of the most consistently observed.274, 275 The inverse association for colon cancer has been observed both in prospective cohort and case-control studies. In the HPFS, we showed that physical activity was inversely associated with risk for colon cancer, with a RR of 0.53 (95\% CI, 0.32-0.88) for men in the highest quintile of activity, compared to men in the lowest quintile. ${ }^{242}$ Similarly, in the NHS, women who expended $>21$ metabolic equivalent task-hours (MET-hours)/week had a RR of colon cancer of 0.54 (CI, 0.33-0.90), compared with women who expended< 2 MET-hours/week.245 Moreover, higher levels of physical activity have been associated with a reduced risk of colon adenoma and particularly large or advanced lesions.242, 245, 276, 277 Although a physically active lifestyle might be associated with other healthful behaviors, a number of characteristics of the findings indicate that higher levels of physical activity level directly prevent lower colon cancer. The association has been consistently reported in many studies of various designs, in diverse populations, for men and women, and after statistical control for a variety of other lifestyle factors. ${ }^{242,278-280} \mathrm{~A}$ compelling finding is that the inverse association has been observed for both leisure-time and occupational activities, for which patterns of potential confounding lifestyle characteristics are likely to differ.

Overall, the results from these studies indicate a dose-response relation, with risk reduction present across a wide range of physical activity frequency and intensity. In a recent metaanalysis of 52 studies, physically active individuals had a 20\%-30\% lower risk of colon cancer compared to less active individuals. ${ }^{281}$ Whereas risk might be further reduced with even higher levels of activity, even moderate levels of physical activity (e.g., brisk walking for 3-4 hours/ week) are associated with substantial benefits. The mechanisms by which physical activity reduces cancer risk is not known, but could involve, in part, reductions in insulin levels (Figure 1), ${ }^{282,} 283$ and systemic inflammation (Figure 2). Physical activity could also increase colonic motility, though colonic motility has not been definitely linked to colon cancer risk. The cancerpreventing effects of physical activity might also be partially mediated by reducing abdominal adiposity. Nonetheless, evidence supports maintaining a high level of physical activity, even in the absence of significant weight loss, to lower risk of colorectal cancer. In summary, routine physical activity in addition to maintenance of a healthy body weight is associated with significantly lower risk of colorectal cancer.

\section{MEDICATIONS}

\section{Aspirin, NSAIDs, and COX-2 Selective Inhibitors}

Beginning in the 1980s and 1990s, several case-control studies, followed by prospective cohort studies, consistently associated aspirin use with a lower risk of colorectal cancer and adenoma. 284-299 Clinical observations and case series studies, later corroborated by the results of randomized control trials, also demonstrated that NSAIDs such as sulindac and the COX-2 selective inhibitor celecoxib reduced the adenomatous polyp burden among patients with familial adenomatous polyposis. ${ }^{300-} 307$ Subsequently, 4 randomized, placebo-controlled 
trials of aspirin provided compelling evidence that aspirin directly inhibits sporadic carcinogenesis; each trial demonstrated that short-term aspirin use reduces the risk of adenoma recurrence in patients with a prior history of colorectal neoplasia. $151,308^{-310} \mathrm{~A}$ recent metaanalysis of these trials found that aspirin users had pooled risk ratio of $0.83(95 \% \mathrm{CI}, 0.72-$ 0.96 ) for any adenoma and 0.72 (95\% CI, 0.57-0.90) for advanced adenomas. ${ }^{311}$ Although 2 large trials, the PHS and the Women's Health Study, failed to confirm that aspirin protects against colorectal cancer,312, 313 these findings could reflect the low doses of aspirin used or insufficient duration of treatment or follow-up. In support of this explanation, the NHS and HPFS, 314,315 as well as a secondary analysis of data from 2 other randomized trials, found that long-term use of higher doses of aspirin protect against colorectal cancer. ${ }^{316} \mathrm{~A}$ dosedependent relationship is also apparent based on findings from a separate analyses of NHS participants which showed that higher doses of aspirin, especially among women with UGTIA6 polymorphisms that impair aspirin metabolism, were inversely associated with adenoma formation. ${ }^{317,} 318$ This finding was also observed in other cohorts. ${ }^{319}$

Three recent randomized trials showed that the COX-2 selective inhibitors celecoxib and rofecoxib prevented adenoma recurrence among patients with a prior history of adenoma. 320-322 In the Adenoma Prevention with Celecoxib (APC) trial, adenoma recurrence was reduced by $33 \%-45 \%$ in patients that received 3 years of treatment with celecoxib. 322 Unfortunately, the APC trial identified a dose-dependent, 3-fold higher risk of cardiovascular events, which was also observed in a study of rofecoxib.323-326 This subsequently led to the withdrawal of rofecoxib from the market. However, a recent pooled analysis of 6 randomized control trials of celecoxib in patients with non-arthritis indications found that celecoxib (400 $\mathrm{mg}$ twice each day) was not associated with increased cardiovascular risk among patients with low baseline risk of cardiovascular disease.327 Moreover, in the APC trial, a planned 5-year efficacy analysis found that a previous history of atherosclerotic heart disease was the only risk factor that significantly interacted with celecoxib use in the association with cardiovascular events.328 Taken together, this data indicate that celecoxib is relatively safe for individuals that are at low risk for cardiovascular disorders. Unfortunately, many risk factors for colorectal cancer (e.g. body mass index, physical inactivity) overlap with those of cardiovascular disease. 329

Although there have been many observational studies supporting a role for non-aspirin, nonCOX-2 selective, NSAIDs in colorectal cancer prevention, ${ }^{271}, 284-287,289-291,296-299,330^{-}$ 346 randomized trial data are limited. The NSAID sulindac has been shown to reduce polyp burden in patients with FAP.301, ${ }^{303}$ For sporadic adenoma, data are limited to a trial of patients with a history of adenoma that examined the effects of a combination of sulindac and the ornithine decarboxylase inhibitor difluoromethylornitine (DFMO), compared with those of placebo. This combination was selected because of the ability of these reagents to synergistically reduce levels of colonic polyamines (e.g., putrescine, spermidine, and spermine), which are believed to be pro-carcinogenic. DFMO inhibits polyamine synthesis, 347 whereas sulindac is believed to increase polyamine acetylation and export. In this small trial, the combination of DFMO and sulindac reduced the risk of recurrent adenoma by $70 \%$. Although there were concerns about potential adverse effects of DFMO on hearing, there was no significant difference reported in hearing changes or audiogram results from patients given DFMO compared to those given placebo. 348 However, as observed in patients given COX-2selective NSAIDs, there appeared to be a higher incidence of cardiovascular toxicity among patients with a high baseline risk of cardiovascular events that were given sulindac.349 Because the trial was not designed to examine sulindac and DFMO separately, it is uncertain if either agent used alone is an effective chemopreventive.

There have been many proposed mechanisms by which aspirin, NSAIDs, and COX-2 selective inhibitors reduce risk of colorectal neoplasia (Figure 2). However, perhaps the most compelling 
hypothesis is related to the ability of these agents to inhibit COX-2. A specific role for COX-2 in colorectal neoplasia is supported by several lines of evidence: 1) disruption of $C O X-2$ inhibits development of polyps in mice with a mutation in $A P C ; 3502$ ) host expression of COX-2, but not COX-1, is required for survival of mouse tumor xenografts;351 3) COX-2, but not COX-1, is progressively overexpressed in human colorectal adenomas and cancers;352, 3534 ) $C O X-2$ expression is highly upregulated, even in morphologically normal mucosa of $A P C{ }^{\text {min }}$ mice and humans with colorectal cancer. ${ }^{354}$ We recently showed in a large cohort of men and women that regular aspirin use reduced the risk of colorectal cancers that overexpress COX-2 but not the risk of colorectal cancers with weak or absent expression of COX-2. ${ }^{355}$ These data indicate that aspirin likely affects the formation of adenomas and cancer by inhibiting COX-2. Similarly, a secondary analysis of data from a randomized, placebocontrolled trial of aspirin found that genetic variations in $C O X-2$ can modify the effect of aspirin treatment on risk of recurrent adenoma. ${ }^{356}$ Nonetheless, aspirin and NSAIDs have other potential anti-cancer mechanisms that are unrelated to cyclooxygenase, including inhibition of nuclear factor- $\mathrm{kB},{ }^{357}$ induction of apoptosis by activation of $\mathrm{p} 38$ kinase, ${ }^{358}$ and catabolism of polyamines, as previously discussed. ${ }^{359}$

The preceding body of evidence was considered by the United States Preventive Services Task Force (USPSTF) in reaching a consensus statement regarding aspirin and NSAIDs for the prevention of colorectal cancer. The USPSTF concluded that overall, harms outweighed the benefits of aspirin and NSAID use for the prevention of colorectal cancer in asymptomatic adults who are at average risk for colorectal cancer. ${ }^{360}$ For COX-2-selective agents and NSAIDs, concerns about potential cardiovascular events are particularly limiting, as well as the risk of gastrointestinal ulceration and bleeding.361 Although aspirin appears to have a more favorable cardiovascular profile, $362^{-} 364$ hemorrhagic stroke and gastrointestinal bleeding remain a concern, especially with long-term use. ${ }^{315}$ The USPSTF did advocate further investigation into optimizing the risk-benefit profile of aspirin for the purpose of cancer prevention. ${ }^{365}$ A recent international consensus panel reached a similar conclusion, advocating that additional research be conducted into the use of aspirin in high-risk populations for which benefits might outweigh the harms. ${ }^{366}$

Such a subgroup would likely include individuals with established colorectal cancer that have undergone a resection for curative intent. Although such patients generally enjoy a favorable prognosis compared to patients diagnosed with unresectable disease, they remain at high risk of recurrence and death from the disease. Thus, we recently examined, among 1,279 patients with established Stage I, II, III colorectal cancers enrolled in the NHS and HPFS, whether aspirin use can influence prognosis. We found that use of aspirin after diagnosis of colorectal cancer is associated with improved survival from the disease. Compared with non-users, participants who regularly used aspirin after diagnosis had a $29 \%$ reduction in colorectal-cancer specific mortality and a $21 \%$ reduction of overall mortality. Regular aspirin use after diagnosis was associated with a particularly low risk of colorectal-cancer specific mortality among participants in whom primary tumors overexpressed COX-2. Therefore, aspirin might influence the biology of established colorectal tumors, in addition to preventing their occurrence. Moreover, COX-2 or related markers might be used to determine which patients with newly diagnosed colorectal cancer are most likely to respond to anti-COX-2 directed therapies. ${ }^{367}$ A study performed in women with colorectal cancer also supports an effect of NSAIDs on survival. ${ }^{368}$ Nonetheless, randomized trials are needed to confirm these results before routine clinical recommendations can be implemented.

In summary, aspirin and COX-2 selective inhibitors reduce the risk of colorectal neoplasia. Presently, their routine use is not recommended for prevention of colorectal cancer in the general population due to concern about their associated toxicities. However, there are specific populations in which the potential benefit associated with their use may outweigh the risks. 


\section{Post-Menopausal Hormones}

Differences in sex hormones might account for the fact that the ratio of women to men with colorectal cancer is lower before age 50-54 years (i.e. for premenopausal women) than after (i.e. for postmenopausal women). ${ }^{369}, 370$ This observation stimulated research into whether postmenopausal hormones reduce risk of colorectal cancer. Estrogens have been proposed to alter bile acid composition, modulate colonic transit, 371 and decrease production of mitogenic insulin-like growth factor-1.372 Colorectal epithelium expresses estrogen receptors, which might be modulated by age-related promoter hypermethylation. ${ }^{373}$ Colon cancers also express estrogen receptor- $\beta$, which might modulate the effect of exogenous estrogens on tumor growth. With a few exceptions, ${ }^{374-376}$ most prospective studies show an inverse association between use of postmenopausal hormones and risk of colorectal cancer. ${ }^{239}, 377^{-3} 33$ Similarly, most studies have also shown an inverse association between postmenopausal hormone use and risk of colorectal adenoma. $394^{-398}$ Based on data from the NHS, postmenopausal hormone use was associated with a decreased risk of colorectal cancer (multivariate RR, 0.65 ; 95\% CI, 0.500.83 ) and large colorectal adenoma ( $\geq 1 \mathrm{~cm}$ in diameter) (multivariate RR, $0.74,95 \%$ CI, 0.55 0.99). ${ }^{399}$ These results were confirmed in a 2 separate meta-analyses of epidemiological studies.400, 401

These observational results were subsequently confirmed in the WHI estrogen plus progestin randomized, placebo-controlled trial conducted among nearly 17,000 post-menopausal women. In that trial, after a mean of 5.2 years of follow-up, estrogen and progestin were associated with a $37 \%$ reduction in colorectal cancer risk, comparable with the results from prospective, observational studies. However, these results were tempered by a finding that colorectal cancers in women who were given estrogen plus progestin were diagnosed at a more advanced stage than those of patients that received placebo. ${ }^{402}$ In contrast, the WHI estrogenalone trial did not show any benefit for colorectal cancer. ${ }^{403}$ This is in agreement with most observational studies that have also shown an inverse association between colorectal cancer and the combination of estrogen plus progestin, but not for estrogen-alone. ${ }^{388,404,405}$ Of note, one recent study did observe that long duration estrogen-alone therapy but not estrogen plus progestin is associated with lower risk of colorectal cancer. ${ }^{406}$

In summary, although postmenopausal hormone therapy appears to be associated with a lower risk of colorectal cancer, it remains unclear which preparations of estrogen-alone or estrogen plus progestin are optimal. Moreover, because postmenopausal hormones increase the risk of breast cancer and cardiovascular events, ${ }^{402}$ the associated balance of risks and benefits do not support a recommendation of use of postmenopausal hormones as a means of preventing colorectal cancer. ${ }^{407}$

\section{The Overall Potential of Primary Prevention}

Based on the dietary, lifestyle, and medication risk factors we have outlined, there is substantial potential for primary prevention of colorectal cancer through modification of several environmental influences. For dietary factors, although controversy exists regarding the role of specific nutritional elements, consideration of the dietary pattern as a whole might be useful for formulating recommendations. For example, several studies have shown that high intake of red and processed meats, high-fat dairy products, highly refined grains and starches, and sugars are related to a higher risk of colon cancer. Thus, replacing these factors with poultry, fish and plant sources as the primary source of protein; mono-unsaturated, and poly-unsaturated fats as the primary source of fat; and unrefined grains, legumes and fruits as the primary source of carbohydrates is likely to lower risk of colorectal cancer. This benefit is likely to be sustained irrespective of whether the independent benefit of each component or their precise anti-cancer mechanisms is established. Although the role for many supplements, including vitamin D, folate, and B6, remains largely uncertain, calcium supplementation is likely at least modestly 
beneficial, particularly in those with low intake of dietary calcium. Vitamin D intakes of 1000$2000 \mathrm{IU} /$ day might improve overall health status and possibly lower risk of colorectal cancer.

For lifestyle factors, there is compelling evidence that avoidance of smoking and heavy alcohol use, prevention of weight gain, and the maintenance of a reasonable level of physical activity can each have a positive influence on risk of colorectal cancer. In addition, there is strong evidence that medications such as aspirin and NSAIDs are effective chemopreventive drugs. Certain preparations of postmenopausal hormones might also be associated with lower risk of colorectal cancer. Although none of these agents are recommended for widespread primary prevention due to their side effect profile, they provide proof-of-principle of the potential to translate epidemiological findings into clinically efficacious chemopreventive drug interventions.

Taken together, modification of multiple diet and lifestyle factors is likely to have a substantial overall impact on risk of colorectal cancer. In a previous study of the HPFS, as many as $70 \%$ of the overall burden of colon cancers in the U.S. population could be prevented through moderate changes in diet and lifestyle. ${ }^{408}$ Using population-based projections, a separate study reached similar conclusions, albeit with more modest estimates of benefit. ${ }^{409}$ To further integrate the combined effect of modifiable risk factors, we recently developed a comprehensive model of colon cancer incidence that accounted for changes in the influence of risk factors throughout the lifespan. We found that women with profiles of modifiable lifestyle factors that were "high risk" had a nearly 4-fold higher risk of colon cancer compared with women with "low-risk" profiles (Figure 4) ${ }^{410}$ Although endoscopic screening could reduce cancer incidence among these high-risk women, their risk remained significantly higher than women whose lifestyle behaviors placed them in the moderate- or low-risk categories (Figure 5). Thus, primary prevention of colorectal cancer through lifestyle changes is an important complement to colorectal cancer screening in reducing colon cancer incidence. Moreover, because many diet and lifestyle risk factors for colorectal cancer overlap with other chronic illnesses, including cardiovascular disease, further research into these risk factors would have benefits beyond prevention of colorectal cancer.

\section{Acknowledgments}

Funding: Supported by funds from the National Cancer Institute: CA107412 and CA137178 (to ATC); CA 055075, CA087969, CA133891 (to ELG). Dr. Chan is a Damon Runyon Cancer Foundation Clinical Investigator.

\section{REFERENCES}

1. American Cancer Society. Cancer Facts and Figures 2009. Atlanta: American Cancer Society; 2009.

2. Curado, MP.; Edwards, B.; Shin, HR.; Storm, H.; Ferlay, J.; Heanue, M.; Boyle, P. IARC Scientific Publications No. 160. Vol. Vol. IX. Lyon: IARC; 2007. Cancer incidence in five continents.

3. Parkin DM, Bray F, Ferlay J, Pisani P. Global cancer statistics, 2002. CA Cancer J Clin 2005;55:74108. [PubMed: 15761078]

4. Giovannucci E, Willett WC. Dietary factors and risk of colon cancer. Ann Med 1994;26:443-452. [PubMed: 7695871]

5. Burkitt DP. Related disease--related cause? Lancet 1969;2:1229-1231. [PubMed: 4187817]

6. Kritchevsky D. Epidemiology of fibre, resistant starch and colorectal cancer. Eur J Cancer Prev 1995;4:345-352. [PubMed: 7496322]

7. Levi F, Pasche C, Lucchini F, La Vecchia C. Dietary fibre and the risk of colorectal cancer. Eur J Cancer 2001;37:2091-2096. [PubMed: 11597389]

8. Trock B, Lanza E, Greenwald P. Dietary fiber, vegetables, and colon cancer: critical review and metaanalyses of the epidemiologic evidence. J Natl Cancer Inst 1990;82:650-661. [PubMed: 2157027] 
9. Howe GR, Benito E, Castelleto R, Cornee J, Esteve J, Gallagher RP, Iscovich JM, Deng-ao J, Kaaks $\mathrm{R}$, Kune GA, et al. Dietary intake of fiber and decreased risk of cancers of the colon and rectum: evidence from the combined analysis of 13 case-control studies. J Natl Cancer Inst 1992;84:18871896. [PubMed: 1334153]

10. Willett WC, Stampfer MJ, Colditz GA, Rosner BA, Speizer FE. Relation of meat, fat, and fiber intake to the risk of colon cancer in a prospective study among women. N Engl J Med 1990;323:1664-1672. [PubMed: 2172820]

11. Goldbohm RA, van den Brandt PA, van 't Veer P, Brants HA, Dorant E, Sturmans F, Hermus RJ. A prospective cohort study on the relation between meat consumption and the risk of colon cancer. Cancer Res 1994;54:718-723. [PubMed: 8306333]

12. Bostick RM, Potter JD, Kushi LH, Sellers TA, Steinmetz KA, McKenzie DR, Gapstur SM, Folsom AR. Sugar, meat, and fat intake, and non-dietary risk factors for colon cancer incidence in Iowa women (United States). Cancer Causes Control 1994;5:38-52. [PubMed: 8123778]

13. Fuchs CS, Giovannucci EL, Colditz GA, Hunter DJ, Stampfer MJ, Rosner B, Speizer FE, Willett WC. Dietary fiber and the risk of colorectal cancer and adenoma in women. N Engl J Med 1999;340:169-176. [PubMed: 9895396]

14. Michels KB, Giovannucci E, Joshipura KJ, Rosner BA, Stampfer MJ, Fuchs CS, Colditz GA, Speizer FE, Willett WC. Prospective study of fruit and vegetable consumption and incidence of colon and rectal cancers. J Natl Cancer Inst 2000;92:1740-1752. [PubMed: 11058617]

15. Pietinen P, Malila N, Virtanen M, Hartman TJ, Tangrea JA, Albanes D, Virtamo J. Diet and risk of colorectal cancer in a cohort of Finnish men. Cancer Causes Control 1999;10:387-396. [PubMed: 10530608]

16. Park Y, Hunter DJ, Spiegelman D, Bergkvist L, Berrino F, van den Brandt PA, Buring JE, Colditz GA, Freudenheim JL, Fuchs CS, Giovannucci E, Goldbohm RA, Graham S, Harnack L, Hartman AM, Jacobs DR Jr, Kato I, Krogh V, Leitzmann MF, McCullough ML, Miller AB, Pietinen P, Rohan TE, Schatzkin A, Willett WC, Wolk A, Zeleniuch-Jacquotte A, Zhang SM, Smith-Warner SA. Dietary fiber intake and risk of colorectal cancer: a pooled analysis of prospective cohort studies. Jama 2005;294:2849-2857. [PubMed: 16352792]

17. Koushik A, Hunter DJ, Spiegelman D, Beeson WL, van den Brandt PA, Buring JE, Calle EE, Cho E, Fraser GE, Freudenheim JL, Fuchs CS, Giovannucci EL, Goldbohm RA, Harnack L, Jacobs DR Jr, Kato I, Krogh V, Larsson SC, Leitzmann MF, Marshall JR, McCullough ML, Miller AB, Pietinen P, Rohan TE, Schatzkin A, Sieri S, Virtanen MJ, Wolk A, Zeleniuch-Jacquotte A, Zhang SM, SmithWarner SA. Fruits, vegetables, and colon cancer risk in a pooled analysis of 14 cohort studies. J Natl Cancer Inst 2007;99:1471-1483. [PubMed: 17895473]

18. Bingham SA, Day NE, Luben R, Ferrari P, Slimani N, Norat T, Clavel-Chapelon F, Kesse E, Nieters A, Boeing H, Tjonneland A, Overvad K, Martinez C, Dorronsoro M, Gonzalez CA, Key TJ, Trichopoulou A, Naska A, Vineis P, Tumino R, Krogh V, Bueno-de-Mesquita HB, Peeters PH, Berglund G, Hallmans G, Lund E, Skeie G, Kaaks R, Riboli E. Dietary fibre in food and protection against colorectal cancer in the European Prospective Investigation into Cancer and Nutrition (EPIC): an observational study. Lancet 2003;361:1496-1501. [PubMed: 12737858]

19. van Duijnhoven FJ, Bueno-De-Mesquita HB, Ferrari P, Jenab M, Boshuizen HC, Ros MM, Casagrande C, Tjonneland A, Olsen A, Overvad K, Thorlacius-Ussing O, Clavel-Chapelon F, Boutron-Ruault MC, Morois S, Kaaks R, Linseisen J, Boeing H, Nothlings U, Trichopoulou A, Trichopoulos D, Misirli G, Palli D, Sieri S, Panico S, Tumino R, Vineis P, Peeters PH, van Gils CH, Ocke MC, Lund E, Engeset D, Skeie G, Suarez LR, Gonzalez CA, Sanchez MJ, Dorronsoro M, Navarro C, Barricarte A, Berglund G, Manjer J, Hallmans G, Palmqvist R, Bingham SA, Khaw KT, Key TJ, Allen NE, Boffetta P, Slimani N, Rinaldi S, Gallo V, Norat T, Riboli E. Fruit, vegetables, and colorectal cancer risk: the European Prospective Investigation into Cancer and Nutrition. Am J Clin Nutr 2009;89:1441-1452. [PubMed: 19339391]

20. Schatzkin A, Lanza E, Corle D, Lance P, Iber F, Caan B, Shike M, Weissfeld J, Burt R, Cooper MR, Kikendall JW, Cahill J. Lack of effect of a low-fat, high-fiber diet on the recurrence of colorectal adenomas. Polyp Prevention Trial Study Group. N Engl J Med 2000;342:1149-1155. [PubMed: 10770979]

21. Alberts DS, Martinez ME, Roe DJ, Guillen-Rodriguez JM, Marshall JR, van Leeuwen JB, Reid ME, Ritenbaugh C, Vargas PA, Bhattacharyya AB, Earnest DL, Sampliner RE. Lack of effect of a high- 
fiber cereal supplement on the recurrence of colorectal adenomas. Phoenix Colon Cancer Prevention Physicians' Network. N Engl J Med 2000;342:1156-1162. [PubMed: 10770980]

22. Bonithon-Kopp C, Kronborg O, Giacosa A, Rath U, Faivre J. Calcium and fibre supplementation in prevention of colorectal adenoma recurrence: a randomised intervention trial. European Cancer Prevention Organisation Study Group. Lancet 2000;356:1300-1306. [PubMed: 11073017]

23. Le Leu RK, Brown IL, Hu Y, Esterman A, Young GP. Suppression of azoxymethane-induced colon cancer development in rats by dietary resistant starch. Cancer Biol Ther 2007;6:1621-1626. [PubMed: 17932462]

24. Le Leu RK, Brown IL, Hu Y, Morita T, Esterman A, Young GP. Effect of dietary resistant starch and protein on colonic fermentation and intestinal tumourigenesis in rats. Carcinogenesis 2007;28:240245. [PubMed: 17166881]

25. Dronamraju SS, Coxhead JM, Kelly SB, Burn J, Mathers JC. Cell kinetics and gene expression changes in colorectal cancer patients given resistant starch: a randomised controlled trial. Gut 2009;58:413-420. [PubMed: 18978177]

26. Young GP, Le Leu RK. Resistant starch and colorectal neoplasia. J AOAC Int 2004;87:775-786. [PubMed: 15287679]

27. Burn J, Bishop DT, Mecklin JP, Macrae F, Moslein G, Olschwang S, Bisgaard ML, Ramesar R, Eccles D, Maher ER, Bertario L, Jarvinen HJ, Lindblom A, Evans DG, Lubinski J, Morrison PJ, Ho JW, Vasen HF, Side L, Thomas HJ, Scott RJ, Dunlop M, Barker G, Elliott F, Jass JR, Fodde R, Lynch HT, Mathers JC. Effect of aspirin or resistant starch on colorectal neoplasia in the Lynch syndrome. N Engl J Med 2008;359:2567-2578. [PubMed: 19073976]

28. Benito E, Cabeza E, Moreno V, Obrador A, Bosch FX. Diet and colorectal adenomas: a case-control study in Majorca. Int J Cancer 1993;55:213-219. [PubMed: 8370618]

29. Benito E, Obrador A, Stiggelbout A, Bosch FX, Mulet M, Muñoz N, Kaldor J. A population-based case-control study of colorectal cancer in Majorca. I. Dietary factors. Int J Cancer 1990;45:69-76. [PubMed: 2298506]

30. Chao A, Thun MJ, Connell CJ, McCullough ML, Jacobs EJ, Flanders WD, Rodriguez C, Sinha R, Calle EE. Meat consumption and risk of colorectal cancer. Jama 2005;293:172-182. [PubMed: 15644544]

31. Cross AJ, Leitzmann MF, Gail MH, Hollenbeck AR, Schatzkin A, Sinha R. A prospective study of red and processed meat intake in relation to cancer risk. PLoS Med 2007;4:e325. [PubMed: 18076279]

32. English DR, MacInnis RJ, Hodge AM, Hopper JL, Haydon AM, Giles GG. Red meat, chicken, and fish consumption and risk of colorectal cancer. Cancer Epidemiol Biomarkers Prev 2004;13:1509_ 1514. [PubMed: 15342453]

33. Gaard M, Tretli S, Loken EB. Dietary factors and risk of colon cancer: a prospective study of 50,535 young Norwegian men and women. Eur J Cancer Prev 1996;5:445-454. [PubMed: 9061275]

34. Gerhardsson de Verdier M, Hagman U, Peters RK, Steineck G, Overvik E. Meat, cooking methods and colorectal cancer: a case-referent study in Stockholm. Int J Cancer 1991;49:520-525. [PubMed: 1917152]

35. Giovannucci E, Stampfer MJ, Colditz G, Rimm EB, Willett WC. Relationship of diet to risk of colorectal adenoma in men. J Natl Cancer Inst 1992;84:91-98. [PubMed: 1310511]

36. Larsson SC, Rafter J, Holmberg L, Bergkvist L, Wolk A. Red meat consumption and risk of cancers of the proximal colon, distal colon and rectum: the Swedish Mammography Cohort. Int J Cancer 2005;113:829-834. [PubMed: 15499619]

37. Lee HP, Gourley L, Duffy SW, Esteve J, Lee J, Day NE. Colorectal cancer and diet in an Asian population--a case-control study among Singapore Chinese. Int J Cancer 1989;43:1007-1016. [PubMed: 2731998]

38. Martinez ME, Jacobs ET, Ashbeck EL, Sinha R, Lance P, Alberts DS, Thompson PA. Meat intake, preparation methods, mutagens and colorectal adenoma recurrence. Carcinogenesis 2007;28:20192027. [PubMed: 17690112]

39. Neugut AI, Garbowski GC, Lee WC, Murray T, Nieves JW, Forde KA, Treat MR, Waye JD, FenoglioPreiser C. Dietary risk factors for the incidence and recurrence of colorectal adenomatous polyps. A case-control study. Ann Intern Med 1993;118:91-95. [PubMed: 8416323] 
40. Norat T, Bingham S, Ferrari P, Slimani N, Jenab M, Mazuir M, Overvad K, Olsen A, Tjonneland A, Clavel F, Boutron-Ruault MC, Kesse E, Boeing H, Bergmann MM, Nieters A, Linseisen J, Trichopoulou A, Trichopoulos D, Tountas Y, Berrino F, Palli D, Panico S, Tumino R, Vineis P, Bueno-de-Mesquita HB, Peeters PH, Engeset D, Lund E, Skeie G, Ardanaz E, Gonzalez C, Navarro C, Quiros JR, Sanchez MJ, Berglund G, Mattisson I, Hallmans G, Palmqvist R, Day NE, Khaw KT, Key TJ, San Joaquin M, Hemon B, Saracci R, Kaaks R, Riboli E. Meat, fish, and colorectal cancer risk: the European Prospective Investigation into cancer and nutrition. J Natl Cancer Inst 2005;97:906-916. [PubMed: 15956652]

41. Shin A, Shrubsole MJ, Ness RM, Wu H, Sinha R, Smalley WE, Shyr Y, Zheng W. Meat and meatmutagen intake, doneness preference and the risk of colorectal polyps: the Tennessee Colorectal Polyp Study. Int J Cancer 2007;121:136-142. [PubMed: 17354224]

42. Steinmetz KA, Potter JD. Food-group consumption and colon cancer in the Adelaide Case-Control Study. II. Meat, poultry, seafood, dairy foods and eggs. Int J Cancer 1993;53:720-727. [PubMed: 8449595]

43. Stemmermann GN, Nomura AM, Heilbrun LK. Dietary fat and the risk of colorectal cancer. Cancer Res 1984;44:4633-4637. [PubMed: 6467218]

44. Young TB, Wolf DA. Case-control study of proximal and distal colon cancer and diet in Wisconsin. Int J Cancer 1988;42:167-175. [PubMed: 3403062]

45. Norat T, Lukanova A, Ferrari P, Riboli E. Meat consumption and colorectal cancer risk: dose-response meta-analysis of epidemiological studies. Int J Cancer 2002;98:241-256. [PubMed: 11857415]

46. Robertson DJ, Sandler RS, Haile R, Tosteson TD, Greenberg ER, Grau M, Baron JA. Fat, fiber, meat and the risk of colorectal adenomas. Am J Gastroenterol 2005;100:2789-2795. [PubMed: 16393237]

47. Sandhu MS, White IR, McPherson K. Systematic review of the prospective cohort studies on meat consumption and colorectal cancer risk: a meta-analytical approach. Cancer Epidemiol Biomarkers Prev 2001;10:439-446. [PubMed: 11352852]

48. Bird CL, Witte JS, Swendseid ME, Shikany JM, Hunt IF, Frankl HD, Lee ER, Longnecker MP, Haile RW. Plasma ferritin, iron intake, and the risk of colorectal polyps. Am J Epidemiol 1996;144:3441. [PubMed: 8659483]

49. Nelson RL, Davis FG, Sutter E, Sobin LH, Kikendall JW, Bowen P. Body iron stores and risk of colonic neoplasia. J Natl Cancer Inst 1994;86:455-460. [PubMed: 8120921]

50. Shaheen NJ, Silverman LM, Keku T, Lawrence LB, Rohlfs EM, Martin CF, Galanko J, Sandler RS. Association between hemochromatosis (HFE) gene mutation carrier status and the risk of colon cancer. J Natl Cancer Inst 2003;95:154-159. [PubMed: 12529348]

51. Wurzelmann JI, Silver A, Schreinemachers DM, Sandler RS, Everson RB. Iron intake and the risk of colorectal cancer. Cancer Epidemiol Biomarkers Prev 1996;5:503-507. [PubMed: 8827353]

52. Lee DH, Anderson KE, Harnack LJ, Folsom AR, Jacobs DR Jr. Heme iron, zinc, alcohol consumption, and colon cancer: Iowa Women's Health Study. J Natl Cancer Inst 2004;96:403-407. [PubMed: 14996862]

53. Tseng M, Greenberg ER, Sandler RS, Baron JA, Haile RW, Blumberg BS, McGlynn KA. Serum ferritin concentration and recurrence of colorectal adenoma. Cancer Epidemiol Biomarkers Prev 2000;9:625-630. [PubMed: 10868699]

54. Tseng M, Sandler RS, Greenberg ER, Mandel JS, Haile RW, Baron JA. Dietary iron and recurrence of colorectal adenomas. Cancer Epidemiol Biomarkers Prev 1997;6:1029-1032. [PubMed: 9419398]

55. Chan AT, Ma J, Tranah GJ, Giovannucci EL, Rifai N, Hunter DJ, Fuchs CS. Hemochromatosis gene mutations, body iron stores, dietary iron, and risk of colorectal adenoma in women. J Natl Cancer Inst 2005;97:917-926. [PubMed: 15956653]

56. Probst-Hensch NM, Sinha R, Longnecker MP, Witte JS, Ingles SA, Frankl HD, Lee ER, Haile RW. Meat preparation and colorectal adenomas in a large sigmoidoscopy-based case-control study in California (United States). Cancer Causes Control 1997;8:175-183. [PubMed: 9134241]

57. Sinha R, Chow WH, Kulldorff M, Denobile J, Butler J, Garcia-Closas M, Weil R, Hoover RN, Rothman N. Well-done, grilled red meat increases the risk of colorectal adenomas. Cancer Res 1999;59:4320-4324. [PubMed: 10485479]

58. Sugimura T. Carcinogenicity of mutagenic heterocyclic amines formed during the cooking process. Mutat Res 1985;150:33-41. [PubMed: 3889618] 
59. Sugimura T. Overview of carcinogenic heterocyclic amines. Mutat Res 1997;376:211-219. [PubMed: 9202758]

60. Wakabayashi K, Nagao M, Esumi H, Sugimura T. Food-derived mutagens and carcinogens. Cancer Res 1992;52 2092s-2098s.

61. Ferrucci LM, Sinha R, Graubard BI, Mayne ST, Ma X, Schatzkin A, Schoenfeld PS, Cash BD, Flood A, Cross AJ. Dietary meat intake in relation to colorectal adenoma in asymptomatic women. Am J Gastroenterol 2009;104:1231-1240. [PubMed: 19367270]

62. Gunter MJ, Probst-Hensch NM, Cortessis VK, Kulldorff M, Haile RW, Sinha R. Meat intake, cooking-related mutagens and risk of colorectal adenoma in a sigmoidoscopy-based case-control study. Carcinogenesis 2005;26:637-642. [PubMed: 15579480]

63. Ishibe N, Sinha R, Hein DW, Kulldorff M, Strickland P, Fretland AJ, Chow WH, Kadlubar FF, Lang NP, Rothman N. Genetic polymorphisms in heterocyclic amine metabolism and risk of colorectal adenomas. Pharmacogenetics 2002;12:145-150. [PubMed: 11875368]

64. Kampman E, Slattery ML, Bigler J, Leppert M, Samowitz W, Caan BJ, Potter JD. Meat consumption, genetic susceptibility, and colon cancer risk: a United States multicenter case-control study. Cancer Epidemiol Biomarkers Prev 1999;8:15-24. [PubMed: 9950235]

65. Le Marchand L, Hankin JH, Pierce LM, Sinha R, Nerurkar PV, Franke AA, Wilkens LR, Kolonel LN, Donlon T, Seifried A, Custer LJ, Lum-Jones A, Chang W. Well-done red meat, metabolic phenotypes and colorectal cancer in Hawaii. Mutat Res 2002;506-507:205-214.

66. Nowell S, Coles B, Sinha R, MacLeod S, Luke Ratnasinghe D, Stotts C, Kadlubar FF, Ambrosone $\mathrm{CB}$, Lang NP. Analysis of total meat intake and exposure to individual heterocyclic amines in a casecontrol study of colorectal cancer: contribution of metabolic variation to risk. Mutat Res 2002;506507:175-185.

67. Sinha R, Kulldorff M, Chow WH, Denobile J, Rothman N. Dietary intake of heterocyclic amines, meat-derived mutagenic activity, and risk of colorectal adenomas. Cancer Epidemiol Biomarkers Prev 2001;10:559-562. [PubMed: 11352869]

68. Sinha R, Kulldorff M, Gunter MJ, Strickland P, Rothman N. Dietary benzo[a]pyrene intake and risk of colorectal adenoma. Cancer Epidemiol Biomarkers Prev 2005;14:2030-2034. [PubMed: 16103456]

69. Sinha R, Peters U, Cross AJ, Kulldorff M, Weissfeld JL, Pinsky PF, Rothman N, Hayes RB. Meat, meat cooking methods and preservation, and risk for colorectal adenoma. Cancer Res 2005;65:80348041. [PubMed: 16140978]

70. Wu K, Giovannucci E, Byrne C, Platz EA, Fuchs C, Willett WC, Sinha R. Meat mutagens and risk of distal colon adenoma in a cohort of U.S. men. Cancer Epidemiol Biomarkers Prev 2006;15:11201125. [PubMed: 16775169]

71. Gunter MJ, Divi RL, Kulldorff M, Vermeulen R, Haverkos KJ, Kuo MM, Strickland P, Poirier MC, Rothman N, Sinha R. Leukocyte polycyclic aromatic hydrocarbon-DNA adduct formation and colorectal adenoma. Carcinogenesis 2007;28:1426-1429. [PubMed: 17277232]

72. Peters U, DeMarini DM, Sinha R, Brooks LR, Warren SH, Chatterjee N, Rothman N. Urinary mutagenicity and colorectal adenoma risk. Cancer Epidemiol Biomarkers Prev 2003;12:1253-1256. [PubMed: 14652290]

73. Butler LM, Millikan RC, Sinha R, Keku TO, Winkel S, Harlan B, Eaton A, Gammon MD, Sandler RS. Modification by N-acetyltransferase 1 genotype on the association between dietary heterocyclic amines and colon cancer in a multiethnic study. Mutat Res 2008;638:162-174. [PubMed: 18022202]

74. Chen J, Stampfer MJ, Hough HL, Garcia-Closas M, Willett WC, Hennekens CH, Kelsey KT, Hunter DJ. A prospective study of $\mathrm{N}$-acetyltransferase genotype, red meat intake, and risk of colorectal cancer. Cancer Res 1998;58:3307-3311. [PubMed: 9699660]

75. Joshi AD, Corral R, Siegmund KD, Haile RW, Le Marchand L, Martinez ME, Ahnen DJ, Sandler RS, Lance P, Stern MC. Red meat and poultry intake, polymorphisms in the nucleotide excision repair and mismatch repair pathways and colorectal cancer risk. Carcinogenesis 2009;30:472-479. [PubMed: 19029193]

76. Lang NP, Butler MA, Massengill J, Lawson M, Stotts RC, Hauer-Jensen M, Kadlubar FF. Rapid metabolic phenotypes for acetyltransferase and cytochrome P4501A2 and putative exposure to food- 
borne heterocyclic amines increase the risk for colorectal cancer or polyps. Cancer Epidemiol Biomarkers Prev 1994;3:675-682. [PubMed: 7881341]

77. Le Marchand L, Hankin JH, Wilkens LR, Pierce LM, Franke A, Kolonel LN, Seifried A, Custer LJ, Chang W, Lum-Jones A, Donlon T. Combined effects of well-done red meat, smoking, and rapid Nacetyltransferase 2 and CYP1A2 phenotypes in increasing colorectal cancer risk. Cancer Epidemiol Biomarkers Prev 2001;10:1259-1266. [PubMed: 11751443]

78. Probst-Hensch NM, Haile RW, Ingles SA, Longnecker MP, Han CY, Lin BK, Lee DB, Sakamoto GT, Frankl HD, Lee ER, et al. Acetylation polymorphism and prevalence of colorectal adenomas. Cancer Res 1995;55:2017-2020. [PubMed: 7743494]

79. Roberts-Thomson IC, Ryan P, Khoo KK, Hart WJ, McMichael AJ, Butler RN. Diet, acetylator phenotype, and risk of colorectal neoplasia. Lancet 1996;347:1372-1374. [PubMed: 8637343]

80. Shin A, Shrubsole MJ, Rice JM, Cai Q, Doll MA, Long J, Smalley WE, Shyr Y, Sinha R, Ness RM, Hein DW, Zheng W. Meat intake, heterocyclic amine exposure, and metabolizing enzyme polymorphisms in relation to colorectal polyp risk. Cancer Epidemiol Biomarkers Prev 2008;17:320329. [PubMed: 18268115]

81. Chan AT, Tranah GJ, Giovannucci EL, Willett WC, Hunter DJ, Fuchs CS. Prospective study of Nacetyltransferase-2 genotypes, meat intake, smoking and risk of colorectal cancer. Int J Cancer 2005;115:648-652. [PubMed: 15700302]

82. Chiu BC, Ji BT, Dai Q, Gridley G, McLaughlin JK, Gao YT, Fraumeni JF Jr, Chow WH. Dietary factors and risk of colon cancer in shanghai, china. Cancer Epidemiol Biomarkers Prev 2003;12:201208. [PubMed: 12646508]

83. Kato I, Akhmedkhanov A, Koenig K, Toniolo PG, Shore RE, Riboli E. Prospective study of diet and female colorectal cancer: the New York University Women's Health Study. Nutrition and Cancer 1997;28:276-281. [PubMed: 9343837]

84. Geelen A, Schouten JM, Kamphuis C, Stam BE, Burema J, Renkema JM, Bakker EJ, van't Veer P, Kampman E. Fish consumption, n-3 fatty acids, and colorectal cancer: a meta-analysis of prospective cohort studies. Am J Epidemiol 2007;166:1116-1125. [PubMed: 17823383]

85. Hall MN, Campos H, Li H, Sesso HD, Stampfer MJ, Willett WC, Ma J. Blood levels of long-chain polyunsaturated fatty acids, aspirin, and the risk of colorectal cancer. Cancer Epidemiol Biomarkers Prev 2007;16:314-321. [PubMed: 17301265]

86. Hall MN, Chavarro JE, Lee IM, Willett WC, Ma J. A 22-year prospective study of fish, n-3 fatty acid intake, and colorectal cancer risk in men. Cancer Epidemiol Biomarkers Prev 2008;17:1136-1143. [PubMed: 18483335]

87. Larsson SC, Kumlin M, Ingelman-Sundberg M, Wolk A. Dietary long-chain n-3 fatty acids for the prevention of cancer: a review of potential mechanisms. Am J Clin Nutr 2004;79:935-945. [PubMed: 15159222]

88. Oh K, Willett WC, Fuchs CS, Giovannucci E. Dietary marine n-3 fatty acids in relation to risk of distal colorectal adenoma in women. Cancer Epidemiol Biomarkers Prev 2005;14:835-841. [PubMed: 15824153]

89. Daniel CR, McCullough ML, Patel RC, Jacobs EJ, Flanders WD, Thun MJ, Calle EE. Dietary intake of omega- 6 and omega- 3 fatty acids and risk of colorectal cancer in a prospective cohort of U.S. men and women. Cancer Epidemiol Biomarkers Prev 2009;18:516-525. [PubMed: 19190143]

90. Lopez-Garcia E, Schulze MB, Manson JE, Meigs JB, Albert CM, Rifai N, Willett WC, Hu FB. Consumption of (n-3) fatty acids is related to plasma biomarkers of inflammation and endothelial activation in women. J Nutr 2004;134:1806-1811. [PubMed: 15226473]

91. Lim K, Han C, Xu L, Isse K, Demetris AJ, Wu T. Cyclooxygenase-2-derived prostaglandin E2 activates beta-catenin in human cholangiocarcinoma cells: evidence for inhibition of these signaling pathways by omega 3 polyunsaturated fatty acids. Cancer Res 2008;68:553-560. [PubMed: 18199552]

92. Nowak J, Weylandt KH, Habbel P, Wang J, Dignass A, Glickman JN, Kang JX. Colitis-associated colon tumorigenesis is suppressed in transgenic mice rich in endogenous n-3 fatty acids. Carcinogenesis 2007;28:1991-1995. [PubMed: 17634405] 
93. Benito E, Stiggelbout A, Bosch FX, Obrador A, Kaldor J, Mulet M, Munoz N. Nutritional factors in colorectal cancer risk: a case-control study in Majorca. Int J Cancer 1991;49:161-167. [PubMed: 1652565]

94. Freudenheim JL, Graham S, Marshall JR, Haughey BP, Wilkinson G. A case-control study of diet and rectal cancer in western New York. Am J Epidemiol 1990;131:612-624. [PubMed: 2156419]

95. Franceschi S, Dal Maso L, Augustin L, Negri E, Parpinel M, Boyle P, Jenkins DJ, La Vecchia C. Dietary glycemic load and colorectal cancer risk. Ann Oncol 2001;12:173-178. [PubMed: 11300319]

96. Gnagnarella P, Gandini S, La Vecchia C, Maisonneuve P. Glycemic index, glycemic load, and cancer risk: a meta-analysis. Am J Clin Nutr 2008;87:1793-1801. [PubMed: 18541570]

97. Higginbotham S, Zhang ZF, Lee IM, Cook NR, Giovannucci E, Buring JE, Liu S. Dietary glycemic load and risk of colorectal cancer in the Women's Health Study. J Natl Cancer Inst 2004;96:229-233. [PubMed: 14759990]

98. McCarl M, Harnack L, Limburg PJ, Anderson KE, Folsom AR. Incidence of colorectal cancer in relation to glycemic index and load in a cohort of women. Cancer Epidemiol Biomarkers Prev 2006;15:892-896. [PubMed: 16702366]

99. Michaud DS, Fuchs CS, Liu S, Willett WC, Colditz GA, Giovannucci E. Dietary glycemic load, carbohydrate, sugar, and colorectal cancer risk in men and women. Cancer Epidemiol Biomarkers Prev 2005;14:138-147. [PubMed: 15668487]

100. Flood A, Peters U, Jenkins DJ, Chatterjee N, Subar AF, Church TR, Bresalier R, Weissfeld JL, Hayes RB, Schatzkin A. Carbohydrate, glycemic index, and glycemic load and colorectal adenomas in the Prostate, Lung, Colorectal, and Ovarian Screening Study. Am J Clin Nutr 2006;84:11841192. [PubMed: 17093173]

101. Howarth NC, Murphy SP, Wilkens LR, Henderson BE, Kolonel LN. The association of glycemic load and carbohydrate intake with colorectal cancer risk in the Multiethnic Cohort Study. Am J Clin Nutr 2008;88:1074-1082. [PubMed: 18842796]

102. Kabat GC, Shikany JM, Beresford SA, Caan B, Neuhouser ML, Tinker LF, Rohan TE. Dietary carbohydrate, glycemic index, and glycemic load in relation to colorectal cancer risk in the Women's Health Initiative. Cancer Causes Control 2008;19:1291-1298. [PubMed: 18618276]

103. Larsson SC, Giovannucci E, Wolk A. Dietary carbohydrate, glycemic index, and glycemic load in relation to risk of colorectal cancer in women. Am J Epidemiol 2007;165:256-261. [PubMed: 17118965]

104. Mulholland HG, Murray LJ, Cardwell CR, Cantwell MM. Glycemic index, glycemic load, and risk of digestive tract neoplasms: a systematic review and meta-analysis. Am J Clin Nutr 2009;89:568576. [PubMed: 19088152]

105. Oh K, Willett WC, Fuchs CS, Giovannucci EL. Glycemic index, glycemic load, and carbohydrate intake in relation to risk of distal colorectal adenoma in women. Cancer Epidemiol Biomarkers Prev 2004;13:1192-1198. [PubMed: 15247130]

106. Strayer L, Jacobs DR Jr, Schairer C, Schatzkin A, Flood A. Dietary carbohydrate, glycemic index, and glycemic load and the risk of colorectal cancer in the BCDDP cohort. Cancer Causes Control 2007;18:853-863. [PubMed: 17605083]

107. Weijenberg MP, Mullie PF, Brants HA, Heinen MM, Goldbohm RA, van den Brandt PA. Dietary glycemic load, glycemic index and colorectal cancer risk: results from the Netherlands Cohort Study. Int J Cancer 2008;122:620-629. [PubMed: 17935129]

108. Newmark HL, Wargovich MJ, Bruce WR. Colon cancer and dietary fat, phosphate, and calcium: a hypothesis. Journal of the National Cancer Institute 1984;72:1323-1325. [PubMed: 6587152]

109. van der Meer R, de Vries HT. Differential binding of glycine- and taurine-conjugated bile acids to insoluble calcium phosphate. Biochem J 1985;229:265-268. [PubMed: 4038261]

110. Fedirko V, Bostick RM, Flanders WD, Long Q, Shaukat A, Rutherford RE, Daniel CR, Cohen V, Dash C. Effects of vitamin D and calcium supplementation on markers of apoptosis in normal colon mucosa: a randomized, double-blind, placebo-controlled clinical trial. Cancer Prev Res (Phila Pa) 2009;2:213-223.

111. Fedirko V, Bostick RM, Flanders WD, Long Q, Sidelnikov E, Shaukat A, Daniel CR, Rutherford RE, Woodard JJ. Effects of Vitamin D and Calcium on Proliferation and Differentiation In Normal Colon Mucosa: a Randomized Clinical Trial. Cancer Epidemiol Biomarkers Prev. 2009 
112. Lipkin M, Newmark H. Effect of added dietary calcium on colonic epithelial-cell proliferation in subjects at high risk for familial colonic cancer. New England Journal of Medicine 1985;313:13811384. [PubMed: 4058532]

113. Martinez ME, Willett WC. Calcium, vitamin D, and colorectal cancer: a review of the epidemiologic evidence. Cancer Epidemiol Biomarkers Prev 1998;7:163-168. [PubMed: 9488592]

114. Wu K, Willett WC, Fuchs CS, Colditz GA, Giovannucci EL. Calcium intake and risk of colon cancer in women and men. J Natl Cancer Inst 2002;94:437-446. [PubMed: 11904316]

115. Cho E, Smith-Warner SA, Spiegelman D, Beeson WL, van den Brandt PA, Colditz GA, Folsom AR, Fraser GE, Freudenheim JL, Giovannucci E, Goldbohm RA, Graham S, Miller AB, Pietinen P, Potter JD, Rohan TE, Terry P, Toniolo P, Virtanen MJ, Willett WC, Wolk A, Wu K, Yaun SS, Zeleniuch-Jacquotte A, Hunter DJ. Dairy foods, calcium, and colorectal cancer: a pooled analysis of 10 cohort studies. J Natl Cancer Inst 2004;96:1015-1022. [PubMed: 15240785]

116. Baron JA, Beach M, Mandel JS, van Stolk RU, Haile RW, Sandler RS, Rothstein R, Summers RW, Snover DC, Beck GJ, Bond JH, Greenberg ER. Calcium supplements for the prevention of colorectal adenomas. Calcium Polyp Prevention Study Group. N Engl J Med 1999;340:101-107. [PubMed: 9887161]

117. Wallace K, Baron JA, Cole BF, Sandler RS, Karagas MR, Beach MA, Haile RW, Burke CA, Pearson LH, Mandel JS, Rothstein R, Snover DC. Effect of calcium supplementation on the risk of large bowel polyps. J Natl Cancer Inst 2004;96:921-925. [PubMed: 15199111]

118. Grau MV, Baron JA, Sandler RS, Wallace K, Haile RW, Church TR, Beck GJ, Summers RW, Barry EL, Cole BF, Snover DC, Rothstein R, Mandel JS. Prolonged effect of calcium supplementation on risk of colorectal adenomas in a randomized trial. J Natl Cancer Inst 2007;99:129-136. [PubMed: 17227996]

119. Grau MV, Baron JA, Sandler RS, Haile RW, Beach ML, Church TR, Heber D. Vitamin D, Calcium Supplementation, and Colorectal Adenomas: Results of a Randomized Trial. J Natl Cancer Inst 2003;95:1765-1771. [PubMed: 14652238]

120. Garland CF, Garland FC. Do Sunlight and Vitamin D Reduce the Likelihood of Colon Cancer? Int. J. Epidemiol 1980;9:227-231. \%R 10.1093/ije/9.3.227. [PubMed: 7440046]

121. Giovannucci E. The epidemiology of vitamin D and cancer incidence and mortality: a review (United States). Cancer Causes and Control 2005;16:83-95. [PubMed: 15868450]

122. Froicu M, Weaver V, Wynn TA, McDowell MA, Welsh JE, Cantorna MT. A crucial role for the vitamin D receptor in experimental inflammatory bowel diseases. Mol Endocrinol 2003;17:23862392. [PubMed: 14500760]

123. Froicu M, Zhu Y, Cantorna MT. Vitamin D receptor is required to control gastrointestinal immunity in IL-10 knockout mice. Immunology 2006;117:310-318. [PubMed: 16476050]

124. Cantorna MT, Munsick C, Bemiss C, Mahon BD. 1,25-Dihydroxycholecalciferol prevents and ameliorates symptoms of experimental murine inflammatory bowel disease. J. Nutr 2000;130:2648-2652. [PubMed: 11053501]

125. Fichera A, Little N, Dougherty U, Mustafi R, Cerda S, Li YC, Delgado J, Arora A, Campbell LK, Joseph L, Hart J, Noffsinger A, Bissonnette M. A vitamin D analogue inhibits colonic carcinogenesis in the AOM/DSS model. J Surg Res 2007;142:239-245. [PubMed: 17574271]

126. Zhu Y, Mahon BD, Froicu M, Cantorna MT. Calcium and 1 alpha,25-dihydroxyvitamin D3 target the TNF-alpha pathway to suppress experimental inflammatory bowel disease. Eur J Immunol 2005;35:217-224. [PubMed: 15593122]

127. Dresner-Pollak R, Ackerman Z, Eliakim R, Karban A, Chowers Y, Fidder HH. The BsmI vitamin $D$ receptor gene polymorphism is associated with ulcerative colitis in Jewish Ashkenazi patients. Genet Test 2004;8:417-420. [PubMed: 15684874]

128. Gilman J, Shanahan F, Cashman KD. Altered levels of biochemical indices of bone turnover and bone-related vitamins in patients with Crohn's disease and ulcerative colitis. Aliment Pharmacol Ther 2006;23:1007-1016. [PubMed: 16573803]

129. Lim WC, Hanauer SB, Li YC. Mechanisms of disease: vitamin D and inflammatory bowel disease. Nat Clin Pract Gastroenterol Hepatol 2005;2:308-315. [PubMed: 16265284]

130. Peterlik M, Cross HS. Vitamin D and calcium deficits predispose for multiple chronic diseases. Eur J Clin Invest 2005;35:290-304. [PubMed: 15860041] 
131. Simmons JD, Mullighan C, Welsh KI, Jewell DP. Vitamin D receptor gene polymorphism: association with Crohn's disease susceptibility. Gut 2000;47:211-214. [PubMed: 10896912]

132. Dietrich T, Nunn M, Dawson-Hughes B, Bischoff-Ferrari HA. Association between serum concentrations of 25-hydroxyvitamin D and gingival inflammation. Am J Clin Nutr 2005;82:575580. [PubMed: 16155270]

133. Dietrich T, Joshipura KJ, Dawson-Hughes B, Bischoff-Ferrari HA. Association between serum concentrations of 25-hydroxyvitamin D3 and periodontal disease in the US population. Am J Clin Nutr 2004;80:108-113. [PubMed: 15213036]

134. Timms PM, Mannan N, Hitman GA, Noonan K, Mills PG, Syndercombe-court D, Aganna E, Price CP, Boucher BJ. Circulating MMP9, vitamin D and variation in the TIMP-1 response with VDR genotype: mechanisms for inflammatory damage in chronic disorders? QJM 2002;95:787-796. [PubMed: 12454321]

135. Otani T, Iwasaki M, Sasazuki S, Inoue M, Tsugane S. Plasma vitamin D and risk of colorectal cancer: the Japan Public Health Center-Based Prospective Study. Br J Cancer 2007;97:446-451. [PubMed: 17622244]

136. Braun MM, Helzlsouer KJ, Hollis BW, Comstock GW. Colon cancer and serum vitamin D metabolite levels 10-17 years prior to diagnosis. American Journal of Epidemiology 1995;142:608611. [PubMed: 7653469]

137. Feskanich D, Ma J, Fuchs CS, Kirkner GJ, Hankinson SE, Hollis BW, Giovannucci E. Plasma vitamin D metabolites and risk of colorectal cancer in women. Cancer Epidemiology, Biomarkers and Prevention 2004;13:1502-1508.

138. Garland CF, Comstock GW, Garland FC, Helsing KJ, Shaw EK, Gorham ED. Serum 25hydroxyvitamin D and colon cancer: eight-year prospective study. Lancet 1989;2:1176-1178. [PubMed: 2572900]

139. Levine AJ, Harper JM, Ervin CM, Chen YH, Harmon E, Xue S, Lee ER, Frankel HD, Haile RW. Serum 25-hydroxyvitamin D, dietary calcium in take, and distal colorectal adenoma risk. Nutrition and Cancer 2001;39:35-41. [PubMed: 11588900]

140. Peters U, McGlynn KA, Chatterjee N, Gunter E, Garcia-Closas M, Rothman N, Sinha R. Vitamin $\mathrm{D}$, calcium, and vitamin D receptor polymorphism in colorectal adenomas. Cancer Epidemiology, Biomarkers and Prevention 2001;10:1267-1274.

141. Platz EA, Hankinson SE, Hollis BW, Colditz GA, Hunter DJ, Speizer FE, Giovannucci E. Plasma 1,25-dihydroxy-and 25-hydroxyvitamin D and adenomatous polyps of the distal colorectum. Cancer Epidemiology, Biomarkers and Prevention 2000;9:1059-1065.

142. Tangrea J, Helzlsouer K, Pietinen P, Taylor P, Hollis B, Virtamo J, Albanes D. Serum levels of vitamin D metabolites and the subsequent risk of colon and rectal cancer in Finnish men. Cancer Causes and Control 1997;8:615-625. [PubMed: 9242478]

143. Wactawski-Wende J, Kotchen JM, Anderson GL, Assaf AR, Brunner RL, O'Sullivan MJ, Margolis KL, Ockene JK, Phillips L, Pottern L, Prentice RL, Robbins J, Rohan TE, Sarto GE, Sharma S, Stefanick ML, Van Horn L, Wallace RB, Whitlock E, Bassford T, Beresford SA, Black HR, Bonds DE, Brzyski RG, Caan B, Chlebowski RT, Cochrane B, Garland C, Gass M, Hays J, Heiss G, Hendrix SL, Howard BV, Hsia J, Hubbell FA, Jackson RD, Johnson KC, Judd H, Kooperberg CL, Kuller LH, LaCroix AZ, Lane DS, Langer RD, Lasser NL, Lewis CE, Limacher MC, Manson JE. Calcium plus vitamin D supplementation and the risk of colorectal cancer. New England Journal of Medicine 2006;354:684-696. [PubMed: 16481636]

144. Gorham ED, Garland CF, Garland FC, Grant WB, Mohr SB, Lipkin M, Newmark HL, Giovannucci E, Wei M, Holick MF. Vitamin D and prevention of colorectal cancer. J Steroid Biochem Mol Biol 2005;97:179-194. [PubMed: 16236494]

145. Martinez ME, Giovannucci EL, Colditz GA, Stampfer MJ, Hunter DJ, Speizer FE, Wing A, Willett WC. Calcium, vitamin D, and the occurrence of colorectal cancer among women. J Natl Cancer Inst 1996;88:1375-1382. [PubMed: 8827015]

146. Ding EL, Mehta S, Fawzi WW, Giovannucci EL. Interaction of estrogen therapy with calcium and vitamin D supplementation on colorectal cancer risk: Reanalysis of Women's Health Initiative randomized trial. Int J Cancer. 2007 
147. Giovannucci E. Epidemiologic studies of folate and colorectal neoplasia: a review. Journal of Nutrition 2002;132 2350S-2355S.

148. Sanjoaquin MA, Allen N, Couto E, Roddam AW, Key TJ. Folate intake and colorectal cancer risk: a meta-analytical approach. International Journal of Cancer 2005;113:825-828.

149. Schernhammer ES, Ogino S, Fuchs CS. Folate and vitamin B6 intake and risk of colon cancer in relation to p53 expression. Gastroenterology 2008;135:770-780. [PubMed: 18619459]

150. Taioli E, Garza MA, Ahn YO, Bishop DT, Bost J, Budai B, Chen K, Gemignani F, Keku T, Lima CS, Le Marchand L, Matsuo K, Moreno V, Plaschke J, Pufulete M, Thomas SB, Toffoli G, Wolf CR, Moore CG, Little J. Meta- and pooled analyses of the methylenetetrahydrofolate reductase (MTHFR) C677T polymorphism and colorectal cancer: a HuGE-GSEC review. Am J Epidemiol 2009;170:1207-1221. [PubMed: 19846566]

151. Logan RF, Grainge MJ, Shepherd VC, Armitage NC, Muir KR. Aspirin and folic acid for the prevention of recurrent colorectal adenomas. Gastroenterology 2008;134:29-38. [PubMed: 18022173]

152. Wu K, Platz EA, Willett WC, Fuchs CS, Selhub J, Rosner BA, Hunter DJ, Giovannucci E. A randomized trial on folic acid supplementation and risk of recurrent colorectal adenoma. Am J Clin Nutr 2009;90:1623-1631. [PubMed: 19864409]

153. Cole BF, Baron JA, Sandler RS, Haile RW, Ahnen DJ, Bresalier RS, McKeown-Eyssen G, Summers RW, Rothstein RI, Burke CA, Snover DC, Church TR, Allen JI, Robertson DJ, Beck GJ, Bond JH, Byers T, Mandel JS, Mott LA, Pearson LH, Barry EL, Rees JR, Marcon N, Saibil F, Ueland PM, Greenberg ER. Folic acid for the prevention of colorectal adenomas: a randomized clinical trial. JAMA 2007;297:2351-2359. [PubMed: 17551129]

154. Kim YI. Folate, colorectal carcinogenesis, and DNA methylation: lessons from animal studies. Environ Mol Mutagen 2004;44:10-25. [PubMed: 15199543]

155. Giovannucci E, Ogino S. DNA methylation, field effects, and colorectal cancer. J Natl Cancer Inst 2005;97:1317-1319. [PubMed: 16174847]

156. Ishihara J, Otani T, Inoue M, Iwasaki M, Sasazuki S, Tsugane S. Low intake of vitamin B-6 is associated with increased risk of colorectal cancer in Japanese men. J Nutr 2007;137:1808-1814. [PubMed: 17585035]

157. Larsson SC, Giovannucci E, Wolk A. Vitamin B6 intake, alcohol consumption, and colorectal cancer: a longitudinal population-based cohort of women. Gastroenterology 2005;128:1830-1837. [PubMed: 15940618]

158. Le Marchand L, White KK, Nomura AM, Wilkens LR, Selhub JS, Tiirikainen M, Goodman MT, Murphy SP, Henderson BE, Kolonel LN. Plasma levels of B vitamins and colorectal cancer risk: the multiethnic cohort study. Cancer Epidemiol Biomarkers Prev 2009;18:2195-2201. [PubMed: 19661077]

159. Lee JE, Li H, Giovannucci E, Lee IM, Selhub J, Stampfer M, Ma J. Prospective study of plasma vitamin B6 and risk of colorectal cancer in men. Cancer Epidemiol Biomarkers Prev 2009;18:11971202. [PubMed: 19336555]

160. Theodoratou E, Farrington SM, Tenesa A, McNeill G, Cetnarskyj R, Barnetson RA, Porteous ME, Dunlop MG, Campbell H. Dietary vitamin B6 intake and the risk of colorectal cancer. Cancer Epidemiol Biomarkers Prev 2008;17:171-182. [PubMed: 18199722]

161. Wei EK, Giovannucci E, Selhub J, Fuchs CS, Hankinson SE, Ma J. Plasma vitamin B6 and the risk of colorectal cancer and adenoma in women. J Natl Cancer Inst 2005;97:684-692. [PubMed: 15870439]

162. Zhang SM, Moore SC, Lin J, Cook NR, Manson JE, Lee IM, Buring JE. Folate, vitamin B6, multivitamin supplements, and colorectal cancer risk in women. Am J Epidemiol 2006;163:108115. [PubMed: 16339055]

163. de Vogel S, Dindore V, van Engeland M, Goldbohm RA, van den Brandt PA, Weijenberg MP. Dietary folate, methionine, riboflavin, and vitamin B-6 and risk of sporadic colorectal cancer. $\mathrm{J}$ Nutr 2008;138:2372-2378. [PubMed: 19022960]

164. Heilbrun LK, Nomura A, Hankin JH, Stemmermann GN. Diet and colorectal cancer with special reference to fiber intake. Int J Cancer 1989;44:1-6. [PubMed: 2545631] 
165. Potter JD, McMichael AJ. Diet and cancer of the colon and rectum: a case-control study. J Natl Cancer Inst 1986;76:557-569. [PubMed: 3007842]

166. Stemmermann GN, Nomura AMY, Chyou PH, Yoshizawa C. Prospective study of alcohol intake and large bowel cancer. Digestive Diseases and Sciences 1990;35:1414-1420. [PubMed: 2226103]

167. Tseng M, Murray SC, Kupper LL, Sandler RS. Micronutrients and the risk of colorectal adenomas. Am J Epidemiol 1996;144:1005-1014. [PubMed: 8942430]

168. Wu AH, Paganini-Hill A, Ross RK, Henderson BE. Alcohol, physical activity and other risk factors for colorectal cancer: a prospective study. Br J Cancer 1987;55:687-694. [PubMed: 3620314]

169. van den Brandt PA, Goldbohm RA, van 't Veer P, Bode P, Dorant E, Hermus RJ, Sturmans F. A prospective cohort study on toenail selenium levels and risk of gastrointestinal cancer. J Natl Cancer Inst 1993;85:224-229. [PubMed: 8423627]

170. Wallace K, Byers T, Morris JS, Cole BF, Greenberg ER, Baron JA, Gudino A, Spate V, Karagas MR. Prediagnostic serum selenium concentration and the risk of recurrent colorectal adenoma: a nested case-control study. Cancer Epidemiol Biomarkers Prev 2003;12:464-467. [PubMed: 12750244]

171. Bjelakovic G, Nikolova D, Simonetti RG, Gluud C. Antioxidant supplements for prevention of gastrointestinal cancers: a systematic review and meta-analysis. Lancet 2004;364:1219-1228. [PubMed: 15464182]

172. Clark LC, Hixson LJ, Combs GF Jr, Reid ME, Turnbull BW, Sampliner RE. Plasma selenium concentration predicts the prevalence of colorectal adenomatous polyps. Cancer Epidemiol Biomarkers Prev 1993;2:41-46. [PubMed: 8420611]

173. Connelly-Frost A, Poole C, Satia JA, Kupper LL, Millikan RC, Sandler RS. Selenium, apoptosis, and colorectal adenomas. Cancer Epidemiol Biomarkers Prev 2006;15:486-493. [PubMed: 16537706]

174. Jacobs ET, Jiang R, Alberts DS, Greenberg ER, Gunter EW, Karagas MR, Lanza E, Ratnasinghe L, Reid ME, Schatzkin A, Smith-Warner SA, Wallace K, Martinez ME. Selenium and colorectal adenoma: results of a pooled analysis. J Natl Cancer Inst 2004;96:1669-1675. [PubMed: 15547179]

175. Peters U, Chatterjee N, Church TR, Mayo C, Sturup S, Foster CB, Schatzkin A, Hayes RB. High serum selenium and reduced risk of advanced colorectal adenoma in a colorectal cancer early detection program. Cancer Epidemiol Biomarkers Prev 2006;15:315-320. [PubMed: 16492922]

176. Reid ME, Duffield-Lillico AJ, Sunga A, Fakih M, Alberts DS, Marshall JR. Selenium supplementation and colorectal adenomas: an analysis of the nutritional prevention of cancer trial. Int J Cancer 2006;118:1777-1781. [PubMed: 16217756]

177. Russo MW, Murray SC, Wurzelmann JI, Woosley JT, Sandler RS. Plasma selenium levels and the risk of colorectal adenomas. Nutr Cancer 1997;28:125-129. [PubMed: 9290116]

178. Clark LC, Combs GF Jr, Turnbull BW, Slate EH, Chalker DK, Chow J, Davis LS, Glover RA, Graham GF, Gross EG, Krongrad A, Lesher JL Jr, Park HK, Sanders BB Jr, Smith CL, Taylor JR. Effects of selenium supplementation for cancer prevention in patients with carcinoma of the skin. A randomized controlled trial. Nutritional Prevention of Cancer Study Group. JAMA 1996;276:1957-1963. [PubMed: 8971064]

179. Lippman SM, Klein EA, Goodman PJ, Lucia MS, Thompson IM, Ford LG, Parnes HL, Minasian LM, Gaziano JM, Hartline JA, Parsons JK, Bearden JD 3rd, Crawford ED, Goodman GE, Claudio J, Winquist E, Cook ED, Karp DD, Walther P, Lieber MM, Kristal AR, Darke AK, Arnold KB, Ganz PA, Santella RM, Albanes D, Taylor PR, Probstfield JL, Jagpal TJ, Crowley JJ, Meyskens FL Jr, Baker LH, Coltman CA Jr. Effect of selenium and vitamin E on risk of prostate cancer and other cancers: the Selenium and Vitamin E Cancer Prevention Trial (SELECT). JAMA 2009;301:39-51. [PubMed: 19066370]

180. The effect of vitamin $\mathrm{E}$ and beta carotene on the incidence of lung cancer and other cancers in male smokers. The Alpha-Tocopherol, Beta Carotene Cancer Prevention Study Group. N Engl J Med 1994;330:1029-1035. [PubMed: 8127329]

181. MacLennan R, Macrae F, Bain C, Battistutta D, Chapuis P, Gratten H, Lambert J, Newland RC, Ngu M, Russell A, et al. Randomized trial of intake of fat, fiber, and beta carotene to prevent colorectal adenomas. The Australian Polyp Prevention Project. J Natl Cancer Inst 1995;87:17601766. [PubMed: 7473832] 
182. Greenberg ER, Baron JA, Tosteson TD, Freeman DH Jr, Beck GJ, Bond JH, Colacchio TA, Coller JA, Frankl HD, Haile RW, et al. A clinical trial of antioxidant vitamins to prevent colorectal adenoma. Polyp Prevention Study Group. N Engl J Med 1994;331:141-147. [PubMed: 8008027]

183. Fung T, Hu FB, Fuchs C, Giovannucci E, Hunter DJ, Stampfer MJ, Colditz GA, Willett WC. Major dietary patterns and the risk of colorectal cancer in women. Arch Intern Med 2003;163:309-314. [PubMed: 12578511]

184. Dixon LB, Balder HF, Virtanen MJ, Rashidkhani B, Mannisto S, Krogh V, van Den Brandt PA, Hartman AM, Pietinen P, Tan F, Virtamo J, Wolk A, Goldbohm RA. Dietary patterns associated with colon and rectal cancer: results from the Dietary Patterns and Cancer (DIETSCAN) Project. Am J Clin Nutr 2004;80:1003-1011. [PubMed: 15447912]

185. Slattery ML, Boucher KM, Caan BJ, Potter JD, Ma KN. Eating patterns and risk of colon cancer. Am J Epidemiol 1998;148:4-16. [PubMed: 9663397]

186. Williams CD, Satia JA, Adair LS, Stevens J, Galanko J, Keku TO, Sandler RS. Dietary patterns, food groups, and rectal cancer risk in Whites and African-Americans. Cancer Epidemiol Biomarkers Prev 2009;18:1552-1561. [PubMed: 19423533]

187. Giovannucci E. Alcohol, one-carbon metabolism, and colorectal cancer: recent insights from molecular studies. J Nutr 2004;134 2475S-2481S.

188. Choi SY, Kahyo H. Effect of cigarette smoking and alcohol consumption in the etiology of cancers of the digestive tract. Int J Cancer 1991;49:381-386. [PubMed: 1917136]

189. Chyou PH, Nomura AM, Stemmermann GN. A prospective study of colon and rectal cancer among Hawaii Japanese men. Ann Epidemiol 1996;6:276-282. [PubMed: 8876837]

190. Ferraroni M, Negri E, La Vecchia C, D'Avanzo B, Franceschi S. Socioeconomic indicators, tobacco and alcohol in the aetiology of digestive tract neoplasms. Int J Epidemiol 1989;18:556-562. [PubMed: 2807657]

191. Freudenheim JL, Graham S, Marshall JR, Haughey BP, Wilkinson G. Lifetime alcohol intake and risk of rectal cancer in western New York. Nutr Cancer 1990;13:101-109. [PubMed: 2300490]

192. Hermann S, Rohrmann S, Linseisen J. Lifestyle factors, obesity and the risk of colorectal adenomas in EPIC-Heidelberg. Cancer Causes Control. 2009

193. Hirayama T. Association between alcohol consumption and cancer of the sigmoid colon: observations from a Japanese cohort study. Lancet 1989;2:725-727. [PubMed: 2570969]

194. Hu JF, Liu YY, Yu YK, Zhao TZ, Liu SD, Wang QQ. Diet and cancer of the colon and rectum: a case-control study in China. Int J Epidemiol 1991;20:362-367. [PubMed: 1917235]

195. Kabat GC, Howson CP, Wynder EL. Beer consumption and rectal cancer. Int J Epidemiol 1986;15:494-501. [PubMed: 3818156]

196. Klatsky AL, Armstrong MA, Friedman GD, Hiatt RA. The relations of alcoholic beverage use to colon and rectal cancer. Am J Epidemiol 1988;128:1007-1015. [PubMed: 3189277]

197. Kune S, Kune GA, Watson LF. Case-control study of alcoholic beverages as etiological factors: the Melbourne colorectal cancer study. Nutrition and Cancer 1987;9:43-56. [PubMed: 3808969]

198. Longnecker MP. A case-control study of alcoholic beverage consumption in relation to risk of cancer of the right colon and rectum in men. Cancer Causes Control 1990;1:5-14. [PubMed: 2102276]

199. Meyer F, White E. Alcohol and nutrients in relation to colon cancer in middle-aged adults. Am J Epidemiol 1993;138:225-236. [PubMed: 8395140]

200. Miller AB, Howe GR, Jain M, Craib KJ, Harrison L. Food items and food groups as risk factors in a case-control study of diet and colo-rectal cancer. Int J Cancer 1983;32:155-161. [PubMed: 6307893]

201. Murata M, Tagawa M, Watanabe S, Kimura H, Takeshita T, Morimoto K. Genotype difference of aldehyde dehydrogenase 2 gene in alcohol drinkers influences the incidence of Japanese colorectal cancer patients. Jpn J Cancer Res 1999;90:711-719. [PubMed: 10470282]

202. Newcomb PA, Storer BE, Marcus PM. Cancer of the large bowel in women in relation to alcohol consumption: a case-control study in Wisconsin (United States). Cancer Causes Control 1993;4:405-411. [PubMed: 8218871]

203. Peters RK, Garabrant DH, Yu MC, Mack TM. A case-control study of occupational and dietary factors in colorectal cancer in young men by subsite. Cancer Res 1989;49:5459-5468. [PubMed: 2766308] 
204. Peters RK, Pike MC, Garabrant D, Mack TM. Diet and colon cancer in Los Angeles County, California. Cancer Causes Control 1992;3:457-473. [PubMed: 1525327]

205. Pickle LW, Greene MH, Ziegler RG, Toledo A, Hoover R, Lynch HT, Fraumeni JF Jr. Colorectal cancer in rural Nebraska. Cancer Res 1984;44:363-369. [PubMed: 6690049]

206. Pollack ES, Nomura AM, Heilbrun LK, Stemmermann GN, Green SB. Prospective study of alcohol consumption and cancer. N Engl J Med 1984;310:617-621. [PubMed: 6694673]

207. Tuyns AJ, Pequignot G, Gignoux M, Valla A. Cancers of the digestive tract, alcohol and tobacco. Int J Cancer 1982;30:9-11. [PubMed: 7118300]

208. Williams RR, Horm JW. Association of cancer sites with tobacco and alcohol consumption and socioeconomic status of patients: interview study from the Third National Cancer Survey. J Natl Cancer Inst 1977;58:525-547. [PubMed: 557114]

209. Bidoli E, Franceschi S, Talamini R, Barra S, La Vecchia C. Food consumption and cancer of the colon and rectum in north-eastern Italy. Int J Cancer 1992;50:223-229. [PubMed: 1730516]

210. Le Marchand L, Wilkens LR, Kolonel LN, Hankin JH, Lyu L. Assocations of sedentary lifestyle, obesity, smoking, alcohol use and diabetes with the risk of colorectal cancer. Cancer Research 1997;57:4787-4794. [PubMed: 9354440]

211. Slattery ML, Schaffer D, Edwards SL, Ma KN, Potter JD. Are dietary factors involved in DNA methylation associated with colon cancer? Nutr Cancer 1997;28:52-62. [PubMed: 9200151]

212. Slattery ML, West DW, Robison LM, French TK, Ford MH, Schuman KL, Sorenson AW. Tobacco, alcohol, coffee, and caffeine as risk factors for colon cancer in a low-risk population. Epidemiology 1990;1:141-145. [PubMed: 2073501]

213. Giovannucci E, Rimm EB, Ascherio A, Stampfer MJ, Colditz GA, Willett WC. Alcohol, lowmethionine--low-folate diets, and risk of colon cancer in men. J Natl Cancer Inst 1995;87:265-273. [PubMed: 7707417]

214. Giovannucci E, Stampfer MJ, Colditz GA, Rimm EB, Trichopoulos D, Rosner BA, Speizer FE, Willett WC. Folate, methionine, and alcohol intake and risk of colorectal adenoma. J Natl Cancer Inst 1993;85:875-884. [PubMed: 8492316]

215. Cho E, Smith-Warner SA, Ritz J, van den Brandt PA, Colditz GA, Folsom AR, Freudenheim JL, Giovannucci E, Goldbohm RA, Graham S, Holmberg L, Kim DH, Malila N, Miller AB, Pietinen P, Rohan TE, Sellers TA, Speizer FE, Willett WC, Wolk A, Hunter DJ. Alcohol intake and colorectal cancer: a pooled analysis of 8 cohort studies. Ann Intern Med 2004;140:603-613. [PubMed: 15096331]

216. Ferrari P, Jenab M, Norat T, Moskal A, Slimani N, Olsen A, Tjonneland A, Overvad K, Jensen MK, Boutron-Ruault MC, Clavel-Chapelon F, Morois S, Rohrmann S, Linseisen J, Boeing H, Bergmann M, Kontopoulou D, Trichopoulou A, Kassapa C, Masala G, Krogh V, Vineis P, Panico S, Tumino R, van Gils CH, Peeters P, Bueno-de-Mesquita HB, Ocke MC, Skeie G, Lund E, Agudo A, Ardanaz E, Lopez DC, Sanchez MJ, Quiros JR, Amiano P, Berglund G, Manjer J, Palmqvist R, Van Guelpen B, Allen N, Key T, Bingham S, Mazuir M, Boffetta P, Kaaks R, Riboli E. Lifetime and baseline alcohol intake and risk of colon and rectal cancers in the European prospective investigation into cancer and nutrition (EPIC). Int J Cancer 2007;121:2065-2072. [PubMed: 17640039]

217. Bagnardi V, Blangiardo M, La Vecchia C, Corrao G. A meta-analysis of alcohol drinking and cancer risk. Br J Cancer 2001;85:1700-1705. [PubMed: 11742491]

218. Poynter JN, Haile RW, Siegmund KD, Campbell PT, Figueiredo JC, Limburg P, Young J, Le Marchand L, Potter JD, Cotterchio M, Casey G, Hopper JL, Jenkins MA, Thibodeau SN, Newcomb PA, Baron JA. Associations between smoking, alcohol consumption, and colorectal cancer, overall and by tumor microsatellite instability status. Cancer Epidemiol Biomarkers Prev 2009;18:27452750. [PubMed: 19755657]

219. Seitz HK, Simanowski UA, Garzon FT, Rideout JM, Peters TJ, Koch A, Berger MR, Einecke H, Maiwald M. Possible role of acetaldehyde in ethanol-related rectal cocarcinogenesis in the rat. Gastroenterology 1990;98:406-413. [PubMed: 2295396]

220. Choi SW, Stickel F, Baik HW, Kim YI, Seitz HK, Mason JB. Chronic alcohol consumption induces genomic but not p53-specific DNA hypomethylation in rat colon. J Nutr 1999;129:1945-1950. [PubMed: 10539767] 
221. Kune GA, Vitetta L. Alcohol consumption and the etiology of colorectal cancer: a review of the scientific evidence from 1957 to 1991. Nutr Cancer 1992;18:97-111. [PubMed: 1437657]

222. Doll R, Peto R. Mortality in relation to smoking: 20 years' observations on male British doctors. $\mathrm{Br}$ Med J 1976;2:1525-1536. [PubMed: 1009386]

223. Hammond EC, Horn D. Smoking and death rates: report on forty-four months of followup of 187,783 men. II. Death rates by cause. JAMA 1958;166:1294-1308.

224. Kahn HA. The Dorn study of smoking and mortality among U.S. veterans: report on eight and onehalf years of observation. Natl Cancer Inst Monogr 1966;19:1-125. [PubMed: 5905668]

225. Rogot E, Murray JL. Smoking and causes of death among US Veterans: 16 years of observation. Public Health Reports 1980;95:213-222. [PubMed: 7384406]

226. Giovannucci E, Colditz GA, Stampfer MJ, Hunter D, Rosner BA, Willett WC, Speizer FE. A prospective study of cigarette smoking and risk of colorectal adenoma and colorectal cancer in U.S. women. J Natl Cancer Inst 1994;86:192-199. [PubMed: 8283491]

227. Giovannucci E, Rimm EB, Stampfer MJ, Colditz GA, Ascherio A, Kearney J, Willett WC. A prospective study of cigarette smoking and risk of colorectal adenoma and colorectal cancer in U.S. men. J Natl Cancer Inst 1994;86:183-191. [PubMed: 8283490]

228. Anonymous. Tobacco smoking. IARC Monographs on the Evaluation of Carcinogenic Risks to Humans 1986;38:397.

229. Yamasaki E, Ames BN. Concentration of mutagens from urine by absorption with the nonpolar resin XAD-2: cigarette smokers have mutagenic urine. Proceedings of the National Academy of Sciences of the United States of America 1977;74:3555-3559. [PubMed: 333441]

230. Giovannucci E. An updated review of the epidemiological evidence that cigarette smoking increases risk of colorectal cancer. Cancer Epidemiology, Biomarkers and Prevention 2001;10:725-731.

231. Botteri E, Iodice S, Raimondi S, Maisonneuve P, Lowenfels AB. Cigarette smoking and adenomatous polyps: a meta-analysis. Gastroenterology 2008;134:388-395. [PubMed: 18242207]

232. Botteri E, Iodice S, Bagnardi V, Raimondi S, Lowenfels AB, Maisonneuve P. Smoking and colorectal cancer: a meta-analysis. JAMA 2008;300:2765-2778. [PubMed: 19088354]

233. Liang PS, Chen TY, Giovannucci E. Cigarette smoking and colorectal cancer incidence and mortality: systematic review and meta-analysis. Int J Cancer 2009;124:2406-2415. [PubMed: 19142968]

234. Tsoi KK, Pau CY, Wu WK, Chan FK, Griffiths S, Sung JJ. Cigarette smoking and the risk of colorectal cancer: a meta-analysis of prospective cohort studies. Clin Gastroenterol Hepatol 2009;7:682-688. e1-5. [PubMed: 19245853]

235. Hannan LM, Jacobs EJ, Thun MJ. The association between cigarette smoking and risk of colorectal cancer in a large prospective cohort from the United States. Cancer Epidemiol Biomarkers Prev 2009;18:3362-3367. [PubMed: 19959683]

236. Limburg PJ, Vierkant RA, Cerhan JR, Yang P, Lazovich D, Potter JD, Sellers TA. Cigarette smoking and colorectal cancer: long-term, subsite-specific risks in a cohort study of post-menopausal women. Clinical Gastroenterology and Hepatology 2003;1:202-210. [PubMed: 15017492]

237. Chao A, Thun MJ, Jacobs EJ, Henley SJ, Rodriguez C, Calle EE. Cigarette smoking and colorectal cancer mortality in the cancer prevention study II. J Natl Cancer Inst 2000;92:1888-1896. [PubMed: 11106680]

238. Heineman EF, Zahm SH, McLaughlin JK, Vaught JB. Increased risk of colorectal cancer among smokers: results of a 26-year follow-up of US veterans and a review. Int J Cancer 1994;59:728738. [PubMed: 7989109]

239. Newcomb PA, Storer BE, Marcus PM. Cigarette smoking in relation to risk of large bowel cancer in women. Cancer Res 1995;55:4906-4909. [PubMed: 7585528]

240. Abrams JA, Terry MB, Neugut AI. Cigarette smoking and the colorectal adenoma-carcinoma sequence. Gastroenterology 2008;134:617-619. [PubMed: 18242224]

241. Lee IM, Paffenbarger RS Jr, Hsieh CC. Physical activity and risk of developing colorectal cancer among college alumni. J Natl Cancer Inst 1991;83:1324-1329. [PubMed: 1886158]

242. Giovannucci E, Ascherio A, Rimm EB, Colditz GA, Stampfer MJ, Willett WC. Physical activity, obesity, and risk for colon cancer and adenoma in men. Ann Intern Med 1995;122:327-334. [PubMed: 7847643] 
243. Martinez ME, Giovannucci E, Spiegelman D, Hunter DJ, Willett WC, Colditz GA. Leisure-time physical activity, body size, and colon cancer in women. Nurses' Health Study Research Group. J Natl Cancer Inst 1997;89:948-955. [PubMed: 9214674]

244. Pischon T, Lahmann PH, Boeing H, Friedenreich C, Norat T, Tjonneland A, Halkjaer J, Overvad K, Clavel-Chapelon F, Boutron-Ruault MC, Guernec G, Bergmann MM, Linseisen J, Becker N, Trichopoulou A, Trichopoulos D, Sieri S, Palli D, Tumino R, Vineis P, Panico S, Peeters PH, Buenode-Mesquita HB, Boshuizen HC, Van Guelpen B, Palmqvist R, Berglund G, Gonzalez CA, Dorronsoro M, Barricarte A, Navarro C, Martinez C, Quiros JR, Roddam A, Allen N, Bingham S, Khaw KT, Ferrari P, Kaaks R, Slimani N, Riboli E. Body size and risk of colon and rectal cancer in the European Prospective Investigation Into Cancer and Nutrition (EPIC). J Natl Cancer Inst 2006;98:920-931. [PubMed: 16818856]

245. Giovannucci E, Colditz GA, Stampfer MJ, Willett WC. Physical activity, obesity, and risk of colorectal adenoma in women (United States). Cancer Causes Control 1996;7:253-263. [PubMed: 8740738]

246. Ning Y, Wang L, Giovannucci EL. A quantitative analysis of body mass index and colorectal cancer: findings from 56 observational studies. Obes Rev. 2009

247. Larsson SC, Wolk A. Obesity and colon and rectal cancer risk: a meta-analysis of prospective studies. Am J Clin Nutr 2007;86:556-565. [PubMed: 17823417]

248. Giovannucci E. Insulin and colon cancer. Cancer Causes Control 1995;6:164-179. [PubMed: 7749056]

249. Ma J, Giovannucci E, Pollak M, Leavitt A, Tao Y, Gaziano JM, Stampfer MJ. A prospective study of plasma C-peptide and colorectal cancer risk in men. J Natl Cancer Inst 2004;96:546-553. [PubMed: 15069117]

250. Saydah SH, Platz EA, Rifai N, Pollak MN, Brancati FL, Helzlsouer KJ. Association of markers of insulin and glucose control with subsequent colorectal cancer risk. Cancer Epidemiol Biomarkers Prev 2003;12:412-418. [PubMed: 12750235]

251. Jenab M, Riboli E, Cleveland RJ, Norat T, Rinaldi S, Nieters A, Biessy C, Tjonneland A, Olsen A, Overvad K, Gronbaek H, Clavel-Chapelon F, Boutron-Ruault MC, Linseisen J, Boeing H, Pischon T, Trichopoulos D, Oikonomou E, Trichopoulou A, Panico S, Vineis P, Berrino F, Tumino R, Masala G, Peters PH, van Gils CH, Bueno-de-Mesquita HB, Ocke MC, Lund E, Mendez MA, Tormo MJ, Barricarte A, Martinez-Garcia C, Dorronsoro M, Quiros JR, Hallmans G, Palmqvist R, Berglund G, Manjer J, Key T, Allen NE, Bingham S, Khaw KT, Cust A, Kaaks R. Serum C-peptide, IGFBP-1 and IGFBP-2 and risk of colon and rectal cancers in the European Prospective Investigation into Cancer and Nutrition. Int J Cancer 2007;121:368-376. [PubMed: 17372899]

252. Kaaks R, Toniolo P, Akhmedkhanov A, Lukanova A, Biessy C, Dechaud H, Rinaldi S, ZeleniuchJacquotte A, Shore RE, Riboli E. Serum C-peptide, insulin-like growth factor (IGF)-I, IGF-binding proteins, and colorectal cancer risk in women. J Natl Cancer Inst 2000;92:1592-1600. [PubMed: 11018095]

253. Otani T, Iwasaki M, Sasazuki S, Inoue M, Tsugane S. Plasma C-peptide, insulin-like growth factorI, insulin-like growth factor binding proteins and risk of colorectal cancer in a nested case-control study: the Japan public health center-based prospective study. Int J Cancer 2007;120:2007-2012. [PubMed: 17266031]

254. Stocks T, Lukanova A, Johansson M, Rinaldi S, Palmqvist R, Hallmans G, Kaaks R, Stattin P. Components of the metabolic syndrome and colorectal cancer risk; a prospective study. Int J Obes (Lond). 2007

255. Wei EK, Ma J, Pollak MN, Rifai N, Fuchs CS, Hankinson SE, Giovannucci E. A prospective study of C-peptide, insulin-like growth factor-I, insulin-like growth factor binding protein-1, and the risk of colorectal cancer in women. Cancer Epidemiol Biomarkers Prev 2005;14:850-855. [PubMed: 15824155]

256. Wei EK, Giovannucci E, Fuchs CS, Willett WC, Mantzoros CS. Low plasma adiponectin levels and risk of colorectal cancer in men: a prospective study. J Natl Cancer Inst 2005;97:1688-1694. [PubMed: 16288122]

257. Otake S, Takeda H, Suzuki Y, Fukui T, Watanabe S, Ishihama K, Saito T, Togashi H, Nakamura T, Matsuzawa Y, Kawata S. Association of visceral fat accumulation and plasma adiponectin with 
colorectal adenoma: evidence for participation of insulin resistance. Clin Cancer Res 2005; 11:36423646. [PubMed: 15897559]

258. Hu FB, Manson JE, Liu S, Hunter D, Colditz GA, Michels KB, Speizer FE, Giovannucci E. Prospective study of adult onset diabetes mellitus (type 2) and risk of colorectal cancer in women. J Natl Cancer Inst 1999;91:542-547. [PubMed: 10088625]

259. Larsson SC, Giovannucci E, Wolk A. Diabetes and colorectal cancer incidence in the cohort of Swedish men. Diabetes Care 2005;28:1805-1807. [PubMed: 15983343]

260. La Vecchia C, Negri E, Decarli A, Franceschi S. Diabetes mellitus and colorectal cancer risk. Cancer Epidemiol Biomarkers Prev 1997;6:1007-1010. [PubMed: 9419395]

261. Limburg PJ, Anderson KE, Johnson TW, Jacobs DR Jr, Lazovich D, Hong CP, Nicodemus KK, Folsom AR. Diabetes mellitus and subsite-specific colorectal cancer risks in the Iowa Women's Health Study. Cancer Epidemiol Biomarkers Prev 2005;14:133-137. [PubMed: 15668486]

262. Limburg PJ, Vierkant RA, Fredericksen ZS, Leibson CL, Rizza RA, Gupta AK, Ahlquist DA, Melton LJ 3rd, Sellers TA, Cerhan JR. Clinically confirmed type 2 diabetes mellitus and colorectal cancer risk: a population-based, retrospective cohort study. Am J Gastroenterol 2006;101:1872-1879. [PubMed: 16790032]

263. Rinaldi S, Rohrmann S, Jenab M, Biessy C, Sieri S, Palli D, Tumino R, Mattiello A, Vineis P, Nieters A, Linseisen J, Pischon T, Boeing H, Hallmans G, Palmqvist R, Manjer J, Wirfalt E, Crowe FL, Khaw KT, Bingham S, Tjonneland A, Olsen A, Overvad K, Lund E, Skeie G, Clavel-Chapelon F, Boutron-Ruault MC, de Lauzon-Guillain B, Ardanaz E, Jakszyn P, Ramon Quiros J, Chirlaque MD, Sanchez MJ, Dorronsoro M, Trichopoulou A, Lagiou P, Trichopoulos D, Bueno-de-Mesquita HB, van Duijnhoven FJ, Peeters PH, Slimani N, Ferrari P, Byrnes GB, Riboli E, Kaaks R. Glycosylated hemoglobin and risk of colorectal cancer in men and women, the European prospective investigation into cancer and nutrition. Cancer Epidemiol Biomarkers Prev 2008;17:3108-3115. [PubMed: 18990751]

264. Khaw KT, Wareham N, Bingham S, Luben R, Welch A, Day N. Preliminary communication: glycated hemoglobin, diabetes, and incident colorectal cancer in men and women: a prospective analysis from the European prospective investigation into cancer-Norfolk study. Cancer Epidemiol Biomarkers Prev 2004;13:915-919. [PubMed: 15184246]

265. Lin J, Ridker PM, Pradhan A, Lee IM, Manson JE, Cook NR, Buring JE, Zhang SM. Hemoglobin A1c concentrations and risk of colorectal cancer in women. Cancer Epidemiol Biomarkers Prev 2005;14:3010-3012. [PubMed: 16365028]

266. Platz EA, Hankinson SE, Rifai N, Colditz GA, Speizer FE, Giovannucci E. Glycosylated hemoglobin and risk of colorectal cancer and adenoma (United States). Cancer Causes Control 1999;10:379386. [PubMed: 10530607]

267. Wei EK, Ma J, Pollak MN, Rifai N, Fuchs CS, Hankinson SE, Giovannucci E. C-peptide, insulinlike growth factor binding protein-1, glycosylated hemoglobin, and the risk of distal colorectal adenoma in women. Cancer Epidemiol Biomarkers Prev 2006;15:750-755. [PubMed: 16614119]

268. Shoelson SE, Herrero L, Naaz A. Obesity, inflammation, and insulin resistance. Gastroenterology 2007;132:2169-2180. [PubMed: 17498510]

269. Kim S, Keku TO, Martin C, Galanko J, Woosley JT, Schroeder JC, Satia JA, Halabi S, Sandler RS. Circulating levels of inflammatory cytokines and risk of colorectal adenomas. Cancer Res 2008;68:323-328. [PubMed: 18172326]

270. Hotamisligil GS. Inflammation and metabolic disorders. Nature 2006;444:860-867. [PubMed: 17167474]

271. Slattery ML, Samowitz W, Hoffman M, Ma KN, Levin TR, Neuhausen S. Aspirin, NSAIDs, and colorectal cancer: possible involvement in an insulin-related pathway. Cancer Epidemiol Biomarkers Prev 2004;13:538-545. [PubMed: 15066917]

272. Delage B, Rullier A, Capdepont M, Rullier E, Cassand P. The effect of body weight on altered expression of nuclear receptors and cyclooxygenase-2 in human colorectal cancers. Nutr J 2007;6:20. [PubMed: 17767717]

273. Kim S, Baron JA, Mott LA, Burke CA, Church TR, McKeown-Eyssen GE, Cole BF, Haile RW, Sandler RS. Aspirin may be more effective in preventing colorectal adenomas in patients with higher BMI (United States). Cancer Causes Control 2006;17:1299-1304. [PubMed: 17111262] 
274. Colbert LH, Hartman TJ, Malila N, Limburg PJ, Pietinen P, Virtamo J, Taylor PR, Albanes D. Physical activity in relation to cancer of the colon and rectum in a cohort of male smokers. Cancer Epidemiol Biomarkers Prev 2001;10:265-268. [PubMed: 11303597]

275. Colditz G, Cannuscio C, Frazier A. Physical activity and reduced risk of colon cancer: implications for prevention. Cancer Causes Control 1997;8:649-667. [PubMed: 9242482]

276. Kono S, Shinchi K, Ikeda N, Yanai F, Imanishi K. Physical activity, dietary habits and adenomatous polyps of the sigmoid colon: a study of self-defense officials in Japan. Journal of Clinical Epidemiology 1991;44:1255-1261. [PubMed: 1941019]

277. Neugut AI, Terry MB, Hocking G, Mosca L, Garbowski GC, Forde KA, Treat MR, Waye J. Leisure and occupational physical activity and risk of colorectal adenomatous polyps. International Journal of Cancer 1996;68:744-748.

278. Thun MJ, Calle EE, Namboodiri MM, Flanders WD, Coates RJ, Byers T, Boffetta P, Garfinkel L, Heath CW Jr. Risk factors for fatal colon cancer in a large prospective study. J Natl Cancer Inst 1992;84:1491-1500. [PubMed: 1433333]

279. Martinez ME, Giovannucci E, Spiegelman D, Stampfer MJ, Hunter DJ, Speizer FE, Willett WC, Colditz GA. Physical activity, body size, and colorectal cancer in women. Am J Epidemiol 1996;143:S73.

280. Slattery ML, Potter J, Caan B, Edwards S, Coates A, Ma K-N, Berry TD. Energy balance and colon cancer--beyond physical activity. Cancer Res 1997;57:75-80. [PubMed: 8988044]

281. Wolin KY, Yan Y, Colditz GA, Lee IM. Physical activity and colon cancer prevention: a metaanalysis. Br J Cancer 2009;100:611-616. [PubMed: 19209175]

282. Dowse GK, Zimmet PZ, Gareeboo H, George K, Alberti MM, Tuomilehto J, Finch CF, Chitson P, Tulsidas H. Abdominal obesity and physical inactivity as risk factors for NIDDM and impaired glucose tolerance in Indian, Creole, and Chinese Mauritians. Diabetes Care 1991;14:271-282. [PubMed: 2060430]

283. Regensteiner JG, Mayer EJ, Shetterly SM, Eckel RH, Haskell WL, Marshall JA, Baxter J, Hamman RF. Relationship between habitual physical activity and insulin levels among nondiabetic men and women. San Luis Valley Diabetes Study. Diabetes Care 1991;14:1066-1074. [PubMed: 1797488]

284. Breuer-Katschinski B, Nemes K, Rump B, Leiendecker B, Marr A, Breuer N, Goebell H. Long-term use of nonsteroidal antiinflammatory drugs and the risk of colorectal adenomas. The Colorectal Adenoma Study Group. Digestion 2000;61:129-134. [PubMed: 10705177]

285. Coogan PF, Rosenberg L, Louik C, Zauber AG, Stolley PD, Strom BL, Shapiro S. NSAIDs and risk of colorectal cancer according to presence or absence of family history of the disease. Cancer Causes Control 2000;11:249-255. [PubMed: 10782659]

286. Friedman GD, Coates AO, Potter JD, Slattery ML. Drugs and colon cancer. Pharmacoepidemiol Drug Saf 1998;7:99-106. [PubMed: 15073733]

287. Friis S, Poulsen AH, Sorensen HT, Tjonneland A, Overvad K, Vogel U, McLaughlin JK, Blot WJ, Olsen JH. Aspirin and other non-steroidal anti-inflammatory drugs and risk of colorectal cancer: a Danish cohort study. Cancer Causes Control 2009;20:731-740. [PubMed: 19122977]

288. Friis S, Sorensen HT, McLaughlin JK, Johnsen SP, Blot WJ, Olsen JH. A population-based cohort study of the risk of colorectal and other cancers among users of low-dose aspirin. Br J Cancer 2003;88:684-688. [PubMed: 12618874]

289. Garcia Rodriguez LA, Huerta-Alvarez C. Reduced incidence of colorectal adenoma among longterm users of nonsteroidal antiinflammatory drugs: a pooled analysis of published studies and a new population-based study. Epidemiology 2000;11:376-381. [PubMed: 10874542]

290. Garcia-Rodriguez LA, Huerta-Alvarez C. Reduced risk of colorectal cancer among long-term users of aspirin and nonaspirin nonsteroidal antiinflammatory drugs. Epidemiology 2001;12:471-472.

291. Grau MV, Sandler RS, McKeown-Eyssen G, Bresalier RS, Haile RW, Barry EL, Ahnen DJ, Gui J, Summers RW, Baron JA. Nonsteroidal anti-inflammatory drug use after 3 years of aspirin use and colorectal adenoma risk: observational follow-up of a randomized study. J Natl Cancer Inst 2009;101:267-276. [PubMed: 19211442]

292. Jacobs EJ, Thun MJ, Bain EB, Rodriguez C, Henley SJ, Calle EE. A large cohort study of long-term daily use of adult-strength aspirin and cancer incidence. J Natl Cancer Inst 2007;99:608-615. [PubMed: 17440162] 
293. Juarranz M, Calle-Puron ME, Gonzalez-Navarro A, Regidor-Poyatos E, Soriano T, MartinezHernandez D, Rojas VD, Guinee VF. Physical exercise, use of Plantago ovata and aspirin, and reduced risk of colon cancer. Eur J Cancer Prev 2002;11:465-472. [PubMed: 12394244]

294. Kahn HS, Tatham LM, Thun MJ, Heath CW Jr. Risk factors for self-reported colon polyps. J Gen Intern Med 1998;13:303-310. [PubMed: 9613885]

295. La Vecchia C, Negri E, Franceschi S, Conti E, Montella M, Giacosa A, Falcini A, Decarli A. Aspirin and colorectal cancer. Br J Cancer 1997;76:675-677. [PubMed: 9303370]

296. Morimoto LM, Newcomb PA, Ulrich CM, Bostick RM, Lais CJ, Potter JD. Risk factors for hyperplastic and adenomatous polyps: evidence for malignant potential? Cancer Epidemiol Biomarkers Prev 2002;11:1012-1018. [PubMed: 12376501]

297. Sandler RS, Galanko JC, Murray SC, Helm JF, Woosley JT. Aspirin and nonsteroidal antiinflammatory agents and risk for colorectal adenomas. Gastroenterology 1998;114:441-447. [PubMed: 9496933]

298. Sorensen HT, Friis S, Norgard B, Mellemkjaer L, Blot WJ, McLaughlin JK, Ekbom A, Baron JA. Risk of cancer in a large cohort of nonaspirin NSAID users: a population-based study. Br J Cancer 2003;88:1687-1692. [PubMed: 12771981]

299. Tangrea JA, Albert PS, Lanza E, Woodson K, Corle D, Hasson M, Burt R, Caan B, Paskett E, Iber F, Kikendall JW, Lance P, Shike M, Weissfeld J, Schatzkin A. Non-steroidal anti-inflammatory drug use is associated with reduction in recurrence of advanced and non-advanced colorectal adenomas (United States). Cancer Causes Control 2003;14:403-411. [PubMed: 12946034]

300. Cruz-Correa M, Hylind LM, Romans KE, Booker SV, Giardiello FM. Long-term treatment with sulindac in familial adenomatous polyposis: a prospective cohort study. Gastroenterology 2002;122:641-645. [PubMed: 11874996]

301. Giardiello FM, Hamilton SR, Krush AJ, Piantadosi S, Hylind LM, Celano P, Booker SV, Robinson CR, Offerhaus GJ. Treatment of colonic and rectal adenomas with sulindac in familial adenomatous polyposis. N Engl J Med 1993;328:1313-1316. [PubMed: 8385741]

302. Hallak A, Alon-Baron L, Shamir R, Moshkowitz M, Bulvik B, Brazowski E, Halpern Z, Arber N. Rofecoxib reduces polyp recurrence in familial polyposis. Dig Dis Sci 2003;48:1998-2002. [PubMed: 14627347]

303. Labayle D, Fischer D, Vielh P, Drouhin F, Pariente A, Bories C, Duhamel O, Trousset M, Attali P. Sulindac causes regression of rectal polyps in familial adenomatous polyposis. Gastroenterology 1991;101:635-639. [PubMed: 1650315]

304. Rigau J, Pique JM, Rubio E, Planas R, Tarrech JM, Bordas JM. Effects of long-term sulindac therapy on colonic polyposis. Ann Intern Med 1991;115:952-954. [PubMed: 1659272]

305. Steinbach G, Lynch PM, Phillips RK, Wallace MH, Hawk E, Gordon GB, Wakabayashi N, Saunders B, Shen Y, Fujimura T, Su LK, Levin B. The effect of celecoxib, a cyclooxygenase-2 inhibitor, in familial adenomatous polyposis. New England Journal of Medicine 2000;342:1946-1952. [PubMed: 10874062]

306. Waddell WR, Ganser GF, Cerise EJ, Loughry RW. Sulindac for polyposis of the colon. Am J Surg 1989;157:175-179. [PubMed: 2535920]

307. Waddell WR, Loughry RW. Sulindac for polyposis of the colon. J Surg Oncol 1983;24:83-87. [PubMed: 6887943]

308. Baron JA, Cole BF, Sandler RS, Haile RW, Ahnen D, Bresalier R, McKeown-Eyssen G, Summers RW, Rothstein R, Burke CA, Snover DC, Church TR, Allen JI, Beach M, Beck GJ, Bond JH, Byers T, Greenberg ER, Mandel JS, Marcon N, Mott LA, Pearson L, Saibil F, van Stolk RU. A randomized trial of aspirin to prevent colorectal adenomas. N Engl J Med 2003;348:891-899. [PubMed: 12621133]

309. Benamouzig R, Deyra J, Martin A, Girard B, Jullian E, Piednoir B, Couturier D, Coste T, Little J, Chaussade S. Daily soluble aspirin and prevention of colorectal adenoma recurrence: one-year results of the APACC trial. Gastroenterology 2003;125:328-336. [PubMed: 12891533]

310. Sandler RS, Halabi S, Baron JA, Budinger S, Paskett E, Keresztes R, Petrelli N, Pipas JM, Karp DD, Loprinzi CL, Steinbach G, Schilsky R. A randomized trial of aspirin to prevent colorectal adenomas in patients with previous colorectal cancer. N Engl J Med 2003;348:883-890. [PubMed: 12621132] 
311. Cole BF, Logan RF, Halabi S, Benamouzig R, Sandler RS, Grainge MJ, Chaussade S, Baron JA. Aspirin for the chemoprevention of colorectal adenomas: meta-analysis of the randomized trials. $\mathbf{J}$ Natl Cancer Inst 2009;101:256-266. [PubMed: 19211452]

312. Cook NR, Lee IM, Gaziano JM, Gordon D, Ridker PM, Manson JE, Hennekens CH, Buring JE. Low-dose aspirin in the primary prevention of cancer: the Women's Health Study: a randomized controlled trial. Jama 2005;294:47-55. [PubMed: 15998890]

313. Gann PH, Manson JE, Glynn RJ, Buring JE, Hennekens CH. Low-dose aspirin and incidence of colorectal tumors in a randomized trial. J Natl Cancer Inst 1993;85:1220-1224. [PubMed: 8331682]

314. Chan AT, Giovannucci EL, Meyerhardt JA, Schernhammer ES, Wu K, Fuchs CS. Aspirin dose and duration of use and risk of colorectal cancer in men. Gastroenterology 2008;134:21-28. [PubMed: 18005960]

315. Chan AT, Giovannucci EL, Meyerhardt JA, Schernhammer ES, Curhan GC, Fuchs CS. Long-term use of aspirin and nonsteroidal anti-inflammatory drugs and risk of colorectal cancer. Jama 2005;294:914-923. [PubMed: 16118381]

316. Flossmann E, Rothwell PM. Effect of aspirin on long-term risk of colorectal cancer: consistent evidence from randomised and observational studies. Lancet 2007;369:1603-1613. [PubMed: 17499602]

317. Chan AT, Giovannucci EL, Schernhammer ES, Colditz GC, Hunter DJ, Willett WC, Fuchs CS. A prospective study of aspirin use and the risk of colorectal adenoma. Ann Intern Med 2004;140:157166. [PubMed: 14757613]

318. Chan AT, Tranah GJ, Giovannucci EL, Hunter DJ, Fuchs CS. Genetic variants in the UGT1A6 enzyme, aspirin use, and the risk of colorectal adenoma. J Natl Cancer Inst 2005;97:457-460. [PubMed: 15770010]

319. Bigler J, Whitton J, Lampe JW, Fosdick L, Bostick RM, Potter JD. CYP2C9 and UGT1A6 genotypes modulate the protective effect of aspirin on colon adenoma risk. Cancer Res 2001;61:3566-3569. [PubMed: 11325819]

320. Arber N, Eagle CJ, Spicak J, Racz I, Dite P, Hajer J, Zavoral M, Lechuga MJ, Gerletti P, Tang J, Rosenstein RB, Macdonald K, Bhadra P, Fowler R, Wittes J, Zauber AG, Solomon SD, Levin B. Celecoxib for the prevention of colorectal adenomatous polyps. N Engl J Med 2006;355:885-895. [PubMed: 16943401]

321. Baron JA, Sandler RS, Bresalier RS, Quan H, Riddell R, Lanas A, Bolognese JA, Oxenius B, Horgan K, Loftus S, Morton DG. A randomized trial of rofecoxib for the chemoprevention of colorectal adenomas. Gastroenterology 2006;131:1674-1682. [PubMed: 17087947]

322. Bertagnolli MM, Eagle CJ, Zauber AG, Redston M, Solomon SD, Kim K, Tang J, Rosenstein RB, Wittes J, Corle D, Hess TM, Woloj GM, Boisserie F, Anderson WF, Viner JL, Bagheri D, Burn J, Chung DC, Dewar T, Foley TR, Hoffman N, Macrae F, Pruitt RE, Saltzman JR, Salzberg B, Sylwestrowicz T, Gordon GB, Hawk ET. Celecoxib for the prevention of sporadic colorectal adenomas. N Engl J Med 2006;355:873-884. [PubMed: 16943400]

323. Baron JA, Sandler RS, Bresalier RS, Lanas A, Morton DG, Riddell R, Iverson ER, Demets DL. Cardiovascular events associated with rofecoxib: final analysis of the APPROVe trial. Lancet 2008;372:1756-1764. [PubMed: 18922570]

324. Bresalier RS, Sandler RS, Quan H, Bolognese JA, Oxenius B, Horgan K, Lines C, Riddell R, Morton D, Lanas A, Konstam MA, Baron JA. Cardiovascular Events Associated with Rofecoxib in a Colorectal Adenoma Chemoprevention Trial. N Engl J Med 2005;352:1092-1102. [PubMed: 15713943]

325. Solomon SD, McMurray JJ, Pfeffer MA, Wittes J, Fowler R, Finn P, Anderson WF, Zauber A, Hawk E, Bertagnolli M. Cardiovascular Risk Associated with Celecoxib in a Clinical Trial for Colorectal Adenoma Prevention. N Engl J Med 2005;352:1071-1080. [PubMed: 15713944]

326. Solomon SD, Pfeffer MA, McMurray JJ, Fowler R, Finn P, Levin B, Eagle C, Hawk E, Lechuga M, Zauber AG, Bertagnolli MM, Arber N, Wittes J. Effect of celecoxib on cardiovascular events and blood pressure in two trials for the prevention of colorectal adenomas. Circulation 2006;114:1028-1035. [PubMed: 16943394]

327. Solomon SD, Wittes J, Finn PV, Fowler R, Viner J, Bertagnolli MM, Arber N, Levin B, Meinert CL, Martin B, Pater JL, Goss PE, Lance P, Obara S, Chew EY, Kim J, Arndt G, Hawk E. 
Cardiovascular risk of celecoxib in 6 randomized placebo-controlled trials: the cross trial safety analysis. Circulation 2008;117:2104-2113. [PubMed: 18378608]

328. Bertagnolli MM, Eagle CJ, Zauber AG, Redston M, Breazna A, Kim K, Tang J, Rosenstein RB, Umar A, Bagheri D, Collins NT, Burn J, Chung DC, Dewar T, Foley TR, Hoffman N, Macrae F, Pruitt RE, Saltzman JR, Salzberg B, Sylwestrowicz T, Hawk ET. Five-year efficacy and safety analysis of the Adenoma Prevention with Celecoxib Trial. Cancer Prev Res (Phila Pa) 2009;2:310 321.

329. Chan AO, Jim MH, Lam KF, Morris JS, Siu DC, Tong T, Ng FH, Wong SY, Hui WM, Chan CK, Lai KC, Cheung TK, Chan P, Wong G, Yuen MF, Lau YK, Lee S, Szeto ML, Wong BC, Lam SK. Prevalence of colorectal neoplasm among patients with newly diagnosed coronary artery disease. Jama 2007;298:1412-1419. [PubMed: 17895457]

330. Boyapati SM, Bostick RM, McGlynn KA, Fina MF, Roufail WM, Geisinger KR, Wargovich M, Coker A, Hebert JR. Calcium, vitamin D, and risk for colorectal adenoma: dependency on vitamin D receptor BsmI polymorphism and nonsteroidal anti-inflammatory drug use? Cancer Epidemiol Biomarkers Prev 2003;12:631-637. [PubMed: 12869402]

331. Collet JP, Sharpe C, Belzile E, Boivin JF, Hanley J, Abenhaim L. Colorectal cancer prevention by non-steroidal anti-inflammatory drugs: effects of dosage and timing. Br J Cancer 1999;81:62-68. [PubMed: 10487613]

332. Hauret KG, Bostick RM, Matthews CE, Hussey JR, Fina MF, Geisinger KR, Roufail WM. Physical activity and reduced risk of incident sporadic colorectal adenomas: observational support for mechanisms involving energy balance and inflammation modulation. Am J Epidemiol 2004;159:983-992. [PubMed: 15128611]

333. Kim S, Martin C, Galanko J, Woosley JT, Schroeder JC, Keku TO, Satia JA, Halabi S, Sandler RS. Use of nonsteroidal antiinflammatory drugs and distal large bowel cancer in whites and African Americans. Am J Epidemiol 2008;168:1292-1300. [PubMed: 18945689]

334. Kune GA, Kune S, Watson LF. Colorectal cancer risk, chronic illnesses, operations, and medications: case control results from the Melbourne Colorectal Cancer Study. Cancer Res 1988;48:4399-4404. [PubMed: 3390835]

335. Lieberman DA, Prindiville S, Weiss DG, Willett W. Risk factors for advanced colonic neoplasia and hyperplastic polyps in asymptomatic individuals. Jama 2003;290:2959-2967. [PubMed: 14665657]

336. Lipworth L, Friis S, Blot WJ, McLaughlin JK, Mellemkjaer L, Johnsen SP, Norgaard B, Olsen JH. A population-based cohort study of mortality among users of ibuprofen in Denmark. Am J Ther 2004;11:156-163. [PubMed: 15133529]

337. Logan RF, Little J, Hawtin PG, Hardcastle JD. Effect of aspirin and non-steroidal anti-inflammatory drugs on colorectal adenomas: case-control study of subjects participating in the Nottingham faecal occult blood screening programme. BMJ 1993;307:285-289. [PubMed: 8374373]

338. Martin C, Connelly A, Keku TO, Mountcastle SB, Galanko J, Woosley JT, Schliebe B, Lund PK, Sandler RS. Nonsteroidal anti-inflammatory drugs, apoptosis, and colorectal adenomas. Gastroenterology 2002;123:1770-1777. [PubMed: 12454832]

339. Martinez ME, McPherson RS, Levin B, Annegers JF. Aspirin and other nonsteroidal antiinflammatory drugs and risk of colorectal adenomatous polyps among endoscoped individuals. Cancer Epidemiol Biomarkers Prev 1995;4:703-707. [PubMed: 8672985]

340. Muscat JE, Stellman SD, Wynder EL. Nonsteroidal antiinflammatory drugs and colorectal cancer. Cancer 1994;74:1847-1854. [PubMed: 8082089]

341. Peleg II, Lubin MF, Cotsonis GA, Clark WS, Wilcox CM. Long-term use of nonsteroidal antiinflammatory drugs and other chemopreventors and risk of subsequent colorectal neoplasia. Dig Dis Sci 1996;41:1319-1326. [PubMed: 8689906]

342. Reeves MJ, Newcomb PA, Trentham-Dietz A, Storer BE, Remington PL. Nonsteroidal antiinflammatory drug use and protection against colorectal cancer in women. Cancer Epidemiol Biomarkers Prev 1996;5:955-960. [PubMed: 8959316]

343. Sansbury LB, Millikan RC, Schroeder JC, Moorman PG, North KE, Sandler RS. Use of nonsteroidal antiinflammatory drugs and risk of colon cancer in a population-based, case-control study of African Americans and Whites. Am J Epidemiol 2005;162:548-558. [PubMed: 16093288] 
344. Sansbury LB, Millikan RC, Schroeder JC, North KE, Moorman PG, Keku TO, de Cotret AR, Player J, Sandler RS. COX-2 polymorphism, use of nonsteroidal anti-inflammatory drugs, and risk of colon cancer in African Americans (United States). Cancer Causes Control 2006;17:257-266. [PubMed: 16489533]

345. Shadman M, Newcomb PA, Hampton JM, Wernli KJ, Trentham-Dietz A. Non-steroidal antiinflammatory drugs and statins in relation to colorectal cancer risk. World J Gastroenterol 2009;15:2336-2339. [PubMed: 19452574]

346. Smalley W, Ray WA, Daugherty J, Griffin MR. Use of nonsteroidal anti-inflammatory drugs and incidence of colorectal cancer: a population-based study. Arch Intern Med 1999;159:161-166. [PubMed: 9927099]

347. Meyskens FL Jr, Gerner EW, Emerson S, Pelot D, Durbin T, Doyle K, Lagerberg W. Effect of alphadifluoromethylornithine on rectal mucosal levels of polyamines in a randomized, double-blinded trial for colon cancer prevention. J Natl Cancer Inst 1998;90:1212-1218. [PubMed: 9719082]

348. McLaren CE, Fujikawa-Brooks S, Chen WP, Gillen DL, Pelot D, Gerner EW, Meyskens FL Jr. Longitudinal assessment of air conduction audiograms in a phase III clinical trial of difluoromethylornithine and sulindac for prevention of sporadic colorectal adenomas. Cancer Prev Res (Phila Pa) 2008;1:514-521.

349. Zell JA, Pelot D, Chen WP, McLaren CE, Gerner EW, Meyskens FL. Risk of cardiovascular events in a randomized placebo-controlled, double-blind trial of difluoromethylornithine plus sulindac for the prevention of sporadic colorectal adenomas. Cancer Prev Res (Phila Pa) 2009;2:209-212.

350. Oshima M, Dinchuk JE, Kargman SL, Oshima H, Hancock B, Kwong E, Trzaskos JM, Evans JF, Taketo MM. Suppression of intestinal polyposis in Apc delta716 knockout mice by inhibition of cyclooxygenase 2 (COX-2). Cell 1996;87:803-809. [PubMed: 8945508]

351. Williams CS, Tsujii M, Reese J, Dey SK, DuBois RN. Host cyclooxygenase-2 modulates carcinoma growth. J Clin Invest 2000;105:1589-1594. [PubMed: 10841517]

352. Dubois RN. Review article: cyclooxygenase--a target for colon cancer prevention. Aliment Pharmacol Ther 2000;14 Suppl 1:64-67. [PubMed: 10807405]

353. Eberhart CE, Coffey RJ, Radhika A, Giardiello FM, Ferrenbach S, DuBois RN. Up-regulation of cyclooxygenase 2 gene expression in human colorectal adenomas and adenocarcinomas. Gastroenterology 1994;107:1183-1188. [PubMed: 7926468]

354. Chen LC, Hao CY, Chiu YS, Wong P, Melnick JS, Brotman M, Moretto J, Mendes F, Smith AP, Bennington JL, Moore D, Lee NM. Alteration of gene expression in normal-appearing colon mucosa of APC(min) mice and human cancer patients. Cancer Res 2004;64:3694-3700. [PubMed: 15150130]

355. Chan AT, Ogino S, Fuchs CS. Aspirin and the risk of colorectal cancer in relation to the expression of COX-2. N Engl J Med 2007;356:2131-2142. [PubMed: 17522398]

356. Barry EL, Sansbury LB, Grau MV, Ali IU, Tsang S, Munroe DJ, Ahnen DJ, Sandler RS, Saibil F, Gui J, Bresalier RS, McKeown-Eyssen GE, Burke C, Baron JA. Cyclooxygenase-2 polymorphisms, aspirin treatment, and risk for colorectal adenoma recurrence--data from a randomized clinical trial. Cancer Epidemiol Biomarkers Prev 2009;18:2726-2733. [PubMed: 19755647]

357. Kopp E, Ghosh S. Inhibition of NF-kappa B by sodium salicylate and aspirin. Science 1994;265:956959. [PubMed: 8052854]

358. Schwenger P, Bellosta P, Vietor I, Basilico C, Skolnik EY, Vilcek J. Sodium salicylate induces apoptosis via $\mathrm{p} 38$ mitogen-activated protein kinase but inhibits tumor necrosis factor-induced c-Jun N-terminal kinase/stress-activated protein kinase activation. Proc Natl Acad Sci U S A 1997;94:2869-2873. [PubMed: 9096313]

359. Martinez ME, O'Brien TG, Fultz KE, Babbar N, Yerushalmi H, Qu N, Guo Y, Boorman D, Einspahr J, Alberts DS, Gerner EW. Pronounced reduction in adenoma recurrence associated with aspirin use and a polymorphism in the ornithine decarboxylase gene. Proc Natl Acad Sci U S A 2003;100:7859-7864. [PubMed: 12810952]

360. Routine aspirin or nonsteroidal anti-inflammatory drugs for the primary prevention of colorectal cancer: U.S. Preventive Services Task Force recommendation statement. Ann Intern Med 2007;146:361-364. [PubMed: 17339621] 
361. Rostom A, Dube C, Lewin G, Tsertsvadze A, Barrowman N, Code C, Sampson M, Moher D. Nonsteroidal anti-inflammatory drugs and cyclooxygenase-2 inhibitors for primary prevention of colorectal cancer: a systematic review prepared for the U.S. Preventive Services Task Force. Ann Intern Med 2007;146:376-389. [PubMed: 17339623]

362. Bardia A, Ebbert JO, Vierkant RA, Limburg PJ, Anderson K, Wang AH, Olson JE, Vachon CM, Cerhan JR. Association of aspirin and nonaspirin nonsteroidal anti-inflammatory drugs with cancer incidence and mortality. J Natl Cancer Inst 2007;99:881-889. [PubMed: 17551148]

363. Chan AT, Manson JE, Albert CM, Chae CU, Rexrode KM, Curhan GC, Rimm EB, Willett WC, Fuchs CS. Nonsteroidal antiinflammatory drugs, acetaminophen, and the risk of cardiovascular events. Circulation 2006;113:1578-1587. [PubMed: 16534006]

364. Limburg PJ, Cerhan JR. Aspirin chemoprevention for colorectal cancer: helpful, harmful, or still too soon to tell? Gastroenterology 2007;133:717-718. [PubMed: 17681190]

365. Dube C, Rostom A, Lewin G, Tsertsvadze A, Barrowman N, Code C, Sampson M, Moher D. The use of aspirin for primary prevention of colorectal cancer: a systematic review prepared for the U.S. Preventive Services Task Force. Ann Intern Med 2007;146:365-375. [PubMed: 17339622]

366. Cuzick J, Otto F, Baron JA, Brown PH, Burn J, Greenwald P, Jankowski J, La Vecchia C, Meyskens F, Senn HJ, Thun M. Aspirin and non-steroidal anti-inflammatory drugs for cancer prevention: an international consensus statement. Lancet Oncol 2009;10:501-507. [PubMed: 19410194]

367. Chan AT, Ogino S, Fuchs CS. Aspirin use and survival after diagnosis of colorectal cancer. JAMA 2009;302:649-658. [PubMed: 19671906]

368. Zell JA, Ziogas A, Bernstein L, Clarke CA, Deapen D, Largent JA, Neuhausen SL, Stram DO, Ursin $\mathrm{G}$, Anton-Culver H. Nonsteroidal anti-inflammatory drugs: effects on mortality after colorectal cancer diagnosis. Cancer. 2009

369. Dornschneider G, Izbicki JR, Wilker DK, Schweiberer L. The effects of sex steroids on colon carcinogenesis. Anticancer Drugs 1990;1:15-21. [PubMed: 2131030]

370. McMichael AJ, Potter JD. Host factors in carcinogenesis: certain bile-acid metabolic profiles that selectively increase the risk of proximal colon cancer. J Natl Cancer Inst 1985;75:185-191. [PubMed: 3894750]

371. Lampe JW, Fredstrom SB, Slavin JL, Potter JD. Sex differences in colonic function: a randomised trial. Gut 1993;34:531-536. [PubMed: 8387940]

372. Campagnoli C, Biglia N, Altare F, Lanza MG, Lesca L, Cantamessa C, Peris C, Fiorucci GC, Sismondi P. Differential effects of oral conjugated estrogens and transdermal estradiol on insulinlike growth factor 1, growth hormone and sex hormone binding globulin serum levels. Gynecol Endocrinol 1993;7:251-258. [PubMed: 8147234]

373. Issa JP, Ottaviano YL, Celano P, Hamilton SR, Davidson NE, Baylin SB. Methylation of the oestrogen receptor CpG island links ageing and neoplasia in human colon. Nat Genet 1994;7:536540. [PubMed: 7951326]

374. Risch HA, Howe GR. Menopausal hormone use and colorectal cancer in Saskatchewan: a record linkage cohort study. Cancer Epidemiol Biomarkers Prev 1995;4:21-28. [PubMed: 7894320]

375. Troisi R, Schairer C, Chow WH, Schatzkin A, Brinton LA, Fraumeni JF Jr. A prospective study of menopausal hormones and risk of colorectal cancer (United States). Cancer Causes Control 1997;8:130-138. [PubMed: 9134236]

376. Weiss NS, Daling JR, Chow WH. Incidence of cancer of the large bowel in women in relation to reproductive and hormonal factors. J Natl Cancer Inst 1981;67:57-60. [PubMed: 6942196]

377. Calle EE, Miracle-McMahill HL, Thun MJ, Heath CW Jr. Estrogen replacement therapy and risk of fatal colon cancer in a prospective cohort of postmenopausal women. J Natl Cancer Inst 1995;87:517-523. [PubMed: 7707438]

378. Corrao G, Zambon A, Conti V, Nicotra F, La Vecchia C, Fornari C, Cesana G, Contiero P, Tagliabue G, Nappi RE, Merlino L. Menopause hormone replacement therapy and cancer risk: an Italian record linkage investigation. Ann Oncol 2008;19:150-155. [PubMed: 17785762]

379. Fernandez E, La Vecchia C, Braga C, Talamini R, Negri E, Parazzini F, Franceschi S. Hormone replacement therapy and risk of colon and rectal cancer. Cancer Epidemiol Biomarkers Prev 1998;7:329-333. [PubMed: 9568789] 
380. Folsom AR, Mink PJ, Sellers TA, Hong CP, Zheng W, Potter JD. Hormonal replacement therapy and morbidity and mortality in a prospective study of postmenopausal women. Am J Public Health 1995;85:1128-1132. [PubMed: 7625511]

381. Furner SE, Davis FG, Nelson RL, Haenszel W. A case-control study of large bowel cancer and hormone exposure in women. Cancer Res 1989;49:4936-4940. [PubMed: 2758422]

382. Hammond CB, Jelovsek FR, Lee KL, Creasman WT, Parker RT. Effects of long-term estrogen replacement therapy. II. Neoplasia. Am J Obstet Gynecol 1979;133:537-547. [PubMed: 220875]

383. Jacobs EJ, White E, Weiss NS. Exogenous hormones, reproductive history, and colon cancer (Seattle, Washington, USA). Cancer Causes Control 1994;5:359-366. [PubMed: 8080948]

384. Johnson JR, Lacey JV Jr, Lazovich D, Geller MA, Schairer C, Schatzkin A, Flood A. Menopausal hormone therapy and risk of colorectal cancer. Cancer Epidemiol Biomarkers Prev 2009;18:196203. [PubMed: 19124498]

385. Kampman E, Potter JD, Slattery ML, Caan BJ, Edwards S. Hormone replacement therapy, reproductive history, and colon cancer: a multicenter, case-control study in the United States. Cancer Causes Control 1997;8:146-158. [PubMed: 9134238]

386. Nachtigall LE, Nachtigall RH, Nachtigall RD, Beckman EM. Estrogen replacement therapy II: a prospective study in the relationship to carcinoma and cardiovascular and metabolic problems. Obstet Gynecol 1979;54:74-79. [PubMed: 221871]

387. Paganini-Hill A. Estrogen replacement therapy and colorectal cancer risk in elderly women. Dis Colon Rectum 1999;42:1300-1305. [PubMed: 10528768]

388. Persson I, Yuen J, Bergkvist L, Schairer C. Cancer incidence and mortality in women receiving estrogen and estrogen-progestin replacement therapy--long-term follow-up of a Swedish cohort. Int J Cancer 1996;67:327-332. [PubMed: 8707404]

389. Peters RK, Pike MC, Chang WW, Mack TM. Reproductive factors and colon cancers. Br J Cancer 1990;61:741-748. [PubMed: 2337511]

390. Potter JD, McMichael AJ. Large bowel cancer in women in relation to reproductive and hormonal factors: a case-control study. J Natl Cancer Inst 1983;71:703-709. [PubMed: 6578365]

391. Prihartono N, Palmer JR, Louik C, Shapiro S, Rosenberg L. A case-control study of use of postmenopausal female hormone supplements in relation to the risk of large bowel cancer. Cancer Epidemiol Biomarkers Prev 2000;9:443-447. [PubMed: 10794491]

392. Rennert G, Rennert HS, Pinchev M, Lavie O, Gruber SB. Use of hormone replacement therapy and the risk of colorectal cancer. J Clin Oncol 2009;27:4542-4547. [PubMed: 19704062]

393. Slattery ML, Potter JD, Curtin K, Edwards S, Ma KN, Anderson K, Schaffer D, Samowitz WS. Estrogens reduce and withdrawal of estrogens increase risk of microsatellite instability-positive colon cancer. Cancer Res 2001;61:126-1230. [PubMed: 11196149]

394. Jacobson JS, Neugut AI, Garbowski GC, Ahsan H, Waye JD, Treat MR, Forde KA. Reproductive risk factors for colorectal adenomatous polyps (New York City, NY, United States). Cancer Causes Control 1995;6:513-518. [PubMed: 8580299]

395. Peipins LA, Newman B, Sandler RS. Reproductive history, use of exogenous hormones, and risk of colorectal adenomas. Cancer Epidemiol Biomarkers Prev 1997;6:671-675. [PubMed: 9298573]

396. Potter JD, Bostick RM, Grandits GA, Fosdick L, Elmer P, Wood J, Grambsch P, Louis TA. Hormone replacement therapy is associated with lower risk of adenomatous polyps of the large bowel: the Minnesota Cancer Prevention Research Unit Case-Control Study. Cancer Epidemiol Biomarkers Prev 1996;5:779-784. [PubMed: 8896888]

397. Wolf LA, Terry PD, Potter JD, Bostick RM. Do factors related to endogenous and exogenous estrogens modify the relationship between obesity and risk of colorectal adenomas in women? Cancer Epidemiol Biomarkers Prev 2007;16:676-683. [PubMed: 17416757]

398. Woodson K, Lanza E, Tangrea JA, Albert PS, Slattery M, Pinsky J, Caan B, Paskett E, Iber F, Kikendall JW, Lance P, Shike M, Weissfeld J, Schatzkin A. Hormone replacement therapy and colorectal adenoma recurrence among women in the Polyp Prevention Trial. J Natl Cancer Inst 2001;93:1799-1805. [PubMed: 11734596]

399. Grodstein F, Martinez ME, Platz EA, Giovannucci E, Colditz GA, Kautzky M, Fuchs C, Stampfer MJ. Postmenopausal hormone use and risk for colorectal cancer and adenoma. Ann Intern Med 1998;128:705-712. [PubMed: 9556463] 
400. Grodstein F, Newcomb PA, Stampfer MJ. Postmenopausal hormone therapy and the risk of colorectal cancer: a review and meta-analysis. Am J Med 1999;106:574-582. [PubMed: 10335731]

401. Hebert-Croteau N. A meta-analysis of hormone replacement therapy and colon cancer in women. Cancer Epidemiol Biomarkers Prev 1998;7:653-659. [PubMed: 9718216]

402. Rossouw JE, Anderson GL, Prentice RL, LaCroix AZ, Kooperberg C, Stefanick ML, Jackson RD, Beresford SA, Howard BV, Johnson KC, Kotchen JM, Ockene J. Risks and benefits of estrogen plus progestin in healthy postmenopausal women: principal results from the Women's Health Initiative randomized controlled trial. JAMA 2002;288:321-333. [PubMed: 12117397]

403. Ritenbaugh C, Stanford JL, Wu L, Shikany JM, Schoen RE, Stefanick ML, Taylor V, Garland C, Frank G, Lane D, Mason E, McNeeley SG, Ascensao J, Chlebowski RT. Conjugated equine estrogens and colorectal cancer incidence and survival: the Women's Health Initiative randomized clinical trial. Cancer Epidemiol Biomarkers Prev 2008;17:2609-2618. [PubMed: 18829444]

404. Newcomb PA, Zheng Y, Chia VM, Morimoto LM, Doria-Rose VP, Templeton A, Thibodeau SN, Potter JD. Estrogen plus progestin use, microsatellite instability, and the risk of colorectal cancer in women. Cancer Res 2007;67:7534-7539. [PubMed: 17671225]

405. Tannen RL, Weiner MG, Xie D, Barnhart K. Estrogen affects post-menopausal women differently than estrogen plus progestin replacement therapy. Hum Reprod 2007;22:1769-1777. [PubMed: 17347166]

406. Hildebrand JS, Jacobs EJ, Campbell PT, McCullough ML, Teras LR, Thun MJ, Gapstur SM. Colorectal Cancer Incidence and Postmenopausal Hormone Use by Type, Recency, and Duration in Cancer Prevention Study II. Cancer Epidemiol Biomarkers Prev. 2009

407. Prentice RL, Pettinger M, Beresford SA, Wactawski-Wende J, Hubbell FA, Stefanick ML, Chlebowski RT. Colorectal cancer in relation to postmenopausal estrogen and estrogen plus progestin in the Women's Health Initiative clinical trial and observational study. Cancer Epidemiol Biomarkers Prev 2009;18:1531-1537. [PubMed: 19423530]

408. Platz EA, Willett WC, Colditz GA, Rimm EB, Spiegelman D, Giovannucci E. Proportion of colon cancer risk that might be preventable in a cohort of middle-aged US men. Cancer Causes Control 2000;11:579-588. [PubMed: 10977102]

409. Parkin DM, Olsen AH, Sasieni P. The potential for prevention of colorectal cancer in the UK. Eur J Cancer Prev 2009;18:179-190. [PubMed: 19238085]

410. Wei EK, Colditz GA, Giovannucci EL, Fuchs CS, Rosner BA. Cumulative risk of colon cancer up to age 70 years by risk factor status using data from the Nurses' Health Study. American Journal of Epidemiology 2009;170:863-872. [PubMed: 19723749]

411. Pai R, Soreghan B, Szabo IL, Pavelka M, Baatar D, Tarnawski AS. Prostaglandin E2 transactivates EGF receptor: a novel mechanism for promoting colon cancer growth and gastrointestinal hypertrophy. Nat Med 2002;8:289-293. [PubMed: 11875501]

412. He TC, Chan TA, Vogelstein B, Kinzler KW. PPARdelta is an APC-regulated target of nonsteroidal anti-inflammatory drugs. Cell 1999;99:335-345. [PubMed: 10555149]

413. Lehmann JM, Lenhard JM, Oliver BB, Ringold GM, Kliewer SA. Peroxisome proliferator-activated receptors alpha and gamma are activated by indomethacin and other non-steroidal antiinflammatory drugs. J Biol Chem 1997;272:3406-3410. [PubMed: 9013583]

414. Hsu AL, Ching TT, Wang DS, Song X, Rangnekar VM, Chen CS. The cyclooxygenase-2 inhibitor celecoxib induces apoptosis by blocking Akt activation in human prostate cancer cells independently of Bcl-2. J Biol Chem 2000;275:11397-11403. [PubMed: 10753955]

415. Myung SJ, Rerko RM, Yan M, Platzer P, Guda K, Dotson A, Lawrence E, Dannenberg AJ, Lovgren AK, Luo G, Pretlow TP, Newman RA, Willis J, Dawson D, Markowitz SD. 15Hydroxyprostaglandin dehydrogenase is an in vivo suppressor of colon tumorigenesis. Proc Natl Acad Sci U S A 2006;103:12098-12102. [PubMed: 16880406]

416. Yan M, Myung SJ, Fink SP, Lawrence E, Lutterbaugh J, Yang P, Zhou X, Liu D, Rerko RM, Willis J, Dawson D, Tai HH, Barnholtz-Sloan JS, Newman RA, Bertagnolli MM, Markowitz SD. 15Hydroxyprostaglandin dehydrogenase inactivation as a mechanism of resistance to celecoxib chemoprevention of colon tumors. Proc Natl Acad Sci U S A 2009;106:9409-9413. [PubMed: 19470469] 
417. Yan M, Rerko RM, Platzer P, Dawson D, Willis J, Tong M, Lawrence E, Lutterbaugh J, Lu S, Willson JK, Luo G, Hensold J, Tai HH, Wilson K, Markowitz SD. 15-Hydroxyprostaglandin dehydrogenase, a COX-2 oncogene antagonist, is a TGF-beta-induced suppressor of human gastrointestinal cancers. Proc Natl Acad Sci U S A 2004;101:17468-17473. [PubMed: 15574495]

418. Cai Q, Gao YT, Chow WH, Shu XO, Yang G, Ji BT, Wen W, Rothman N, Li HL, Morrow JD, Zheng W. Prospective study of urinary prostaglandin E2 metabolite and colorectal cancer risk. J Clin Oncol 2006;24:5010-5016. [PubMed: 17075120]

419. Chen J, Giovannucci EL, Hunter DJ. MTHFR polymorphism, methyl-replete diets and the risk of colorectal carcinoma and adenoma among U.S. men and women: an example of gene-environment interactions in colorectal tumorigenesis. J Nutr 1999;129 560S-564S.

\section{Biographies}

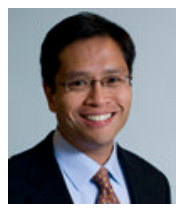




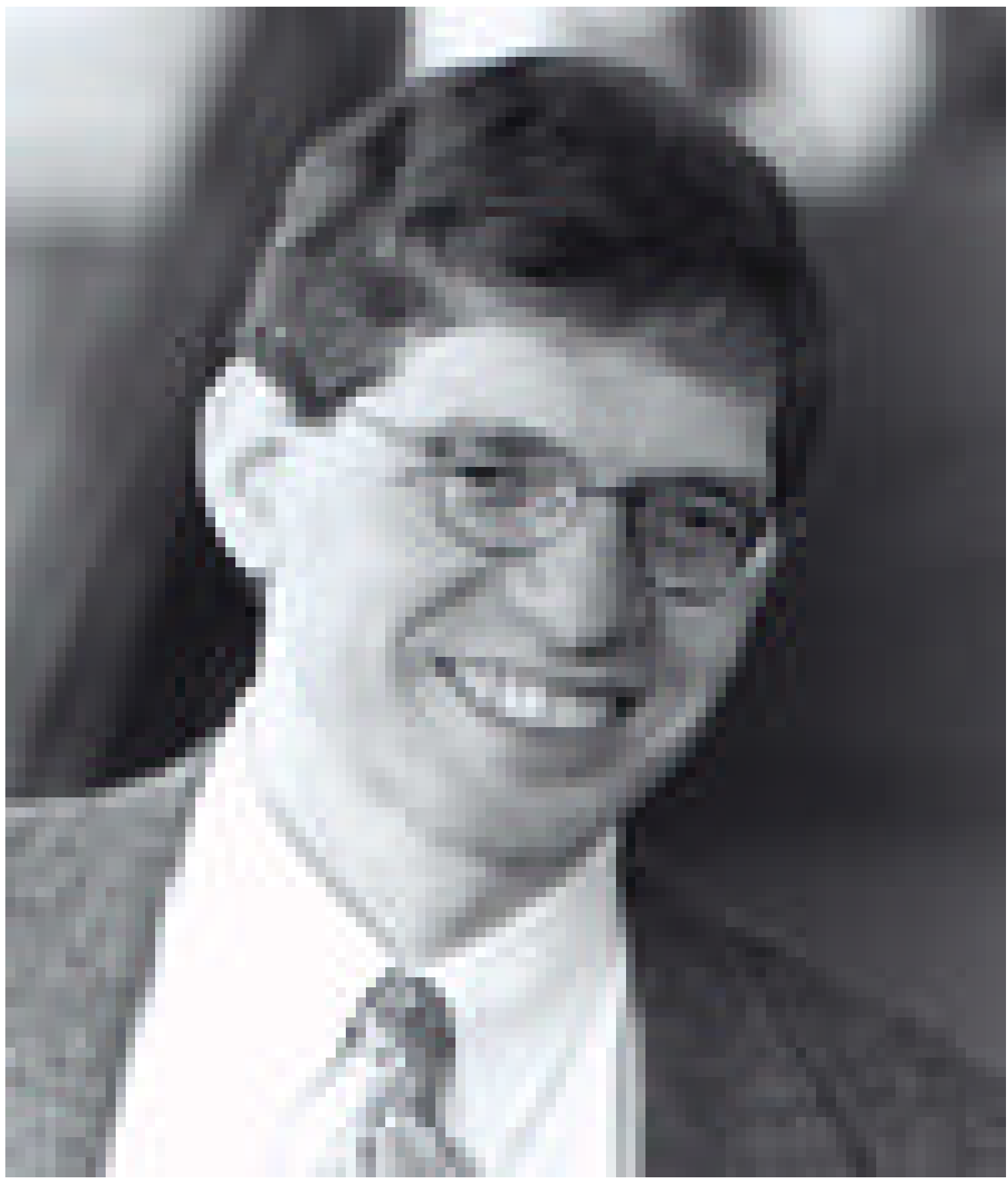




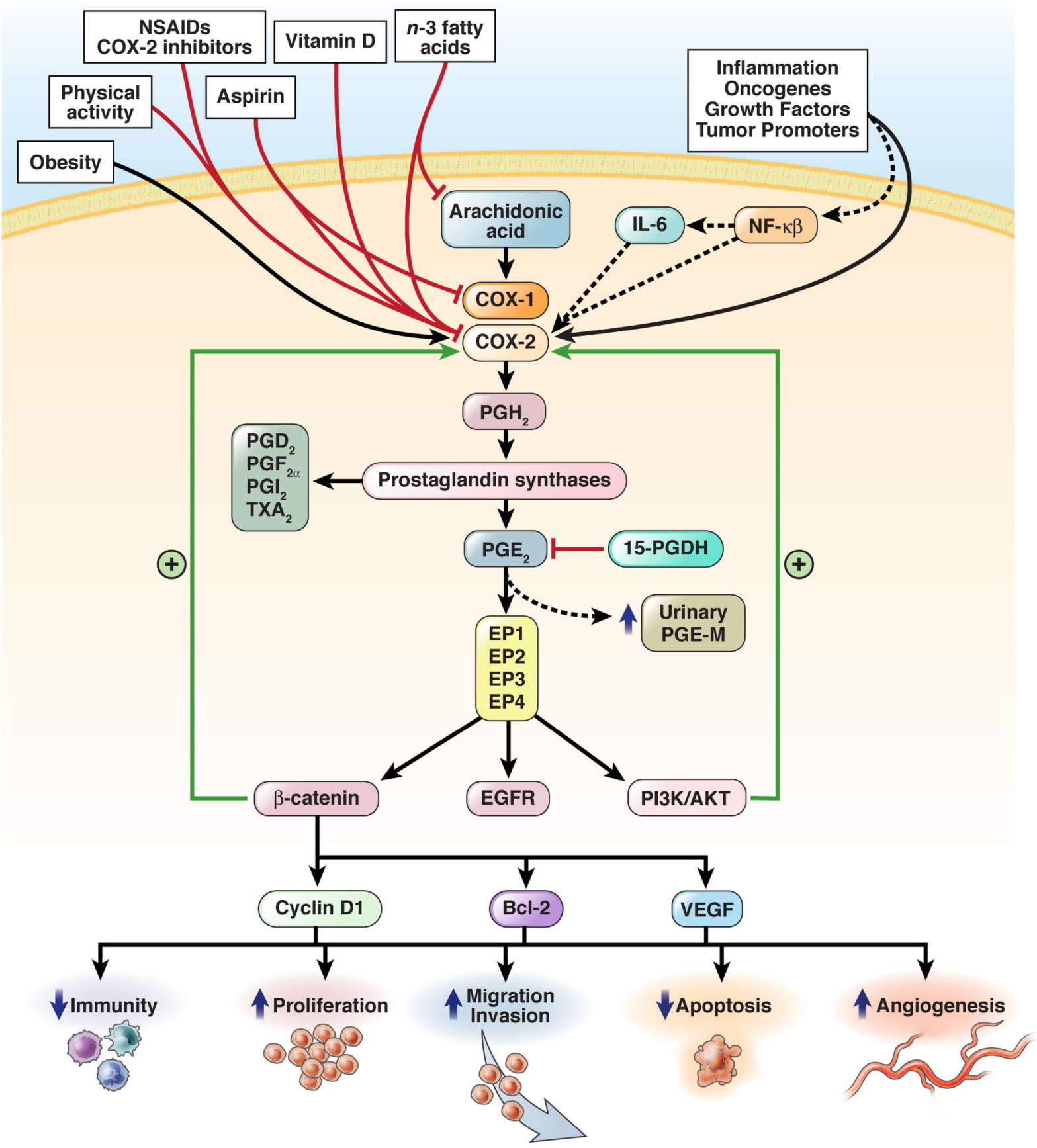

Figure 1. Proposed insulin-related mechanisms that relate diet, obesity, and physical activity to colorectal cancer

Abdominal obesity, physical inactivity, and some aspects of a Western diet that stimulate insulin secretion could increase risk of colorectal cancer by causing repeated bouts of hyperinsulinemia. High levels of insulin might have direct effects on susceptible cells through insulin receptors or through IGF-1 receptors by decreasing IGF binding proteins thereby increasing free levels of IGF-1. Activation of insulin and IGF-1 receptors might lead to increased cell proliferation and reduced apoptosis, which could increase the risk tumorigenesis. 248 


\section{Physical inactivity Abdominal obesity}

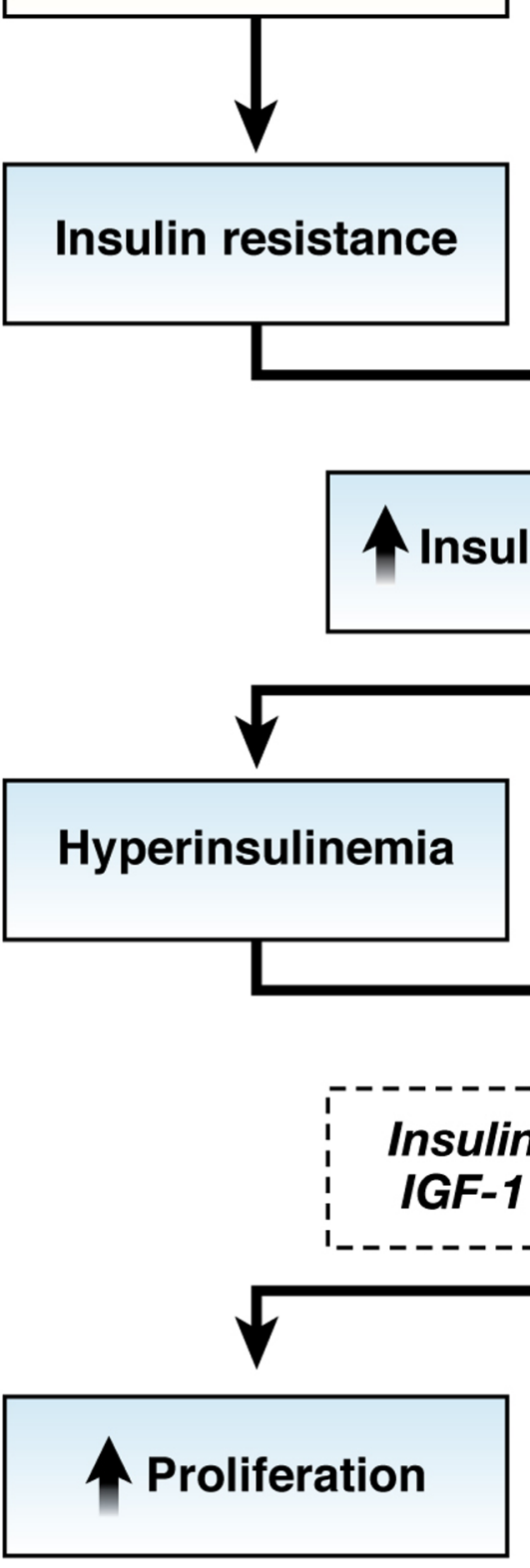

Red \& processed meats, saturated fats, sweets, refined grains

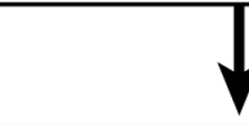

Competent pancreatic $\beta$-cells

Figure 2. Proposed inflammatory mechanisms relating diet, lifestyle, and medication use to colorectal cancer

Dietary components (e.g. vitamin D and $n-3$ fatty acids), lifestyle factors (e.g. physical activity), and medications (e.g. aspirin, COX-2 inhibitors, NSAIDs), might have anticancer effects (red lines) whereas lifestyle factors such as obesity could promote cancer (black lines) through anti-inflammatory mechanisms that are largely mediated through inhibition of the COX-2 enzyme. COX-2 could be upregulated by inflammatory or oncogenic stimuli via inflammatory cytokines such as or interleukin-6 (IL-6) or others that induce nuclear factor $\kappa \mathrm{B}$ $(\mathrm{NF}-\kappa \mathrm{B})$. COX-2 converts membrane-associated arachidonic acid to prostaglandins, including $\mathrm{PGH}_{2}, \mathrm{PGD}_{2}, \mathrm{PGF}_{\alpha}, \mathrm{PGI}_{2}$ (prostacyclin), and thromboxane A2, as well as $\mathrm{PGE}_{2}$. In turn, 
$\mathrm{PGE}_{2}$ stimulates EP2, which upregulates transcriptional activity of $\beta$-catenin and activates the oncogene products phosphatidylinositol-3-kinase (PI3K) and the kinase AKT. $\mathrm{PGE}_{2}$ also stimulates EP4, which triggers phosphorylation of the epidermal growth factor receptor (EGFR), ${ }^{411}$ thereby activating PI3K, AKT, and the oncogenic RAS-mitogen-activated protein kinase (MAPK) cascade. $\mathrm{PGE}_{2}$ stimulation of PI3K signaling also activates the transcriptional activity of the peroxisome-proliferator-activated receptor $\delta$ (PPAR $\delta$ ). These $\mathrm{PGE}_{2}$-induced signaling pathways induce expression of a number of genes, including the angiogenic factor vascular endothelial growth factor (VEGF), the anti-apoptotic factor Bcl-2, and the proliferation-promoting factor cyclin D1. Many of the downstream targets of $\mathrm{PGE}_{2}$ act in positive feedback loops to induce greater expression of COX-2 (green arrows). Aspirin and NSAIDs might also directly stimulate PPARs412, 413 and block phosphorylation of AKT. 414 15-prostaglandin dehydrogenase (15-PGDH) inhibits PGE $_{2}$ and thereby functions as a prostaglandin-degrading enzyme. $415^{-417}$ Upregulation of prostaglandin synthesis increases urinary $11 \alpha$-hydroxy-9,15-dioxo-2,3,4,5-tetranor-prostane-1,20-dioic acid (PGE-M), the major metabolite of $\mathrm{PGE}_{2} .418$ 


\section{High folate/low alcohol:}
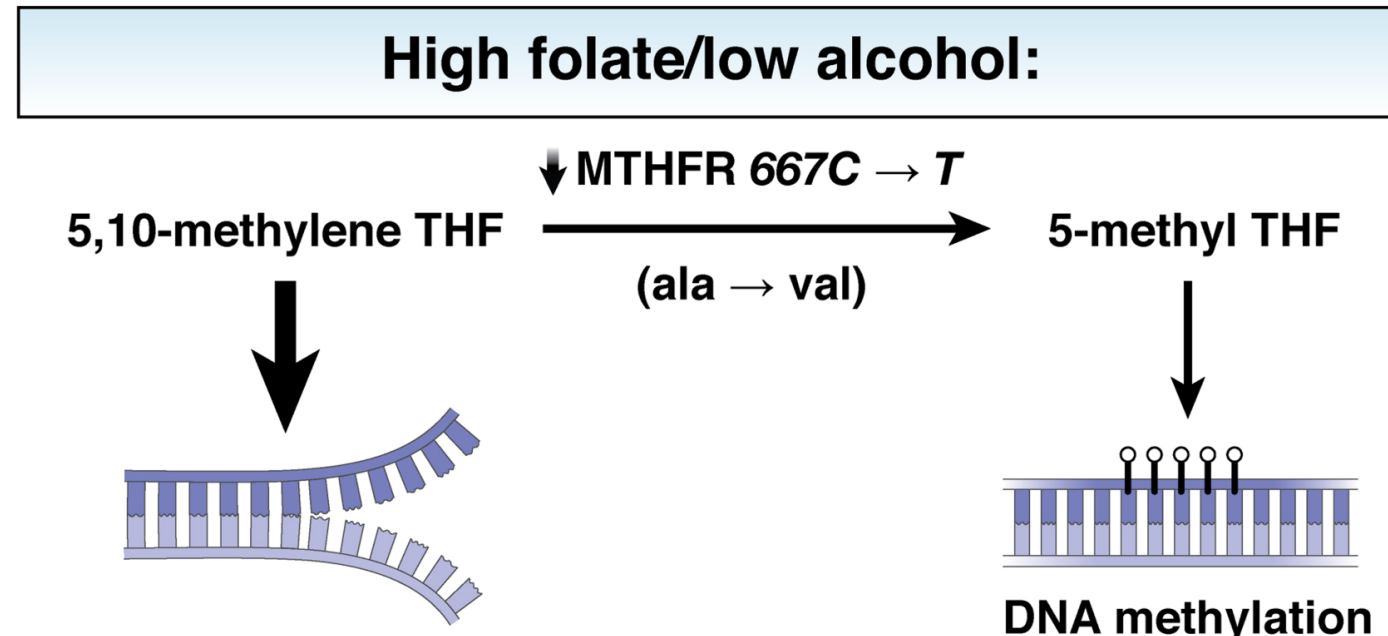
DNA synthesis
( $\forall$ uracil misincorporation into DNA)
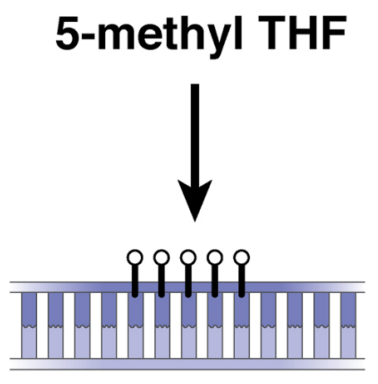

DNA methylation

\section{Low folate/high alcohol:}

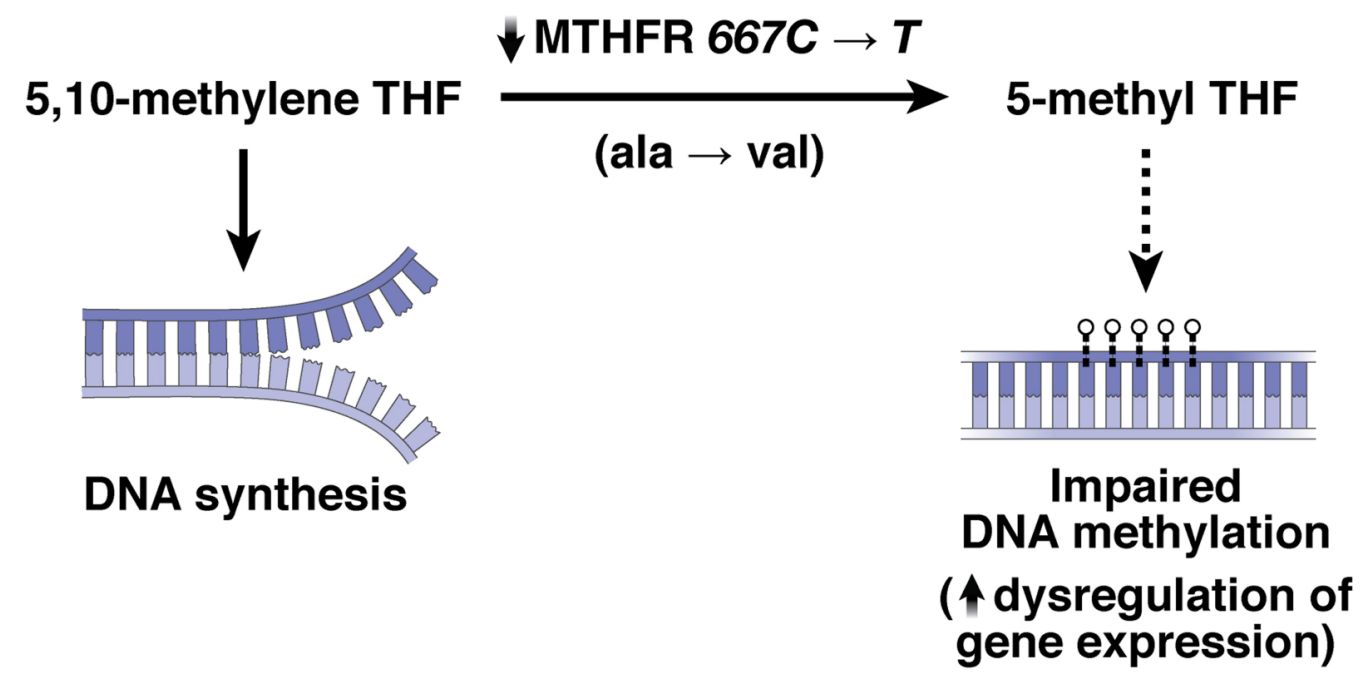

Figure 3. Proposed mechanism relating folate, alcohol, $M T H F R$ genotype, and colorectal cancer (THIS FIGURE IS BEING PREPARED BY ILLUSTRATOR) The TT genotype of MTHFR is associated with impaired function of the MTHFR enzyme in converting 5,10-methylene tetrahydrofolate (THF) into 5-methyl THF. For individuals with $C C$ or $C T$ genotypes, only modest associations are observed between folate, alcohol, and risk of colorectal neoplasia. However, individuals with the $T T$ genotype might be particularly sensitive to the anti-cancer effects of high folate intake and low alcohol consumption. Specifically, with high stores of folate, the higher levels of 5,10-methyl THR might prevent imbalances of nucleotide pools during DNA synthesis (e.g. reduced uracil misincorporation) and a sufficient amount of 5,10methylene THF is converted to 5-methyl THF for DNA methylation. In contrast, when the 
methyl content in the diet is low or depleted by alcohol consumption, individuals with TT genotypes might be less able to compensate for the impairment in MTHFR function; therefore, these individuals are less able to produce sufficient amounts of 5-methyl THF for DNA methylation. Impairment of DNA methylation processes results in dysregulation of gene expression. $^{419}$ 


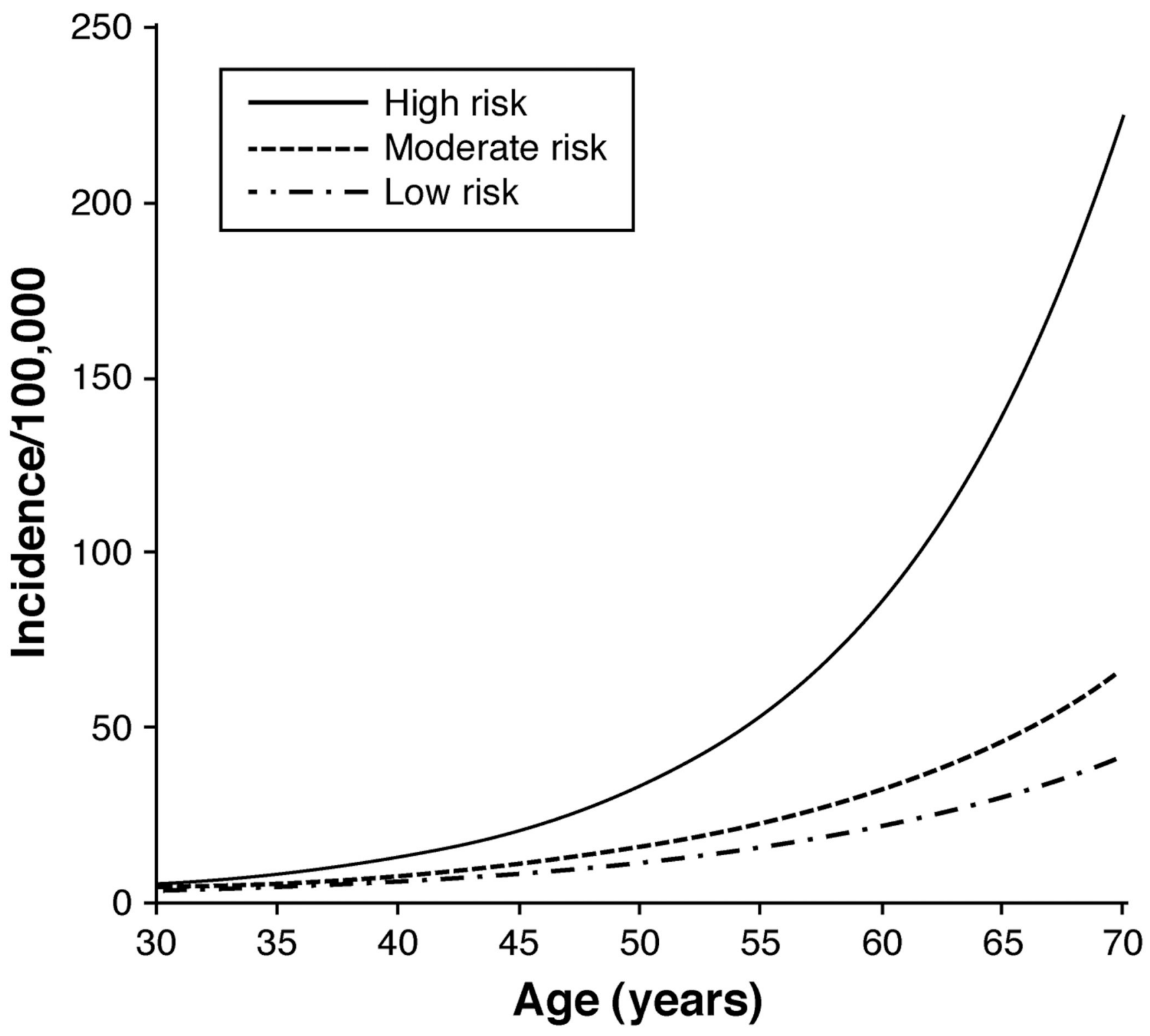

Figure 4. Age-specific incidence of colon cancer per 100,000 person-years according to modifiable risk factors

Women were enrolled in the Nurses' Health Study and were followed between 1980 and 2004. Women were assumed to have no postmenopausal hormone use, no aspirin use, average height, no family history of colorectal cancer, and have never been screened for colorectal cancer. 1) a "high-risk" participant (one who accrued 10 pack-years of smoking before age 30 years, had a consistently high relative body weight, had physical activity of 2 metabolic equivalent (MET)-hours/week, consumed 1 serving of red or processed meat per day, and had a folate intake of $150 \mu \mathrm{g} /$ day); 2) a "moderate-risk" participant (one who was a nonsmoker, had an average body mass index, had physical activity of 13.5 MET-hours/week, did not consume red or processed meat, and had a folate intake of $300 \mu \mathrm{g} / \mathrm{day}$ ); and 3) a "low-risk" participant (one who was a nonsmoker, had a consistently low relative body weight, had physical activity of 21 MET-hours/week, did not consume red or processed meat, and had a folate intake of 400 $\mu \mathrm{g} /$ day). Taken from Wei et al. ${ }^{410}$ 


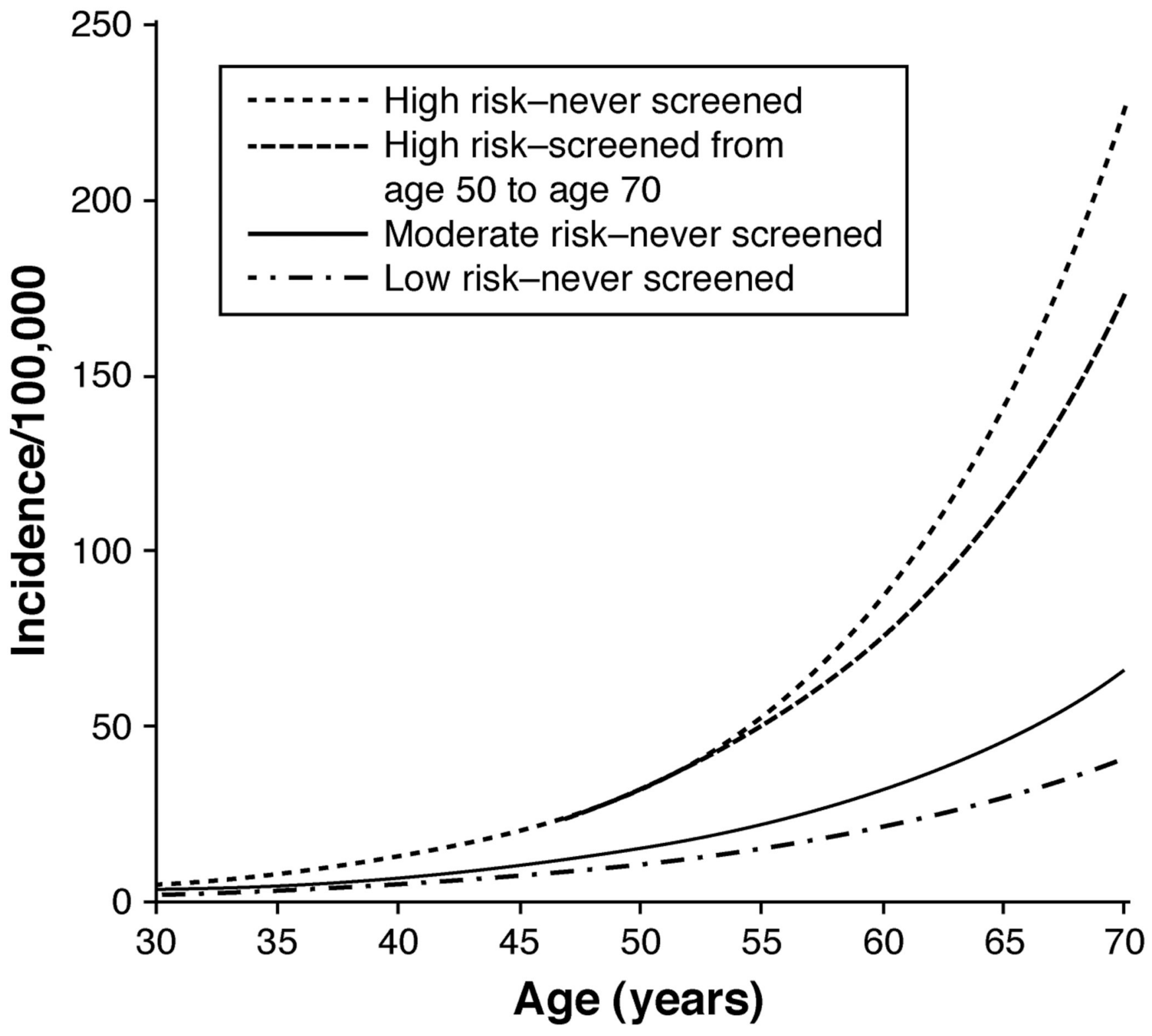

Figure 5. Age-specific incidence of colon cancer per 100,000 person-years according to modifiable risk factors and screening behavior

Women were enrolled in the Nurses' Health Study and were followed between 1980 and 2004. Women were assumed to have no postmenopausal hormone use, no aspirin use, average height, no family history of colorectal cancer, and have never been screened for colorectal cancer. 1) a high-risk" participant (one who accrued 10 pack-years of smoking before age 30 years, had a consistently high relative body weight, had physical activity of 2 metabolicMET)-hours/ week, consumed 1 serving of red or processed meat per day, was never screened for colon cancer, and had a folate intake of $150 \mu \mathrm{g}$ /day); 2) a high-risk participant who was screened from age 50 years to age 70 years; 3 ) a "moderate-risk" participant (one who was a nonsmoker, had an average body mass index, had physical activity of 13.5 MET-hours/week, did not consume red or processed meat, was never screened, and had a folate intake of $300 \mu \mathrm{g} / \mathrm{day}$ ); and 4) a "low-risk" participant (one who was a nonsmoker, had a consistently low relative body 
weight, had physical activity of 21 MET-hours/week, did not consume red or processed meat, was never screened, and had a folate intake of $400 \mu \mathrm{g} /$ day). Taken from Wei et al. ${ }^{410}$ 